\title{
The Asset Management Industry in Asia: Dynamics of Growth, Structure and Performance
}

\author{
Ingo Walter and Elif Sisli \\ Stern School of Business, New York University, New York, NY 10012, USA
}

\begin{abstract}
We examine the industrial organization and institutional development of the asset management industry in Asian developing economies - specifically in China, Indonesia, Korea, Malaysia, Singapore, Philippines and Thailand. We focus on the size and growth of the buy-side of the respective financial markets, asset allocation, the regulatory environment, and the state of internationalization of the fund management industry in its key components - mutual funds, pension funds and asset management for high net worth individuals. We link these the evolution of professional asset management in these environments to the development of the respective capital markets and to the evolution of corporate governance. We find that the fund management industry occupies a very small niche in domestic financial systems that are dominated by banks. At the same time, we find that its growth has been very rapid in the early 2000 s and we suggest that this is likely to persist as the demand for professional management of financial wealth in the region develops and as the pension fund sectors of the respective economies are liberalized to allow larger portions of assets to be invested in collective investment schemes.
\end{abstract}

Keywords: Asset management, Asia financial systems, pension funds, mutual funds, private banking

JEL Classification: G23, O16

*We are grateful to the Office Of Regional Economic Integration, Asian Development Bank and the members of the ASEAN+3 Research Group meeting in Seoul, Korea in February 2006 for research support and comments on this paper, respectively. All errors are our own. 
Few industries have encountered as much 'strategic turbulence' in recent years as has the financial services sector. In response to far-reaching regulatory and technological change, together with important shifts in client behavior and the globalization of specific financial functions, the organizational structure of the industry has been profoundly displaced, and there remains a great deal of uncertainly about the nature of any future equilibrium in the industry's contours. This applies to financial services in general and to asset management - the "buy-side" of the capital markets in particular. Moreover, there is ample evidence to suggest that the development of the asset management industry has much to do with the static and dynamic efficiency of financial intermediation in national and global financial systems. Asset gathering and deployment of savings bear on the rate of capital formation and the growth process in general.

This study focuses on the development of the asset management industry in key economies of Asia - specifically in China, Indonesia, Korea, Malaysia, Singapore, Philippines and Thailand. We begin with a generic discussion of asset management and fiduciary functions in the financial intermediation process, including its institutional and industrial organization dimensions. It proceeds to review available information on the overall financial market structure and financial infrastructures in East Asian countries as they pertain to the asset management industry, and identifies key issues and challenges in financial intermediation as they bear on economic growth. To the extent permitted by data availability, the paper analyzes the historical growth and current state of the asset management industry in selected countries in the region, and identifies key impediments to its development. Finally, it considers selected policy measures that may help develop the asset management industry in Asia, including establishment of market infrastructures and sensible legal and supervisory frameworks.

\section{Financial Intermediation Dynamics}

The central component of any model of a modern financial system is the nature of the conduits through which the financial assets of the ultimate savers flow -through to the liabilities of the ultimate users of finance, both within and between national economies. [Smith and Walter, 2003] This involves alternative and competing modes of financial intermediation, or "contracting", between counterparties in financial transactions. A guide to thinking about financial contracting and the role of financial institutions and markets is summarized in Exhibit $1 .{ }^{1}$ The diagram depicts the financial process (flow-of-funds) among the different sectors of the economy in terms of underlying environmental and regulatory determinants or drivers as well as the generic advantages needed to profit from three primary linkages:

- Fully intermediated financial flows. Savings (the ultimate sources of funds in financial systems) may be held in the form of deposits or alternative types of

\footnotetext{
${ }^{1}$ For an early version, see Walter (1988).
} 
claims issued by commercial banks, savings organizations, insurance companies or other types of financial institutions that finance themselves by placing their liabilities directly with the general public. Financial institutions ultimately use these funds to purchase assets issued by non-financial entities such as households, firms and governments.

- Investment banking and securitized intermediation. Savings may be allocated directly or indirectly, via fiduciaries and collective investment vehicles, to the purchase of securities publicly issued and sold by various pubic- and privatesector organizations in the domestic and international financial markets.

- Direct-connect mechanisms between ultimate borrowers and lenders. Savings surpluses may be allocated to borrowers through various kinds of direct-sale mechanisms, such as private placements, usually involving fiduciaries as intermediaries.

Ultimate users of funds comprise the same three segments of the economy the household or consumer sector, the business sector and the government sector.

- Consumers may finance purchases by means of personal loans from banks or by loans secured by purchased assets (hire-purchase or installment loans). These may appear on the asset side of the balance sheets of credit institutions for the duration of the respective loan contracts on a revolving basis, or they may be sold off into the financial market in the form various kinds of securities backed by consumer credit receivables.

- Corporations may borrow from banks in the form of unsecured or asset-backed straight or revolving credit facilities and/or may sell debt obligations (for example commercial paper, receivables financing, fixed-income securities of various types) or equities directly into the financial market.

- Governments may likewise borrow from credit institutions (sovereign borrowing) or issue securities directly.

Borrowers such as corporations and governments also have the possibility of privately issuing and placing their obligations with institutional investors, thereby circumventing both credit institutions and the public debt and equity markets.

In the first mode of financial contracting in Exhibit 1, depositors buy the "secondary" financial claims or liabilities issued by credit institutions, and benefit from liquidity, convenience, and safety through the ability of financial institutions to diversify risk and improve credit quality by means of professional management and monitoring of their holdings of primary financial claims (both debt and equity). Savers can choose from among a set of standardized contracts and receive payments services and 
interest.

In the second mode of financial intermediation in Exhibit 1, investors can select their own portfolios of financial assets directly from among the publicly issued debt and equity instruments on offer. This may provide a broader range of options than standardized bank contracts, and permit the larger investors to tailor portfolios more closely to their objectives while still achieving acceptable liquidity through rapid and cheap execution of trades - aided by linkages with banks and other financial institutions that are part of the domestic payments mechanism. Investors may also choose to have their portfolios professionally managed, for a fee, through various types of mutual funds and pension funds - designated in Exhibit 1 as "collective investment vehicles."

In the third mode of financial intermediation, asset managers in the form of institutional investors buy large blocks of privately issued securities. In doing so, they often face a liquidity penalty - due to the absence or limited availability of a liquid secondary market - for which they are rewarded by a higher yield. On the other hand, directly placed securities can be specifically "tailored" to more closely match issuer and investor requirements than can publicly issued securities. Market and regulatory developments (such as SEC Rule 144A in the US) have added to the liquidity of some direct-placement markets.

Value to ultimate savers and investors, inherent in the financial processes described here, accrues in the form of a combination of yield, safety and liquidity. Value to ultimate users of funds accrues in the form of a combination of financing cost, transactions cost, flexibility and liquidity. This value can be enhanced through credit backstops, guarantees and derivative instruments such as forward rate agreements, caps, collars, futures and options. Furthermore, markets can be linked functionally and geographically, both domestically and internationally. Functional linkages permit bank receivables, for example, to be repackaged and sold to non-bank securities investors. Privately placed securities, once they have been seasoned, may be able to be sold in public markets. Geographic linkages make it possible for savers and issuers to gain incremental benefits in foreign and offshore markets, thereby enhancing liquidity and yield or reducing transaction costs.

\section{Shifts in Intermediary Market Shares}

Developments over the past several decades in intermediation processes and institutional design - both across time and geography - are striking. In the United States "commercial banks" (institutions that accept deposits from the pubic and make commercial loans) have seen their market share of domestic financial flows between end-users of the financial system decline from about 75 per cent in the 1950s to under 25 per cent today. In Europe the change has been much less dramatic, and the share of financial flows running though the balance sheets of banks continues to be well over 60 per cent- but declining nonetheless. And in Japan as well as much of the rest of Asia, 
banks continue to control in excess of 70 per cent of financial intermediation flows. Most emerging market countries cluster at the highly intermediated end of the spectrum, but in many of these economies there is also factual evidence of declining market shares of traditional banking intermediaries.

Classic banking functionality, in short, has been in long-term decline more or less worldwide. Where has all the money gone? Disintermediation as well as financial innovation and expanding global linkages have redirected financial flows through the securities markets. Exhibit 2 shows one of the symptoms of this migration at the global level, with capital market growth substantially more rapid than world economic growth during the period 1990-2004. The assets generated as a result of this disproportionate growth must have been the basis for an equally disproportionate growth in the asset management industry during this period.

Exhibit 3 decomposes this growth into the principal asset classes for the period from 1980 to 2003 and estimated to 2010 - i.e., the global stock of financial assets, comprising bank deposits, government debt securities, non-government debt securities and equities. The shares of the four components of global financial assets in selected regions is depicted in Exhibit 4.This shows the US share of global bank deposits and government debt securities declining substantially between 1980 and 2003, while the US share of non-government debt securities and equities increased. The European share of global bank deposits, equities and private debt securities increased, while all asset classes declined in Japan except for government debt securities. China accounts for a significant increase in global bank deposits, which is also the case of the rest of the world - primarily emerging market countries.

The fact that emerging markets are not immune from financial disintermediation can be shown in the example of Mexico. Exhibit 5 depicts the change in the allocation of household financial assets in Mexico from the end of 1996 to mid-2005, and demonstrates a reduction in saving deposits from $61 \%$ to $23 \%$ and an increase in securities holdings from $7 \%$ to $25 \%$, in mutual funds from $7 \%$ to $10 \%$ and in pension investments from $7 \%$ to $22 \%$ during this period. While total household financial assets grew from 2.3 to 4.3 trillion pesos, managed pension and non-pension assets grew from $9 \%$ to $27 \%$ of the total. This change in the structure of Mexico's financial assets suggests the importance of pension funds in financial disintermediation alongside a strong maturation of the country's financial system, with improved portfolio allocation alternatives for investors and financing alternatives for private sector borrowers.

These shifting patterns of growth in the various asset classes reflect very different states of play in the process of financial intermediation in various parts of the world. This is made clear in Exhibit 6 . Regions with the more highly developed financial markets - the US, the UK and the Euro-zone - have the smallest share of bank deposits and the largest share of equities and private debt securities as asset classe, the reverse of key developing countries. Korea is an exception, with a large privatesector debt market that stands in contrast to the government-dominated debt markets in 
most emerging market countries. Exhibit 7 suggests that Asian countries rely predominantly on bank financing, which severely limits the volume of securities (especially non-government debt obligations) available for investment by asset managers.

These data suggest that ultimate savers identified in Exhibit 1 residing in advanced financial systems increasingly use the fixed-income and equity markets directly and through fiduciaries which, through vastly improved technology, are able to provide substantially the same functionality as classic banking relationships immediate access to liquidity, transparency, safety, and so on - coupled to a higher rate of return. The one thing they cannot guarantee is settlement at par, which in the case of transactions balances (for example money market mutual funds) is mitigated by portfolio constraints mandating high-quality, short maturity financial instruments. Ultimate users of capital, located on the left side of Exhibit 1, have benefited from enhanced access to financial markets across a broad spectrum of maturity and credit quality using conventional and structured financial instruments. Although availability and financing cost normally depend on the current state of the market, credit and liquidity backstops can be easily provided.

At the same time, a broad spectrum of derivatives overlays the markets, making it possible to tailor financial products to the needs of end-users with increasing granularity, further expanding the availability and reducing the cost of financing on the one hand and promoting portfolio optimization on the other. And as the end-users have themselves been forced to become more performance-oriented in the presence of much greater transparency and competitive pressures, it has become increasingly difficult to justify departures from highly disciplined financial behavior on the part of corporations, public authorities and institutional investors.

In the process, two additional important and related differences are encountered in this generic financial-flow transformation. Intermediation shifts in the first place, from book-value to market-value accounting and in the second place from more intensively regulated to less intensively regulated channels, generally requiring less oversight and less capital for financial institutions and a greater emphasis on financial market practices. Both have clear implications for the efficiency properties of financial systems and for their transparency, safety and soundness.

\section{Contours of the Asset Management Industry: Mutual Funds and Hedge Funds}

The institutional asset-management industry is likely to be one of the largest and most dynamic parts of the global financial services sector in the years ahead. As of 2005 , the global total of assets under management was estimated at close to $\$ 100$ trillion, and expected to grow substantially going forward - see Exhibit 8. 
The underlying drivers of the market for institutional asset management are well understood. They include the following:

- A continued broad-based trend toward professional management of discretionary household assets in the form of mutual funds or unit trusts and other types of collective investment vehicles.

- The growing recognition that most government-sponsored pension systems, many of which were created wholly or partially on a pay-as-you-go (PAYG) basis, have become fundamentally untenable under demographic projections that appear virtually certain to materialize, and must be progressively replaced by asset pools that will throw-off the kinds of returns necessary to meet the needs of growing numbers of longer-living retirees.

- Partial displacement of traditional defined-benefit public- and private-sector pension programs backed by assets contributed by employers and working individuals under the pressure of the evolving demographics, rising administrative costs, and shifts in risk-allocation by a variety of definedcontribution schemes.

- Substantial increases in individual wealth in a number of developed countries and a range of developing countries, as shown by the changing shares in the growth of assets under management in Exhibit 8.

- Reallocation of portfolios that have - for regulatory, tax or institutional reasons been overweight domestic financial instruments (notably fixed-income securities) toward a greater role for equities and non-domestic asset classes, which not only promise higher returns but also may reduce the beneficiaries' exposure to risk due to portfolio diversification across both asset classes and economic and financial environments that are less than perfectly correlated in terms of total investment returns.

The growth implied by the first four of these factors, combined with the assetallocation shifts implied by the last of the above factors, will tend to drive the dynamics and the competitive structure of the global institutional asset management industry in the years ahead. The asset management services that are the focus of this paper are depicted in Exhibit 9.

First, retail clients have the option of placing funds directly with financial institutions such as banks or by purchasing securities from retail sales forces of brokerdealers, possibly with the help of fee-based financial advisers. Alternatively, retail investors can have their funds professionally managed by buying shares in mutual funds or unit trusts (again possibly with the help of advisers), which in turn buy securities from the institutional sales desks of broker-dealers (and from time to time 
maintain balances with banks).

Second, private clients are broken-out as a separate segment of the asset management market in Exhibit 9, and are usually serviced by private bankers who bundle asset management with various other services such as tax planning, estates and trusts, placing assets directly into financial instruments, commingled managed assetpools, or sometimes publicly-available mutual funds and unit trusts.

Third, foundations, endowments, and financial reserves held by nonfinancial companies, institutions and governments can rely on in-house investment expertise to purchase securities directly from the institutional sales desks of banks or securities broker-dealers, use financial advisers to help them build efficient portfolios, or place funds with open-end or closed-end mutual funds.

Fourth, pension funds take two principal forms, those guaranteeing a level of benefits and those aimed at building beneficiary assets from which a pension will be drawn (see below). Defined-benefit pension funds can buy securities directly in the market, or place funds with banks, trust companies or other types of asset managers, often aided by fund consultants who advise pension trustees on performance and assetallocation styles. Defined-contribution pension programs may operate in a similar way if they are managed in-house, creating proprietary asset pools, and in addition (or alternatively) provide participants with the option to purchase shares in publiclyavailable mutual funds.

The structure of the asset management industry encompasses significant overlaps between the four types of asst pools to the point where they are sometimes difficult to distinguish. We have noted the linkage between defined-contribution pension funds and the mutual fund industry, and the association of the disproportionate growth in the former with the expansion of mutual fund assets under management. There is a similar but perhaps more limited linkage between private client assets and mutual funds, on the one hand, and pension funds, on the other. This is particularly the case for the lower-bound of private client business, which is often commingled with mass-marketed mutual funds, and pension benefits awarded to high-income executives, which in effect become part of the recipient's high net-worth portfolio.

Asset management attracts competitors from an extraordinarily broad range of strategic groups. Commercial and universal banks, investment banks, trust companies, insurance companies, private banks, captive and independent pension fund managers, mutual fund companies, financial conglomerates and various types of specialist firms are all active in investment management. This rich array of contenders, coming at the market from several very different starting-points, competitive resources and strategic objectives, is likely to render the market for institutional asset management a highly competitive one even under conditions of large size and rapid growth. Securities firms (broker-dealers) have also penetrated the mutual fund market, and so have insurance companies reacting to stiffer competition for their traditional annuities business. 
Commercial banks, watching some of their deposit clients drift off into mutual funds, have responded by launching mutual fund families of their own, or marketing those of other fund managers. Such cross-penetration among strategic groups of financial intermediaries, each approaching the business from a different direction, makes mutual fund markets highly competitive.

Competitors in asset management in many markets include domestic and foreign-based commercial banks and savings institutions, securities firms (full-service investment banks and various kinds of specialists), insurance companies, finance companies (including financial subsidiaries of non-financial companies, such as General Electric), investment and financial advisers, private banks, and independent mutual fund management companies. Members of each strategic group compete with each other, as well as with members of other strategic groups. Success or failure depends heavily on portfolio management skills and service quality as well as economies of scale, capital investment and key technologies.

Exhibit 10 shows the ownership structure of the asset management industry in Europe and the United States, and illustrates the substantial diversity of firms active in the industry. Several ownership structures are solely on the "buy-side," notably standalone and independent asset managers - some of which are either cooperatives or closely-held - and those controlled by insurance companies. The remainder are controlled either by banks or by financial conglomerates active in both banking and insurance. Such asset managers arguably suffer from potential conflicts of interest since their parent organization may well be active on the capital-raising or "sell-side" as well, and in any case may be subject to intense performance pressure which could turn out to be detrimental to the investor clients.

In the following sections we will discuss briefly some of the key generic drivers influencing growth and competition in the three principal asset management domains mutual funds, pension funds and fiduciary asset pools managed for high net worth clients.

\section{Mutual Funds}

The mutual fund industry has enjoyed rapid growth in developed countries in recent decades, although there are wide differences among national financial markets in the pace of development, in the character of the assets under management, and in the nature of mutual fund marketing and distribution. Mutual funds essentially take the form of collective investment vehicles in which the proceeds from share sales to investors are placed in securities of various types. They are usually "mutual" in the sense that the investors own all of the assets in the fund, and are responsible for all of its operating costs. The funds are usually organized by a particular fund-management company that undertakes the legal registration of the fund, nominates a board of directors for the fund, and arranges for the distribution and sale of fund shares to the public. The fund's board 
of directors contracts with an investment advisor (usually the same fund management company) to manage the assets and to handle ongoing operational details such as marketing, administration, reporting and compliance.

Legally, mutual funds in the US, for example, take the form of "trusts" comprising the undivided sum of assets held on behalf of the investors by the trustees (directors) of the fund. US mutual fund assets never belong to either the fund (trust) itself or to the management company. Rather, they are owned by the fund investors themselves, who can normally redeem their shares instantly at their net asset value (NAV). US mutual funds were created as successors to the investment trusts of the 1920s, which suffered large losses during the stock market crash of 1929. The principal legislation governing the modern mutual fund industry is the Investment Company Act of 1940, which covers both the qualifications and registration of management companies of mutual funds sold to the public, as well as the disclosure of pertinent information to investors in the form of selling prospectuses and periodic reporting. A mutual fund's investment advisor must comply with terms of the Investment Advisers Act of 1940 and various state laws.

Mutual funds in Europe, on the other hand, usually take the form of either "coproperty" (co-ownership) and "company" structures. A typical example is France, where there are two types of mutual funds: Sociétés d'Investissement à Capital Variable (SICAVs) and Fonds Communs de Placement (FCPs). SICAVs invest accumulated capital subscribed by investors in shares, bonds, short-term paper, or other financial instruments. They are independent legal entities, governed by boards, and the investors are effectively shareholders who vote at annual shareholder meetings. FCPs consist of a "common property" of assets. They are not separate, independent legal entities, but rather "co-ownership entities," i.e., unit trusts which invest in different financial instruments - each investor is merely a co-owner of an undivided mass of assets of which he or she owns a percentage.

The SICAV model has been adopted under the EU's Undertakings for Collective Investments in Transferable Securities (UCITS) legislation, which governs how a fund can be marketed within the European Union and is designed to allow cross border fund sales to investors of different nationalities. Once registered under UCITS, fund shares may be sold in any EU country under a "single passport," subject only to the marketing rules of that country. Permissible UCITS investment vehicles include conventional equity and fixed-income securities, as well as high-performance "synthetic" funds based on futures and options not previously permitted in some financial centers such as London. Under UCITS, $90 \%$ of mutual fund assets must be invested in publicly traded companies, no more than $5 \%$ of the outstanding stock of any company may be owned by a fund, and there are limits on investment funds' borrowing rights. Real estate funds, commodity funds and money market funds are specifically excluded from UCITS.

In the United States at the end of 2005 there were more than 8,500 mutual funds available to the public, with total assets of about $\$ 8$ trillion, amounting to about half the value of all mutual funds globally. The number of US equity mutual funds were almost 
three times the 2,800 shares listed on the New York Stock Exchange. Equity mutual funds held $24 \%$ of US stock market capitalization and $10 \%$ of bond market capitalization. Mutual funds accounted for about $21 \%$ of US household net financial wealth in the early 2000s - more than life insurance companies and about equal to the total household deposits in commercial banks. As depicted in Exhibit 11, mutual funds were also prominent in various European countries but less so in some of the Asian countries, given the aforementioned greater reliance on the banking system for financial intermediation. The relative importance of mutual funds in gathering household assets in a number of developed countries is shown in Exhibit 11.

Competition for asset-gathering by mutual funds can be among the most Intense within financial systems, marked by advertising and extensive media coverage - they are in effect mass-market investment vehicles involving "branding" and public performance ratings by independent rating agencies. Mutual fund management companies have aggressively added banking-type services such as checking and cashmanagement accounts, credit cards and overdraft lines. Despite scale economies associated with the extraordinary growth in the size mutual funds, costs investors have increased over the years. The cost to investors of the average US equity mutual fund, for example, rose from 1.10 percent to 1.57 percent of net assets over the twenty years ending in $2000 .^{2}$ Indeed distribution efforts have targeted individual investors to attract them away from traditional banking and savings institutions - investors who are not particularly sophisticated about the fees, costs, performance metrics and expense reimbursement on the part of the fund management companies.

In Europe, mutual fund distribution through bank branches dominates in countries such as Germany (80\%), France (70\%) and Spain (61\%), with U.K. distribution concentrated among independent advisers and Italian distribution roughly split between bank branches and independent sales forces. The dominance of universal banks, savings banks and cooperative banks as financial intermediaries in most of the continental European countries explains the high concentration of mutual fund distribution via branch networks. ${ }^{3}$ In contrast, $90 \%$ of U.S. mutual fund distribution has been concentrated in financial intermediaries - notably on full-service broker-dealers who maintain large retail sales forces capable of penetrating the household sector and which are compensated mainly on the basis of commissions earned and assets under management - as well as discount brokers who have compensated for reduced sales effort and limited investment advice by charging lower fees and expenses. Insurance

\footnotetext{
${ }^{2}$ John Bogle, John Bogle on Investing, New York, McGraw Hill, 2000, p.163.

${ }^{3}$ For example, German mutual fund distribution is dominated by the major banks, with DWS (Deutsche Bank) controlling a 24\% market share, DIT (Dresdner Bank) 14.1\%, and ADIG (Commerzbank and the merged HypoVereinsbank) 21.1\%. However, foreign players such as Fidelity of the U.S. and Bank Julius Baer of Switzerland appear to be making significant inroads even as local competitors strive to improve investment performance, increase the range of products available, and enhance their non-European (particularly U.S.) funds marketed to German investors.
} 
agents account for $15 \%$ of U.S. mutual fund distribution, focusing on mutual funds with an insurance wrapper such as fixed and variable annuities and guaranteed investment contracts (GICs). Bank branches have played growing role in the U.S. after deregulation in 1999 although they only account for about 15\% distribution share, while direct sales by independent find managers have captured about $10 \%$ of sales.

Mutual fund managers offer a broad array of money market, fixed-income and equity funds, and invest heavily in technology platforms that enable efficient administration, custody and reporting functions in a customer-friendly manner. Some fund management companies manage dozens of mutual funds as well as other investment vehicles aimed at wealthier clients, such as hedge funds and private equity investments. Many if these funds are heavily traded: The median holding period of investors in US mutual funds in the 1950s was 6 years while in the 1990s it was 11 months. The overall equity fund portfolio turnover in the 1950 s was $17 \%$ per year; in 2000 it was 108\%. Such high portfolio turnover generates problems for long-term investors, including higher trading costs, tax inefficiency and lack of interest in governance issues among companies whose shares they hold.

The basis of competition in mutual fund management comprises five elements perceived performance, fees for performance, expenses, direct and indirect costs of marketing and distribution, and service quality and technology. The basic competitive variables are as follows:

- Investors must select from an array of investment types or styles based on asset classes (stocks, bonds, etc.). Fund managers are expected to remain true to their proclaimed investment objectives and attempt to optimize asset allocation in accordance with modern portfolio management concepts.

- Mutual fund managers incur a variety of operating costs and expenses in running their businesses, notably for personnel and facilities, commissions, and technology. The fund management company retained by the fund board enters into a contract for services in which it charges a fee for managing the assets, and its expenses, in part, are reimbursed. Combined, these fees are charged against the assets of the fund and comprise the fund's "expense ratio." Fund investors may also be subject to a sales charge when they invest (a "front-end load"), or at a later point when they exit (a "back-end load"), as well as a charge for marketing the fund to its investors. Funds generally subject investors to higher expense ratios when the fund size is smaller, the turnover is higher, or when the relative fund performance is better.

- Service quality in fund management involves ease of investment and redemptions, the quality and transparency of statements, cash management, tax computation and investment advice. 
- Mutual fund management companies tend to invest heavily in IT platforms in order to improve service quality and cut costs, investments that must be paid-for in the form of fees and expenses reimbursed by the funds.

One of the key issues relating to the mutual fund industry is assessing performance. Do fund managers, after expenses and fees, outperform available index funds or exchange-traded funds that reflect gains and losses of the market as a whole? Issues that need to be taken into account to address this question include the following:

- Time buckets (length, start/end periods) used for performance tracking.

- Index benchmark (e.g., S\&P 500 vs. Russell 2000) against which performance is measured.

- Survivorship bias (upward bias in the performance of surviving managed funds as poor performers fail and no longer appear in the data).

- Sharpe ratio (performance adjusted for risk).

- Management fees.

- Front loads, back loads, digressive loads in annual return-equivalents.

- Fees and other charges - such as US $12 b(1)$ fees - which regulators permit to be loaded onto fund investors.

- Performance distribution over market cycles.

- Performance distribution relative to sector means.

- The importance of fund names as reflecting investment styles, and the problem of style-drift.

- Persistence - do firms outperforming in one period continue to outperform in successive periods?

Confidence in mutual funds as transparent, efficient and fair investment vehicles was undermined with the uncovering of major scandals in 2003 and 2004, involving "late trading" and "market timing" in the shares of mutual funds with the knowledge and sometimes participation of the fund managers. The disclosures, legal proceedings and settlements led to extensive further investigations of mutual fund practices and governance procedures. 
Late trading allows a favored investor to illegally execute trades at the fund's 4 pm US daily closing net asset value (NAV) sometimes as late as $9 \mathrm{pm}$ the same evening, enabling the investor to "bet on yesterday's horse race" by profiting from news released domestically after the closing or released overseas in different time zones. Ordinary fund investors are obliged to trade at the $4 \mathrm{pm}$ price until it is reset at $4 \mathrm{pm}$ the following day. The practice, in effect, transfers wealth from ordinary shareholders to sophisticated hedge fund investors who had agreed invest "sticky assets" in lucrative (i.e., incorporating high performance fees for the fund manager) hedge funds to be sold to sophisticated buyers. For a fund management group to allow late trading is a major regulatory violation and a serious breach of fiduciary duty owed to the group's investors. One study has suggested that late trading cost investors about $\$ 400$ million per year between 2001 and 2004, or .005\% in annual returns for international mutual funds and $0.006 \%$ for domestic funds. ${ }^{4}$

Market timing trades in mutual fund shares - a practice not in itself illegal involves rapid-fire trading by favored investors in shares primarily of international mutual funds across time-zones. This practice skims the returns from the mutual fund shareholders, increases mutual fund expenses and requires them to hold large cash balances to meet abrupt withdrawals, costs which have to be borne by all investors, not just the market-timers. Investors permitted to engage in market-timing trades by fund managers again promised to park "sticky" assets with the fund management companies in their own hedge funds, in effect kicking-back some of their questionable markettiming gains to the fund management companies, not to the shareholders of the mutual fund. Market timing trades were estimated to have cost long-term US mutual fund investors about $\$ 4$ billion of dilution per year in the early 2000 s. $^{5}$

By July 2005 prosecutors in the US had extracted over $\$ 2.8$ billion in fines and penalties from some 24 mutual fund management companies in settlements in which those charged admitted no guilt. The funds managed by the investment groups that were named in the scandals suffered considerably more redemptions than firms that were not charged, including the industry's largest fund managers. Some observers argued that profit-making mutual fund managers' earnings are a function of the volume of assets under management, and so there is relentless pressure to grow those assets by offering an increasing variety of fund products to investors who benefit from their performance, liquidity and originality. Such pressure can cause fiduciary violations in all but mutually-owned fund managers and index funds, and perhaps should be seen as an unwelcome but tolerable friction to be endured in an industry that has benefited millions of people otherwise unable to invest safely in financial markets. In any event, the late trading and market timing scandals were not seen to cause enough damage to seriously

\footnotetext{
${ }^{4}$ Eric Zitzewitx, "How Widespread is Late Trading in Mutual Funds?," Stanford Business School Research Paper, Sept. 2003.

${ }^{5}$ Eric Zitzewitz, "Who Cares About Shareholders? Arbitrage Proofing Mutual Funds," Stanford Business School Research Paper, March 2002.
} 
impair mutual funds as investment vehicles, but they did raise serious questions among regulators, policy advocates and prosecutors regarding conflicting interests between mutual fund investors and the fund management companies that invest the assets. ${ }^{6}$

- Fund managers want independent directors who comply with the rules but are cooperative, supportive and not difficult to work with. Investors want directors who will robustly execute their fiduciary duties to the mutual fund shareholders.

- Fund managers want maximum fees and expense reimbursements. Investors want their fund directors to negotiate minimum total costs and for those costs to be fully disclosed.

- Fund managers want to ensure that they are reappointed. Investors want boards that act vigorously in their interests in selecting managers capable of top-flight risk-adjusted performance.

- Fund managers want to increase assets under management. Investors want optimum investment returns, after expenses and taxes.

- Fund managers want to promote their funds through brokers and financial advisers who need to be compensated. Investors do not want to pay these fees if they receive no benefits from them.

- Fund managers want to lower unreimbursed costs through soft dollar commissions from broker-dealers. Investors want best-price execution of trades and lowest commissions.

- Fund managers want to favor their own funds by obtaining "shelf space" in distribution channels, while investors want access through brokers to the best and most appropriate funds for them.

- Fund managers want to be able organize funds to assist other business interests of the firm, such as investment banking, and promoting investments in particular stocks. Investors want all investment decisions by the managers to be arm'slength and objective. ${ }^{7}$

These are generic conflicts of interest with which the mutual fund industry will have to come to terms if it expects to be an enduring part of the financial architecture. Containing exploitation of these conflicts will invariably depend on a combination of market discipline and effective regulation. Failure in either domain will drive assets onto the balance sheets of banks and into alternative investment vehicles.

\footnotetext{
${ }^{6}$ For a detailed discussion of the issues, see Roy C. Smith and Ingo Walter, Governing the Modern Corporation (New York: Oxford University Press, 2006).

7 Tom Lauticella, "US's SEC Asks Courts to Tighten Disclosure Edicts," Wall Street Journal, July 1, 2004.
} 
Mutual fund regulation in advanced financial markets require strict fit-and-proper criteria for management companies, as well as extensive disclosure of pertinent information. In the US the National Securities Markets Improvement Act of 1996 makes the Securities and Exchange Commission responsible for overseeing investment advisers with over $\$ 25$ million under management, with state regulators alone responsible for investment advisers with smaller amounts under management advisers who had previously been co-regulated together with the SEC. The large investment advisers falling under SEC jurisdiction account for about $95 \%$ of U.S. assets under management, although the vast majority of abusive practices and enforcement problems occur among the smaller firms. ${ }^{8}$

A great deal of mutual fund information is in the public domain, which helps market discipline along with the aforementioned high degree of transparency with respect to fund performance and ample media coverage and vigorous competition among funds and fund managers. This means that investors today face a generally fair and efficient market in which to make their asset choices. Overall, the mutual fund business, at least in the more developed markets, is probably a good example of how regulation and competition can come together to serve the retail investor about as well as is possible.

In contrast to the US, EU rules governing the operation and distribution of mutual funds have traditionally been highly fragmented. As of the 1990s, definitions of mutual funds varied from country to country, as did legal status and regulatory provisions. Door-to-door selling was forbidden in Belgium and Luxemburg, for example, and strictly regulated in Germany. In Britain, on the other hand, direct marketing was the norm. Market access to clients varied between the extremes of high levels of impenetrability to virtually complete openness. Stimulated by the UCITS initiative, discussed earlier, there is evidence that mutual fund regulation is gradually converging in the EU.

Not unexpectedly, the mutual fund management industry worldwide has seen a host of strategic initiatives among fund managers. These include mergers, acquisitions and alliances among fund managers as well as between fund managers and commercial and universal banks, securities broker-dealers, and insurance companies. In general the effect of competition in the industry has been to make it more customerfriendly, technology-sensitive, adaptive - and more concentrated. However, at least in the United States there has been little evidence of increasing market-concentration in the mutual fund industry over the years.

\footnotetext{
${ }^{8}$ Sana Siwolop, ARegulating Financial Advisers: Are the States Up To It?@ The New York Times, June 29, 1997.
} 
In 2005 the US mutual funds industry had a five-firm ratio of $39 \%$, a ten-firm ratio of $51 \%$ and a 25 firm ratio of $74 \%$ - these ratios were roughly constant for the previous 15 years. ${ }^{9}$ Factors that seem to argue for greater industry concentration in the future are economies of scale and band-name recognition. Arguments against further concentration include shifts in performance track-records and the role of mutual fund supermarkets in distribution, which increase the relative marketing advantage of smaller funds. One factor that may promote continued fragmentation of the mutual fund industry is that size itself can lead to significant performance problems.

\section{Hedge Funds and Private Equity Funds}

Hedge funds gained substantial prominence as investment vehicles in the late 1990s and early 2000s. At the end of 2004 there were estimated to be about 8,300 active hedge funds in existence worldwide, with assets under management approaching \$1 trillion and growing at about 20\% per year - see Exhibit 12 .

Hedge funds are lightly regulated investment vehicles - essentially closed-end investment pools with participations sold to wealthy individuals and institutional investors such as foundations, endowments and pension funds. Hedge funds originally sought to "hedge" the underlying risk of the market using various strategies designed to identify underpriced assets and overpriced assets, taking both long and short positions in order to remain essentially neutral with respect to overall market risk. Various types of derivatives and leverage were used to neutralize market risk and increase the size of positions in order to benefit from often very small pricing imperfections. Consequently, performance of many hedge fund strategies, particularly relative value strategies, was not dependent on the direction of the bond or equity markets -- unlike conventional equities or mutual funds, which are generally "long only" and fully exposed to market risk.

As the industry developed the classic hedging strategies evolved into a broad array of investment styles, so that hedge funds today are probably best described as "specialpurpose investment vehicles" which may or may not hedge their various exposures. Some strategies which try to be uncorrelated to equity markets are intended to deliver consistent returns with extremely low risk of loss, while others may be as or more volatile than mutual funds. Many, but not all, hedge fund strategies tend to hedge against downturns in the markets being traded. Most are flexible in their investment options and may use short selling, leverage, derivatives such as puts, calls, options and futures. The following are the principal investment styles that appear in the global hedge fund market today: ${ }^{10}$

- Aggressive Growth: Invests in equities expected to experience acceleration in growth of earnings per share.

\footnotetext{
${ }^{9}$ Investment Company Institute, Investment Industry Factbook, 2005 (Washington, D.C.: ICl, 2005).

${ }^{10}$ Source: Hedge Fund Association at http://www.thehfa.org/Aboutus.cfm
} 
- Distressed Securities: Buys equity, debt, or trade claims at deep discounts of companies in or facing bankruptcy or reorganization.

- Emerging Markets: Invests in equity or debt of emerging (less mature) markets which tend to have higher inflation and volatile growth.

- Fund of Funds: Mixes and matches hedge funds and other pooled investment vehicles. This blending of different strategies and asset classes aims to provide a more stable long-term investment return than any of the individual funds.

- Income: Invests with primary focus on yield or current income rather than solely on capital gains. May utilize leverage to buy bonds and sometimes fixed income derivatives in order to profit from principal appreciation and interest income

- Macro: Aims to profit from changes in global economies, typically brought about by shifts in government policy which impact interest rates, in turn affecting currency, stock, and bond markets.

- Market Neutral - Arbitrage: Attempts to hedge out most market risk by taking offsetting positions, often in different securities of the same issuer.

- Market Neutral - Securities Hedging: Invests equally in long and short equity portfolios generally in the same sectors of the market.

- Market Timing: Allocates assets among different asset classes depending on the manager's view of the economic or market outlook.

- Opportunistic: Investment theme changes from strategy to strategy as opportunities arise to profit from events such as IPOs, sudden price changes often caused by an

- Multi Strategy: Investment approach is diversified by employing various strategies simultaneously to realize short- and long-term gains.

- Short Selling: Sells securities short in anticipation of being able to re-buy them at a future date at a lower price due to the manager's assessment of the overvaluation of the securities, or the market, or in anticipation of earnings disappointments often due to accounting irregularities, new competition, change of management, etc.

- Special Situations: Invests in event-driven situations such as mergers, hostile takeovers, reorganizations, or leveraged buy outs.

- Value: Invests in securities perceived to be selling at deep discounts to their intrinsic or potential worth.

Most hedge funds are highly specialized, relying on the specific expertise of the manager or management team. Consequently, hedge fund managers' remuneration is 
heavily weighted towards performance incentives ( $20 \%$ or more of investment gains), in an effort to attract the best fund management talent. However, hedge fund expense ratios are also high - up to $2 \%$ of assets under management - so that hedge fund managers can do very well regardless of performance. Lock-ups usually prevent investors from withdrawing their funds for various periods of time, in order to allow hedge fund managers to execute their strategies. At the same time, since size can be the enemy of hedge fund performance, many successful hedge fund managers limit the amount of capital they will accept.

Private equity funds probably originated in the late 18th Century, when entrepreneurs in Europe and the US found wealthy individuals to back their projects on an ad hoc basis. This informal method of financing became an industry in the late 1970s and early 1980s when a number of private equity firms were founded. Private equity is now a recognized asset class. ${ }^{11}$

In contrast to hedge funds, private equity is a broad term that refers to any type of equity investment in an asset in which the equity is not freely tradable on a public stock market. Categories of private equity investment include leveraged buyouts, venture capital, growth capital, angel investing, mezzanine capital and others. Private equities are equity securities of companies that have not "gone public" (companies that have not listed their stock on a public exchange), and are generally illiquid and considered a long-term investment. Private equity usually includes forms of venture capital and management buyout (MBO) financing - i.e., both early stage (venture) and later stage (buyout) investing. In some cases the term "private equity" is used to refer only to the buy-out and buy-in investment sector. In other cases - for example in Europe but not the US - the term "venture capital" is used to cover all stages, i.e. synonymous with "private equity." In the US "venture capital" refers only to investments in early-stage and expanding companies.

Private equity investing reached a peak during the technology bubble of the late 1990 s and subsequently focused more on investment opportunities where the business has proven potential for realistic growth in an expanding market, backed by a wellresearched and documented business plan and an experienced management team ideally including individuals who have started and run a successful business before.

Private equity firms are especially active in restructuring situations, where shifts in technologies, international comparative advantage, overcapacity, bankruptcies and government policy changes have made existing businesses economically non-viable. This includes privatizations and strategic divestitures by major corporations and conglomerates, with substantial activity in this respect in countries like Germany, Japan and China. In this activity, private equity firms - which consider their core competence to be in industrial and financial expertise and relatively long investment periods - have had to compete with hedge funds looking for pure financial plays.

\footnotetext{
${ }^{11}$ British Venture Capital Association at http://www.bvca.co.uk/publications/guide/intro.html.
} 
In the following section, we review the collective investment funds in China, Indonesia, Korea, Malaysia, Singapore, Philippines and Thailand. The rest of the Asian economies either have no investment fund industries, or are at the very initial stages of development. We describe the current status of the fund industry in Asia focusing on size and growth of the industry, asset allocation of funds, regulatory environment surrounding the fund industry and the state of internationalization of the fund management industry in these countries.

\section{History of Collective Investment Schemes in Asia}

The collective investment funds in the countries that are the subject of this study were established as early as 1950s, but most did not begin to grow until the mid-1990s.

In the Peoples Republic of China (PRC) the first mutual fund was introduced in 1991, when local governments established two closed-end funds with total assets of Rmb 90 million. The first mutual fund listed on the Shanghai Stock Exchange began trading in 1993. In 2001 Hua'an Fund Management Company became the first Chinese asset manager to establish an open-end fund, and the number of open-end funds reached 142 in May 2005. By 2005 the number of open-end funds exceeded the number of closed-end funds (54 as of May 2005) in terms of assets under management and captured more than 70 percent of the mutual funds sector by value.

In Korea, collective investment schemes consist of investment trust companies (ITCs), securities investment companies (SICs), and trust accounts of banks. ITCs and bank trust accounts handle contractual type products whereby investors purchase beneficiary certificates. SICs, on the other hand, handle corporate-type products whereby investors purchase stocks of closed-end funds. The Securities Investment Trust Business Act was proulgated in 1969, and the first contractual-type Korean equity investment trust was introduced in 1970. In the summer of 1996, as part of Korean financial market reforms, investment trust companies were liberalized and the restrictions on their establishment were lifted. The number of domestic fund management companies reached 31 before the onset of the Asian financial crisis in late 1997. Thereafter the fund management industry shrank in size, but began recovering after 2000 with the implementation of improved operations and systems including markto-market valuations, better internal control standards, external audit of trusts assets and other reforms. At the end of 2004, the number of funds reached 45, including 11 companies with foreign shareholdings of over 50 percent. Corporate-type investment funds (Securities Investment Companies) were introduced in 1998 and are usually referred to as "mutual funds." At first, only closed-end funds were allowed, sales of open-end type mutual funds were permitted as from January 2001.

The first unit trust in Malaysia was established in 1959 by the Malayan Unit Trust Ltd. The Malaysian Government actively encouraged and sponsored the establishment of new funds during the initial years, and between 1959 and1976 18 new funds were established. Unit trust management companies, in the form of subsidiaries of financial 
institutions, came into existence in 1980s, and investor interest in unit trusts increased substantially through active marketing and distribution via banks' branch networks. The period from 1991 to 1996 marked a rapid growth of the unit trust industry in terms of the number of new management companies established, as well as assets under management. Unit trusts thus emerged as a key household savings product in Malaysia. The main types of mutual funds in Malaysia are equity unit trusts, property trusts, Islamic unit trusts, diversified unit trusts and specialty unit trusts, depending on the types of assets held.

Singapore hosts the most developed collective investment industry in the region. With more than 70 percent of total AUM sourced from abroad, Singapore is an international asset management center. Over 46 percent of total funds under management were sourced from the Asia-Pacific countries as of 2004.

The first mutual fund in Thailand was introduced in 1977. Until 1992, the Thai mutual fund industry was controlled by a single company (Mutual Fund Company), which was an affiliate of the government-owned Industrial Finance Corporation of Thailand. In 1992, the mutual fund industry was liberalized, triggering a rapid increase in the number of mutual funds. Both closed-end and open-end funds are available in Thailand, although there are many more open-end than closed-end funds.

\section{Size of Collective Investment Schemes in Asia}

The mutual fund industry in Asia remains small when compared to highly developed financial markets such as the US and Europe. As of end-2004, the net assets of the fund industry in the eight countries under review amounted to US $\$ 1,184$ billion, compared to a total of US $\$ 8,792$ bn in the Americas and US $\$ 5,628$ bn in Europe $^{12}$. There are considerable differences in relative sizes of the industry across individual countries in Asia. The three largest fund management industries in the region are Japan (US\$548.8 bn), Singapore (US\$349.2 bn) and Korea (US\$180.7 bn). China, Malaysia, Thailand and Indonesia have very small managed fund markets, totaling to US\$39.2 bn, US $\$ 30.0$ bn, US\$ 24.0 bn and US\$ 11.1 bn respectively. In the rest of the countries in Asia - which we do not cover in this study - the mutual fund industry is either negligible or non-existent.

In China, there were 54 closed-end and 142 open-end mutual funds in operation at end-May 2005, managed by 40 fund-management companies, which accounted for over Rmb 379 billion in assets under management. Mutual funds remain a very small part of the Chinese financial system - funds under management at the end of 2005 amounted to only about $1 \%$ of the assets of the country's banking system.

${ }^{12}$ Source: Investment Company Institute and Korea Institute of Finance. 
In Indonesia, 47 investment managers operated 186 funds (Capital Market Supervisory Agency; Bapepam) and total assets managed by investment funds amounted to Rp 69.48 trillion at the end of 2003.

Total net asset value of investment trusts was RM 87.39 billion at the end of 2004 in Malaysia_-- RM 80.63 billion comprised conventional unit trust funds and the remaining RM 6.76 billion were Islamic-based funds (Exhibit 13). The funds are invested heavily in equities. As of end-2004, 65.8 percent of the funds were invested in equities, 11 percent in fixed income securities and 19.5 percent is held in cash (See Exhibit 14).

The Philippine mutual fund industry is the smallest and most underdeveloped in the region among the countries covered. As of August 2005, there were 34 investment companies in the Philippines - 33 open-end mutual funds and one closed-end fund total assets of the fund management industry stood at P 29.4 billion. Less than $2 \%$ of the funds invested in the Philippine Stock Exchange were channeled through mutual funds in 2005.

Pension funds and mutual funds overlap in the Singaporean financial system, and it is difficult to disentangle data for collective investment schemes (unit trusts). According to Monetary Authority of Singapore, total unit-trust assets amounted to $\mathrm{S} \$ 19.8 \mathrm{bn}$ as of end-2004, comprising 379 unit trusts in the country. Assets under management for the funds approved by the Central Provident Fund Investment Scheme amounted to $S \$ 14.2$ billion in 2004, constituting about 72 percent of the total AUM by the fund management industry.

In Thailand, there were 506 registered mutual funds, including 23 closed-end and 375 open-end funds as of end-November 2004 (Exhibit 15). These funds were managed by 16 licensed fund-management companies, which had a combined Tbt 664.9 billion in assets under management.

As these observations suggest, the mutual fund industry remains small in Asia. In addition to being limited in size, the industry occupies a minor niche in most domestic financial systems dominated by banks in the region. For example, total assets of mutual funds amount to only one percent of the assets of the banking system in China. Mutual funds made up just 12.9 percent of the total market capitalization of Bursa Malaysia at end-July 2005. The percentage of household assets invested in mutual funds amount to only 3 percent on Japan, 4 percent in Korea. For comparison, the ratio is 21 percent for U.S. household assets and 13 percent for European household assets.

\section{Asset Allocation in Asian Investment Funds}

The mutual fund industry in Asia generally suffers from a lack of available local debt and equity instruments in which to invest, restrictions on asset allocation and foreign portfolio investments and is some cases limited liquidity of the available assets. 
In China, the regulations dictate that no more than 10 percent of a mutual fund can be invested in any one company, and no more than 10 percent of a company's shares can be held by any one mutual fund. Moreover, 80 percent of assets held by mutual funds must be invested in the equity and bond markets, and at least 20 percent must be invested in Treasury bonds. As of 2004, 57.3 percent of mutual fund assets were invested in equity funds and 26 percent were invested in the money market instruments.

In Indonesia, funds are classified into fixed income funds, money market funds, discretionary funds and equity funds. However, Indonesian investment-fund assets are predominantly placed in fixed-income investments (public-sector bonds and moneymarket funds). The share of equity funds is only 1.8 percent of all fund assets. The 2005 mutual fund crisis in Indonesia presented a good case study of the dangers of insufficient diversification and heavy reliance on fixed income securities.

In Korea, investment trust companies are classified into stock-type (required to hold at least 60 percent of assets in stocks), bond-type (at least 60 percent must be invested in bonds) and mixed-type or "blended" investment funds. In addition, there are money market funds that invest mainly in commercial paper and short-term government bonds and monetary stabilization bonds. Exhibit 16 provides the breakdown of investments as provided by the Korea Investment Trust Companies Association. The funds are invested heavily in the money market and bond market. As of 2004, 40.8 percent of funds under management were held in bonds and 32.2 percent were held in the money market.

In Malaysia, fund management companies rely heavily on equities for their asset allocation strategies, with 65.8 percent of assets allocated to equity investments. Malaysia is the country with greatest share of funds invested in equities (Exhibit 14).

In Singapore, unit trusts are likewise heavily invested in the equity markets. The share of equities is 44.4 percent, the share of bonds is 22.1 percent and the share of money market instruments is 16.5 percent as of end-2004. From negligible levels in 2000, alternative investments, commodities, derivatives and foreign exchange products accounted for 11 percent of total AUM at end-2004 (Exhibit 17).

To summarize, although different classes of mutual funds are available in the Asian countries (equity-funds, bond-funds and mixed funds), significant proportion of mutual funds' assets are invested in short-term money market instruments and government bonds in most of the countries in the region with the exception of China, Malaysia and Singapore, where investments in equities dominate (Exhibit 18). Still, even countries where a significant share of funds are invested in equities suffer from limits on portfolio diversification - mainly due to lack of investable securities, the requirements set by regulators on the composition of funds, and restrictions on offshore investments. 


\section{Regulation of the Investment Fund Industry in Asia}

Regulatory authorities in Asia have made a serious effort to promulgate legislation and regulation to support a properly structured mutual fund industry - one that will strengthen efficiency in financial intermediation. All countries in this study except Indonesia, have reorganized their regulatory systems covering the fund management industry in the form of independent and centralized systems, incorporating different regulatory regimes and functions that had previously been spread over various agencies such as ministries of finance and central banks. Indonesia is in the process of centralizing and has established a committee for the integration of the regulatory units. This transition is in line with the regulatory trend in more mature financial markets -- for example, the UK's Financial Services and Markets Act of 2000 (FSMA) and Japan's Act of Investment Trust and Investment Corporation, which were promulgated based on the principle of regulation by function. The Asian countries have also completed enacting laws that significantly liberalized the fund management industry and revised establishment criteria.

The mutual-fund industry in China was largely unregulated until 1997, when the Investment Fund Law was passed. The Securities Investment Fund Law superseded that legislation in June 2004 and set requirements for the establishment and trading of the funds. The main requirements for establishing a fund are that it maintain a minimum registered capital of Rmb 100 million and that the major shareholder in the fund must be a company specialized in the securities business, with no record of regulatory infringements over the previous three years and with capital of at least Rmb 300 million. Funds must designate a custodian in the form of a commercial bank approved by the CSRC, whose tasks include safekeeping of fund assets, establishing accounts, maintaining records and handling settlement and delivery. In February 2005, the People's Bank of China, China Banking Regulatory Commission and China Securities Regulatory Commission (CSRC) jointly issued the Administrative Rules for Pilot Incorporation of Fund Management Companies by Commercial Banks. The rules seek to ensure segregation of commercial banks' banking business and their fundmanagement business. The China Banking Regulatory Commission oversees the asset management companies, the international trust and investment companies, and the banks' factoring activities. The China Securities Regulatory Commission supervises the mutual funds and also the emerging share investment activities of the national pension fund.

As noted, in Indonesia regulation of the mutual fund industry has not yet been centralized and there is no unitary regulatory framework. The Central Bank, Ministry of Finance and Capital Market Supervisory Agency (Bapepam) share responsibility for regulation.

In Korea, The Indirect Investment Asset Management Business Act was enacted in October 2003 and came into force in January 2004 for the regulation of the asset management industry. Previously, the contractual-type funds had been regulated by 
the Securities Investment Trust Business Act, corporate-type funds by the Securities Investment Company Act, unspecified money trusts by the Trust Business Act, and variable insurance products by the Insurance Business Act. The 2003 Act was based on the Securities Investment Trust Business Act and provides that the full range of asset management activities be regulated equally by unifying all asset management-related regulations. The new Act widened the scope of investible assets to include exchangetraded derivatives, OTC derivatives, real estate, real assets, and similar products. The Act also established regulations covering management of fund assets. Investment by any one indirect investment vehicle in investment securities of the same issuer can not exceed 10 percent of total assets, an asset management company can not invest in more than 20 percent of the outstanding shares of a company, comprising the cumulative exposure of all of its direct and its indirect investment vehicles. Also, asset management companies are required to publish investment prospectuses and quarterly performance reports, and must report to the FSC on a monthly basis. ${ }^{13}$

In Malaysia, the regulation of the investment fund industry was centralized with the establishment of the Securities Commission (SC) in March 1993, coupled with the implementation of the Securities Commission Regulations in1996. The Securities commission adopted a full disclosure-based regulatory framework in May 2003, and accelerated the assessment of applications for the issuance of unit trusts and prospectus registration, and reinforced disclosure and reporting requirements. The regulations also allow third-party distribution and the licensing of tied agents involved in the distribution of unit trusts, and allowed stock brokerage companies to manage unit trusts. These changes provided substantial impetus to growth and development in the industry. The Malaysian Capital Market Master Plan serves as a guideline for the financial sector through 2010, and encourages the continued liberalization of mutual funds that began in 1997. The Federation of Malaysian Unit Trust Managers seeks to develop the industry by improving the regulatory and legal environment for unit trusts with a view to formulating business policies beneficial to the industry, providing information and assistance to its members, and promoting awareness of the industry among the general public.

Mutual-fund activities in the Philippines are regulated by the SEC under the Investment Company Act. Investment companies are required to have a minimum subscribed and paid-up capital of P 50 million, and to submit their investment objectives and plans to the SEC for approval.

In Singapore, The Monetary Authority of Singapore (MAS) has been responsible for regulation of mutual funds since 1999. MAS introduced the Business Trusts Act to regulate the trust business, which was passed by Parliament in September 2004 and came into effect in January 2005.

\footnotetext{
${ }^{13}$ See http://www.amak.or.kr/Eng/Investment/InDisclosure.aspx for additional information. On fund taxation in Korea, see http://www.amak.or.kr/Eng/Investment/InTaxation.aspx.
} 
Securities and Exchange Commission regulates the unit trust industry in Thailand. Since August 2003 all financial institutions are allowed to apply for mutualfund management licenses, although only through separate entities in which they own at least 75 percent. In February 2005 the SEC and the Association of Investment Management Companies (AIMC) proposed additional risk disclosures for mutual funds operating in Thailand.

Principal regulatory restrictions in the fund management industry in the region can be summarized as entry criteria such as minimum capital requirements, minimum number of investors to establish the fund, number of years of experience as a fund manager and limits on asset allocation. However, the specifics of the regulations vary to a great extent among countries. For example, the minimum capital requirement for an asset management company is US\$12 $\mathrm{mn}$ in China, US\$1 mn in Korea.

\section{Internationalization of the Mutual Fund Industry in Asia}

The asset management industry in Asia is opening to global financial markets, but restrictions on foreign capital as well as overseas investment of funds remain. The domestic funds in the region face restrictions to invest in offshore markets, which severely restricts competition in the fund management industry as well as opportunities for portfolio diversification. Exhibit 19 summarizes the current state of restrictions on the international operations of funds.

In China, the first joint-venture fund was established in 1991 and more than 50 foreign-related mutual funds had been set up by 1995, traded both within and outside the PRC. Besides forming joint ventures, foreign fund management companies have begun to enter the Chinese market by buying shares in local fund managers. Foreign companies are allowed to take stakes of up to 49 percent in local fund managers, a ceiling that is scheduled to rise to 51 percent by 2007 . The foreign fund-management partner in any Sino-foreign joint venture must have a paid-up capital of at east Rmb 300 million. Investment in foreign assets remain restrictive in China. In 2003, the State Administration of Foreign Exchange (SAFE) established new rules for overseas investments by the local fund management companies, requiring them to seek permission before setting up special foreign exchange capital accounts through which overseas investment funds must be channeled.

In order to attract foreign capital, Korea abolished all restrictions on foreign investment in stocks and bonds in 1998. Foreign fund management companies can enter the local fund management industry by establishing a branch, subsidiary or joint venture, or by taking over existing holdings in an asset management firm. In order to set up a local branch, the foreign firm must have sufficient experience in the fund management industry and meet international criteria for asset allocation and operations. For a foreign asset management firm to be active in the Korean mutual fund industry, the four key criteria are that: 1) It must already have been in the asset management 
business abroad; 2) Its assets under management must exceed W 5 trillion; 3 ) Is credit rating must be investment-grade; and 4) It must not have been subject to criminal or administrative sanction in its home country.

In Malaysia, the Securities Commission planned to open the sector to foreign companies from July 2003, but postponed the liberalization to give domestic companies more time to strengthen their operations before facing foreign competitors. From April 2005 Bank Negara Malaysia allowed mutual funds to raise foreign investments up to 30 percent of funds under management. Mutual-fund managers investing abroad are required to seek the Securities Commission's prior approval regarding the foreign exchanges in which they intend to invest.

In Indonesia, Bapepam issued a ruling in August 2002 allowing mutual funds to buy offshore securities (public offerings abroad and securities listed on foreign exchanges), as long as information on the securities can be accessed via the mass media or the Internet and total purchases do not exceed 15 percent of net asset.

In the Philippines, the proposed legislation, the Revised Investment Company Act, aims to diversify the investor base by eliminating restrictions on foreign ownership of investment companies. The bill also proposes to allow foreign mutual funds to sell securities in the Philippines, provided that a portion of funds raised from any public offer is invested domestically. In February 2001 , in response to prolonged weakness in the local equities market, the SEC allowed Philippine-registered mutual funds to invest 20 percent of their portfolio in foreign securities. The investments require prior approval from the central bank if they exceed US \$6 million annually. Mutual funds issued outside the Philippines cannot be sold in the country unless they are registered with the SEC.

In Singapore, offshore mutual funds and unit trusts have been able to offer units to Singapore residents since July 2002.

In Thailand, the SEC in 2002 approved five mutual-fund management companies to establish and manage Foreign Investment Funds (FIFs) at a level of US \$200m per year. Investors are permitted to invest in overseas securities via FIFs..

To summarize, Korea and Singapore have completely liberalized the entry of foreign-based funds. China allows foreign-based investment management companies enter the domestic market in the form of joint ventures, with foreign ownership capped at 49 percent. Foreign-based fund managers are allowed to enter the market in Malaysia with the Securities Commission's approval. In the Philippines, the authorities are working on legislation that will allow foreign funds to be listed in the domestic markets.

Investment funds in the region face various restrictions on asset allocation in foreign securities, which severely restricts competition in the fund management industry as well as opportunities for portfolio diversification. Again, Korea and Singapore have 
removed all such restrictions. Other countries, however, impose caps on the percentage of assets that can be invested in overseas markets. In Indonesia, funds are allowed to invest less that 15 percent of their net assets abroad. In Malaysia, the limit is 30 percent. In the Philippines the limit is 20 percent and the funds must seek prior approval from the central bank in order to invest in offshore markets. Finally in Thailand the funds can invest up to a US\$200 million in a yearly basis.

\section{Summary}

There are considerable differences in the extent of development of the industry across individual countries in Asia. The mutual fund industries of selected Asian countries, reviewed here, show a number of commonalities as well as differences. Most started out as closed-end funds before allowing open-end funds, a more investorfriendly vehicle that has the advantage of avoiding the discounts often encountered in closed-end funds. In each case mutual funds occupy a very small niche in the domestic financial system, which is likely to grow in the future - as it has in developed financial markets. In each case as well, the mutual fund industry suffers from a lack of available local debt and equity instruments in which to invest, restrictions on asset allocation and on foreign portfolio investments, and in some cases questionable liquidity. Banks seem to be the principal vehicle for manufacturing and distributing mutual funds, which raises the issue of conflicts with comparable banking products. Finally, in most cases the authorities have made a serious effort to promulgate legislation and regulation support a properly structured mutual fund industry that will contribute to efficiency in local financial intermediation.

Despite its small size compared to the mature financial markets, the growth rate of the mutual fund industry in the Asian region is rapid. In 2004, the mutual fund industry recorded a growth rate of 29.6 percent. In China, the industry grew at 89.4 percent. The corresponding rates of growth in the Americas and in Europe were 10.3 percent and 20.2 percent respectively. The industry is likely to continue growing rapidly as private wealth accumulates in the region - and as pension funds are increasingly liberalized (see below) to allow higher portions of assets under management to be invested in collective investment schemes.

\section{Contours of the Asset Management Industry: Pension Funds}

The pension fund market for asset management has been one of the most rapidly-growing domains of the global financial system, and promises to be even more dynamic in the years ahead. Consequently, pension assets have been in the forefront of strategic targeting by all types of financial institutions, including banks, trust companies, broker-dealers, insurance companies, mutual fund companies, and independent asset management firms. Pension assets in 2005 in countries where consistent and comparable data are available were estimated to amount to $\$ 23$ trillion, roughly two- 
thirds of which covered private-sector employees and the balance covered public-sector employees. About $40 \%$ of global pension assets under management are in the United States, while Europe had pension assets of about $\$ 8.7$ trillion in 2005, which is expected to increase to almost $\$ 20$ trillion by $2015 .{ }^{14}$

The basis for such projected growth is of course the demographics of gradually aging populations, colliding with existing structures for retirement support which in many countries carry heavy political baggage. They are politically exceedingly difficult to bring up to the standards required for the future, yet doing so eventually is an inevitability. The near-term foci of this problem will be Europe and Japan, with profound implications for the size and structure of capital markets, the competitive positioning and performance of financial intermediaries in general and asset managers in particular.

The demographics of the pension fund problem are straightforward, since demographic data are among the most reliable. Unless there are major unforeseen changes in birth rates, death dates or migration rates, the dependency ratio (population over 65 divided by the population age 16-64) will have doubled between 2000 and 2040 , with the highest dependency ratios in the case of Europe being attained in Italy, Germany and the Netherlands, and the lowest in Ireland. Japan has dependency ratios ever higher than Europe, while the US ratio is somewhat lower - with the lowest generally found in developing countries. All, however, are heading in the same direction.

While the demographics underlying these projections may be quite reliable, dependency ratios remain subject to shifts in working-age start- and end-points. Obviously, the longer people remain out of the active labor force (e.g., for purposes of education), the higher the level of sustained unemployment, and the earlier the average retirement age, the higher will be the dependency ratio. The collision comes between the demographics and the existing structure of pension finance. There are basically three ways to provide support for the post-retirement segment of the population:

- Pay-as-you-go (PAYG) programs. Pension benefits under this approach are committed by the state based on various formulas - number of years worked and income subject to social charges, for example - and funded by current mandatory contributions of those employed (taxes and social charges) that may or may not be specifically earmarked to covering current pension payouts. Under PAYG systems, current pension contributions may exceed or fall short of current disbursements. In the former case a trust fund may be set up which, as in the case of U.S. Social Security, may be invested in government securities. In the latter case, the deficit will tend to be covered out of general tax revenues, government borrowing, or the liquidation of previously accumulated trust fund assets.

\footnotetext{
${ }^{14}$ Allianz Global Investors at http://www.allianz.com/azcom/dp/cda/0,,763416-44,00.html
} 
- Defined benefit programs. Pension benefits under such programs are committed to public or private-sector employees by their employers, based on actuarial benefit formulas that are part of the employment contract. Defined benefit pension payouts may be linked to the cost of living, adjusted for survivorship, etc., and the funds set-aside to support future claims may be contributed solely by the employer or with some level of employee contribution. The pool of assets may be invested in a portfolio of debt and equity securities (possibly including the company's own shares) that are managed in-house or by external fund managers. Depending on the level of contributions and benefit claims, as well as investment performance, defined-benefit plans may be over-funded or underfunded. They may thus be tapped by the employer from time to time for general corporate purposes, or they may have to be topped-up from the employer's own resources. Defined benefit plans may be insured (e.g., against corporate bankruptcy) either in the private market or by government agencies, and are usually subject to strict regulation - e.g., in the United States under ERISA, which is administered by the Department of Labor.

- Defined contribution programs. Pension fund contributions are made by the employer, the employee, or both into a fund that will ultimately form the basis for pension benefits under defined contribution pension plans. The employee's share in the fund tends to vest after a number of years of employment, and may be managed by the employer or placed with various asset managers under portfolio constraints intended serve the best interests of the beneficiaries. The employee's responsibility for asset allocation can vary from none at all to virtually full discretion. Employees may, for example be allowed to select from among a range of approved investment vehicles, notably mutual funds, based on individual risk-return preferences.

Most countries have several types of pension arrangement operating simultaneously - for example a base-level PAYG system supplemented by statesponsored or privately-sponsored defined-benefit plans and defined-contribution plans sponsored by employers, mandated by the state or undertaken voluntarily by individuals.

The collision of the aforementioned demographics and heavy reliance on the part of many countries on PAYG approaches is at the heart of the pension problem, and forms the basis for the future growth of asset management. The conventional wisdom is that the pension problems that are today centered in Europe and Japan will eventually spread to the rest of the world. They will have to be resolved, and there are only a limited number of options in dealing with the issue:

- Raise mandatory social charges on employees and employers to cover increasing pension obligations under PAYG systems. This is problematic specially in countries that already have high fiscal burdens and increasing pressure for avoidance and evasion. A similar problem confronts major increases 
in general taxation levels or government borrowing to top-up eroding trust funds or finance PAYG benefits on a continuing basis.

- Undertake major reductions in retirement benefits, cutting dramatically into benefit levels. The sensitivity of fiscal reforms to social welfare is illustrated by the fact that just limiting the growth in pension expenditures to the projected rate of economic growth from 2015 onward would reduce income-replacement rates from $45 \%$ to $30 \%$ over a period of 15 years, leaving those among the elderly without adequate personal resources in relative poverty.

- Apply significant increases in the retirement age at which individuals are eligible for full PAYG-financed pensions, perhaps to age 70 for those not incapacitated by ill health. This is not a palatable solution in many countries that have been subject to pressure for reduced retirement age, compounded by chronically high unemployment especially in Europe, which has been widely used as a justification for earlier retirements.

- Undertake significant pension reforms to progressively move away from PAYG systems toward defined-contribution and defined benefit schemes such as those widely used in the U.S., Chile, Singapore, Malaysia, the U.K., the Netherlands and Denmark. These differ in detail, but all involve the creation of large asset pools that are reasonably actuarially sound.

Given the relatively bleak outlook for the first several of these alternatives, it seems inevitable that increasing reliance will be placed on the last of these options. The fact is that future generations can no longer count on the present value of benefits exceeding the present value of contributions and social charges as the demographics inevitably turn against them in the presence of clear fiscal constraints facing governments. This bodes well for the future growth of the asset management industry emanating from the pension sector.

Whereas there are wide differences among countries in their reliance on PAYG pension systems and in the degree of demographic and financial pressure to build actuarially viable pension asset pools, there are equally wide differences in how those assets have been allocated. The United States (not including the Social Security Trust Fund) and the United Kingdom have relied quite heavily on domestic equities. The same is true in the UK, although pension pools in many of the other European countries and Japan have relied more heavily of fixed-income securities. Similar differences exist among emerging market countries.

The dramatic shift from defined benefit to defined contribution pension plans in the United States, as an example, has led to strong linkages between pension funds and mutual funds. Numerous mutual funds - notably in the equities sector - are strongly influenced by $401(\mathrm{k})$ and other pension inflows. At the end of 2005 , about $67 \%$ of mutual fund assets represented retirement accounts of various types in the United 
States. Some $50 \%$ of total retirement assets were invested in mutual funds, up from about $1 \%$ in $1980 .{ }^{15}$ This is reflected in the structure of the pension fund management industry in the United States.

In the most competitive parts of the pension sector, access to fund trustees often relies on consultants. Company-sponsored retirement plans often seek advice from pension investment consultants before awarding pension mandates, or to include particular mutual funds or fund families in the menu they offer to employees in $401 \mathrm{k}$ plans. Consultants are particularly useful in formal reviews of pension fund managers, the frequency of which (based in survey data) is depicted in Exhibit 20. Fund management companies may and sometimes do provide fee- or expensereimbursement to consultants, a practice that has increased in recent years. In the case of pension funds, the investment manager quotes a single, all-in expense to be charged for services which is sufficient to cover expenses and the manager's profit. Pension fund trustees are able to apply the fund's bargaining power to the process.

To summarize, with respect to the pension component of growth in the asset management industry there is no single "magic bullet" solution to supporting the retirement of the "bulge" of baby boomers moving through population structures. Countries that are taking action are using a multi-pronged approach consisting of:

- Increase working populations. Immigration and increased labor force participation rates help but cannot solve the problem. Some perverse incentive structures impede labor force participation rate improvements.

- Increase productivity. Strong productivity growth is the single most important factor in alleviating the burden of global aging. However, productivity growth is difficult if not impossible to predict, and aging countries cannot rely on it.

- Change the promise. Although it is politically difficult, countries are changing the minimum retirement age, modifying benefit levels and making it more tax advantageous for the elderly to work. As individuals realize that the benefit reductions already enacted and the future reductions will affect their retirement income, they may increase their savings.

- Change the funding. Those countries with healthy funded private pension funds are in a better position to support their elderly population than those that rely on unfunded PAYG systems. Some countries are establishing funded pension trusts or using the proceeds of privatizations to establish trust funds for future generations. Others are encouraging personal plans or increasing funding ceilings on existing personal pension plans.

\footnotetext{
${ }^{15}$ Brian Reid and Jean Crumrine, Retirement Plan Holdings of Mutual Funds, 1996 (Washington, D.C.: Investment Company Institute, 1997).
} 
The consensus seems to be that the latter option provides the best way forward, both for advanced countries as well as for emerging market countries. And when this is combined with the shift from defined benefit to defined contribution approaches, discussed earlier, it should provide ample competitive opportunities for the asset management industry globally and within the Asian region. In this section, we review the state of the pension fund industry in Asia. Many countries have built, or are in process of building defined benefit and defined contribution programs in order to mitigate the effects of aging populations on future pension system deficits. The growth of the defined benefit and defined contribution plans throughout Asia forms the basis for the future growth of asset management, as these programs involve the creation of large asset pools.

\section{The Pension Fund Management Industry in Asia}

The pension system in the Asian countries is predominantly organized and managed by their respective governments. In Malaysia and Singapore, for example, single government-managed pension funds dominate the domestic asset management industry and they are among the largest pension systems in the world. However, private funds in many of the countries are recently being introduced in order to supplement existing public pension schemes (Exhibit 21).

China in 1995 modified its public pension system was changed from a pure payas-you-go (PAYG) system to one comprising a PAYG portion and a funded portion. In 1997, more than 800 pension-fund schemes in operation throughout China were instructed to become unified by 2000 ("Decision on the Establishment of a Unified Basic Old Age System for Enterprise Staff and Workers") and the National Council for Social Security Fund (SSF) was established at the same time to manage and administer the fund's assets. Under China's unified pension system, employers pay 20 percent of employees' annual salary into a Social Security Fund and 3 percent into an individual pension account. The employees pay 8 percent of their salaries into the individual account.

China introduced voluntary corporate pension plans (Enterprise Annuity) as a supplement to social security in 1992. Companies that establish an Enterprise Annuity (EA) plan must also participate in the social security system, be up to date on contributions, appoint a trustee to oversee the plan, and manage annuity assets separately from the assets of the company and those of the asset management service providers.

The Indonesian public insurance system includes three mandatory programs covering private sector employees, civil servants, and the armed forces. Jamsostek (Jaminan Sosial Tenaga Kerja) is mandatory savings scheme that provides coverage for employees of private sector and state-owned enterprises (SOEs) with 10 or more employees or a monthly wage bill of at least Rp1 million. Taspen (Tabungan dan 
Asuransi Pegawai Negari) covers all civil servants and Asabri (Asuransi Social ABRI) covers the police, and civilian and military defense personnel. Asabri is funded from current contributions and the Government's general budget, and Taspen is partially funded from current and accumulated contributions, but is largely funded from the general budget. Jamsostek covers a provident fund and life insurance, work accident protection and health insurance. Under Jamsostek's provident fund plan, employers contribute 3.7 of employees' total salaries and employees contribute 2 percent of monthly wages. Taspen and Asabri are both run as state-owned limited-liability companies. Under Taspen, worker contributions are 4.75 percent of basic monthly salary and benefits are set at 2.5 percent of basic salary plus family allowance for each year worked (up to a maximum of 75 percent of basic salary and allowance) and are paid out when workers reach the age of 56 .

The mandatory public programs in Indonesia were established by separate laws and are supervised by separate ministries. The Jamsostek program is under the supervision of the Ministry of Manpower and Transmigration, the Taspen program is controlled by the Ministry of Finance, and the Asabri program is controlled by the Ministry of Defense. The Ministry of Finance's Pensions Directorate has authority to supervise voluntary pension schemes, but not the mandatory programs of Asabri or Jamsostek, which are considered effectively unsupervised.

The mandatory public pension schemes in Indonesia can be supplemented by employees in the private sector through voluntary pensions (dana pensiuns) of two types - employer pension funds (DPPKs) and financial institution pension funds (DPLKs). There were 327 pension funds in existence as of December 2003, including 299 employer pension funds and 28 financial institutions funds. Employer pension funds may be run either as defined-benefit plans or as defined contribution plans. The country's leading banks and insurance companies operate the largest independent pension funds. The Ministry of Finance Pensions Directorate has the authority to supervise voluntary pension schemes in Indonesia. The 1992 pension fund law requires that any company which has promised retirement benefits to its employees must set up a pension fund registered with the Directorate of Pensions or join a program established by a financial institution. Assets of pension funds must be segregated from those of the parent company. The law is ambiguous, however, about who can manage pension funds. In effect, they may be managed directly by their founders or by registered investment managers. Contributions are tax-deductible within prescribed limits, and investment earnings on the funds are tax-free.

The Korean public pension scheme consists of the National Pension Scheme for employees of private companies and the self-employed persons, Government Employees Pension Scheme, Military Personnel Pension Scheme, and Private School Teachers Pension Scheme. Under the National Pension Act introduced in 1988, workers pay up to 9 percent of their monthly income to the national pension schemes. The employers subsidize half of the workers' contributions. The National Pension Corporation (NPC) under the Ministry of Health and Welfare directly controls national 
pensions.

Personal pension plans in Korea were first introduced in 1994. Insurance companies have been allowed to sell occupational pension plans since 1999. Commercial banks and investment-trust management companies have been permitted to market occupational plans as trust accounts since 2000.

Malaysia's main provident and pension funds are the Employees Provident Fund (EPF), the Pensions Trust Fund (PTF), the Social Security Organization (SOCSO) and the Armed Forces Fund (AFF). These are all government-managed asset pools, and the Central Bank of Malaysia (Bank Negara Malaysia) regulates the pension fund management industry. The Employees Provident Fund is by far the largest in Malaysia. It was established in 1951 and is governed by the 1991 EPF Act. All employees in Malaysia who have reached the age of 16 and are employed must be registered as a member of the Employees Provident Fund. The employer contributes 12 percent of the employee's wages and the employee contributes 11 percent of the monthly wages towards his or her pension account.

Private pension funds in Malaysia remain small. At present, Malaysians seeking additional retirement income usually invest in unit trusts (mutual funds) or life insurance policies.

Singapore's Central Provident Fund (CPF) that was established in 1955 as a mandatory, government-run retirement scheme and is the primary source of retirement funds. The CPF operates four types of individual accounts: (1) An ordinary account, to finance the purchase of a home, approved investments, CPF insurance, and education; (2) A special account, principally for old-age provisions; (3) A medisave account, to pay for hospital treatment, medical care, and approved medical insurance; and (4) From age 55 , a retirement account to finance periodic benefit payments starting at age 62 . Employees in Singapore contribute 20 percent of earnings if monthly earnings are over $S \$ 750 ; 0.6$ percent of the amount over $\mathbf{S} \$ 500$ if monthly earnings are between $\mathbf{S} \$ 500$ and $\mathbf{S} \$ 750$; and no contributions if monthly earnings are under $\mathbf{S} \$ 500$. The employer pays 16 percent of payroll if monthly earnings are $\$ \$ 50$ or over and provides no contribution for monthly earnings under $\$$ \$ 500. Maximum earnings for contribution purposes are $S \$ 4,500$ for both the employee and the employer.

The Singapore Supplementary Retirement Scheme (SRS) is a tax-advantaged voluntary scheme and was introduced in 2001. SRS permits Singapore citizens to save in a special individual account 15 percent of their total labor compensation. The Singapore government withdrew plans to introduce low-cost, voluntary private pension plans as a way to increase retirement savings. The decision in March 2005 followed consultations with pension fund experts and the public about the lack of industry incentives and the potential for investment losses under the proposed system.

Thailand's pension system consists of three basic components: (1) The Social 
Welfare Fund, a mandatory pay-as-you-go system covering virtually the entire private nonagricultural labor force of about 7.7 million workers with reserves of Tbt 242 billion (US $\$ 6.3$ billion); (2) The Government Pension Fund, covering approximately 2 million civil servants with reserves in excess of Tbt 240 billion (US $\$ 6.3$ billion); and

(3) Provident funds, covering 1.5 million workers in private companies and certain state agencies with reserves worth about Tbt 293 billion(US\$ 7.7 billion). A compulsory defined benefits old age pension scheme for private sector employees was introduced in Thailand on 31 December 1998. The scheme called "Old Aged Pension Fund" (OAPF) operates under the Thai Social Welfare Fund. The Social Security Act defines the combined contribution rate for old age pension and child allowance to be collected from 3 parties: employer, employee and the government, at a rate which altogether does not exceed 9 percent of wage (employer 4 percent, employee 4 percent and government 1 percent). The actual contribution rate for the old age pension is 8 percent - the employer contributes 3.5 percent, the employee contributes 3.5 percent, and the government contributes 1 percent. The Government Pension Fund (GPF) was established in 1997 for government employees and operates on a defined contribution basis. The GPF had 1.16 million members, and held assets worth Tbt 246.8 billion (US\$ 6.3 billion) at the end of 2004 making it the country's largest institutional investor.

There are two kinds of private pension funds in Thailand - provident funds and retirement mutual funds. The Provident Fund Act was promulgated in 1987 to encourage private sector employees to save for retirement. The fund is based on voluntary defined benefit system. A fund committee, comprised of employer and employee representatives, chooses the fund managers and oversees the provident fund. The provident fund is regulated by the Securities and Exchange Commission of Thailand (SEC). Employees and employers both contribute, and fund regulations currently allow public- and private-sector salaried workers to save up to Tbt 300,000 (US\$ 7,845) per year, or 15 percent of their monthly salary. The employee's contribution is 2-15 percent of the salary, and employers contribute at a level equal to or higher than the employee. If employers wish to contribute at a higher rate than 15 percent, they must seek approval from the Ministry of Finance.

The concept of the retirement mutual fund (RMF) was established in Thailand in March 2001, aiming to provide a means for voluntary retirement savings for employees not in the provident fund or who want to make the additional contributions.

\section{Pension Fund Size and Asset Allocation}

Public-sector pension systems are much larger in Asian countries compared to the private pension plans. They are heavily invested in government bonds and bank deposits. (Exhibit 22)

The Social Security Fund in China controlled about Rmb171.1 billion (US $\$ 20.7$ billion) in assets at the end of 2003, the latest data available. The scope of investment 
of the Social Security Fund is limited to bank deposits, treasury bonds and other financial instruments having acceptable liquidity, including tradable securities, investment funds, stocks, corporate bonds and financial institution bonds whose credit rating is above that of the issuer. Additional regulations introduced in 2001 allowed the Fund to invest up to 40 percent in equities and an additional 10 percent in corporate bonds. The revised rules also allocated at least 10 percent to bank deposits and a total of at least 50 percent to bank deposits and government bonds. In December 2002 the government picked six fund-management companies to manage the Social Security Fund. The six fund-management companies began investing in Chinese equities in June 2003.

China's Ministry of Labor and Social Security (MOLSS) issued regulations in 2004 to establish a framework for China's new system of voluntary corporate retirement plans to safeguard the investment of occupational pension fund assets. In 2005 MOLSS gave approval for 37 financial institutions to manage voluntary occupational pension funds under China's the Enterprise Annuity program. The first operating licenses were awarded 1n August 2005 to 15 Chinese investment managers, four of which are joint ventures with foreign companies. An additional 22 licenses were awarded to companies providing administrative services, such as custodians, trustees, and administrators.

Voluntary corporate pension plans (Enterprise Annuity) in China are intended to be fully funded, defined contribution individual accounts, subject to stringent oversight. The governance structure requires a plan trustee to oversee the pension fund and appoint a plan administrator, a custodian, and an investment manager. A separate license is required for each of these functions. Guidelines for enterprise annuity service providers to obtain operating licenses were issued in early February 2006. Enterprise annuity fund managers oversee the portfolio selection, and there is no employee choice. Investment restrictions require that at least 20 percent be invested in liquid assets (money market funds, for example); a maximum of 50 percent in fixed-income products and convertible bonds, including a minimum of 20 percent in government bonds; and a maximum of 30 percent in equities (stocks, mutual funds, and investment-linked insurance products). In addition, investment managers are be required to put 20 percent of administrative fees into a separate trust fund as a contingency against possible investment losses. At the end of 2005 China's voluntary pension plan assets stood at about Rmb 50 billion (US\$ 6.19 billion).16

In Indonesia, Jamsostek had membership of 23 million employees and assets of $\mathrm{Rp} 30$ trillion as of end-2004. In terms of asset allocation, equity investments comprised Rp 489 billion, bonds made up Rp14.1 trillion and other mutual fund investments made up Rp14.37 trillion. Taspen had Rp 9.59 trillion in funds under management as of May 2005. As of end-2003, net assets of private pension funds in Indonesia totalled Rp 49.8

${ }^{16}$ Source: www.ssa.gov - International Update, September 2005. 
trillion. Investment portfolios consist largely of bank deposits, bonds, short-term securities, real estate and mutual funds. Pension funds may invest all their funds in mutual funds - up to $10 \%$ of any pension fund's total investment is permitted in any single mutual fund. Investments in time deposits and certificates of deposit may be placed only with a bank that is neither the founder nor an affiliate of the founder of the pension fund, and pension funds are not permitted to invest offshore. Pension funds in Indonesia dominate investments in the national bond market by investing in corporate bonds and Bank Indonesia bills (SBIs). The rest of their funds are invested in the stock market. Pension funds can invest only 15 percent in affiliated companies. They are permitted to invest in commercial paper and bonds with a maturity of more than one year, but they can invest no more than $10 \%$ in companies or bonds listed for less than three years and cannot lend directly to firms. However, a pension fund can invest $100 \%$ of its funds in shares of companies that have been listed for three years or more.

The National Pension Corporation (NPC) in Korea had $17 \mathrm{~m}$ subscribers and W149.4 trillion (US\$145 billion) in total assets and W128 trillion (US\$124.2 billion) under management as of end-September 2004. In 1999 the NPC launched an in-house fund-management unit, with a group of professional managers hired from the private sector. The NPF is invested largely into three asset classes - public sector, financial and welfare. The principal public sector investment consist of treasury bonds, while financial sector instruments include the public and private bonds, stocks, beneficiary certificates, trust funds, and other types of securities. Assets in the welfare sector are establishment and operation of welfare facilities and loans to pension beneficiaries and for construction of welfare facilities for children and elderly people. As of endSeptember 2004, W8.3 trillion, or 6.5 percent, of NPF funds under management were allocated to public and welfare projects, and W118 trillion (US\$ 8.1 billion) were invested in financial market instruments of various kinds. Some W107.9 trillion (US\$ 104.7 billion), or 91.4 percent were invested in fixed-income securities, and another $7.8 \%$ were invested in stocks.

The NPC commissions a group of asset-management firms and investment advisors to manage public pension assets. In an effort to make public asset management more efficient, the Ministry of Budget and Planning launched an "investment pool management committee" in 2001. The committee, which consists of private- and public-sector experts, selects professional fund managers to operate public funds under outsourcing contracts and monitors their performance. As of endNovember 2004 some 16 firms were under outsourcing contracts to manage about US $\$ 4.2$ billion in public funds invested in the financial markets. A December 2000 amendment to the National Pension Act lifted a ban on investment in foreign securities, venture capital and exchange-traded derivatives.

There are no aggregate data for the private pension plans for Korea. The combined balance of occupational pension funds in insurance accounts and trust accounts stood at over W16 trillion (US\$15.5 billion) at end-June 2003. 
As of end-2004, there were 13 provident and pension funds in Malaysia, which managed assets totaling M\$291.3 billion (US\$ 76.9 billion). Competition in the Malaysian pension fund market is very limited. Overall, there were 21.2 million contributors to the provident and pension funds as of end-2004. The Employees Provident Fund (EPF) and SOSCO held a near duopoly in pension fund management, with 20.9 million contributors between them. The EPF held M\$240.3 billion (US\$ 63.3 billion) in assets - 82.5\%, of the total assets in the industry. EPF was also the largest institutional investor in Malaysia, owning around 8 percent of the total capitalization of the national stock market - and one of the largest pension funds in the world. The EPF maintains a $30 \%$ floor on investments in Malaysian government bonds and $20 \%$ ceilings in both equities and non-Malaysian assets. As a result, the EPF mainly invests in government securities. Of its $M \$ 248.6$ billion (US\$ 65.6 billion) in investments in 2005, $\mathrm{M} \$ 94.8$ billion (US\$25 billion) or $38.1 \%$ were invested in government securities, $\mathrm{M} \$$ 83.3 billion (33.5\%) in other types of Malaysian bonds, M\$48.2 billion (US\$21.98 billion) or $19.4 \%$ in equities, $M \$ 20.6$ billion (US\$ 5.43 billion) or $8.3 \%$ in money-market instruments and M\$1.8 billion (US\$ 480 million) or $0.7 \%$ in real estate (Exhibit 23). The fund also allocated $M \$ 1$ billion to private-equity investments, $M \$ 200 \mathrm{~m}$ of which was invested in eight companies as of end-September 2005. The Employee Provident Fund (Amendment) Act of 1996 allows EPF participants to invest some of their contributions in the capital markets via mutual funds/unit trusts. The government has appointed 25 Malaysian financial institutions as designated fund managers to handle these investments.

The investment option, which is limited to contributors by employees younger than 55 with savings exceeding $M \$ 50,000$, allows withdrawals of a maximum $20 \%$ of any surplus exceeding M\$50,000 for capital-market investment. In 2004 the EPF allocated M\$ 800 million (US\$ 211 million) to external fund managers, to be followed by M\$ 1.75 billion (US\$ 0.460 million) each year for 2005-07 - Exhibit 24. The EPF is also an active investor in the country's economic infrastructure. It was the single largest financier of the $M \$ 9$ billion Kuala Lumpur International Airport. To enable it to finance private-sector activity, the EPF Act was liberalized in 1991 to allow the EPF to channel up to $50 \%$ of its annual investable funds (up from $30 \%$ ) into private securities. The EPF can invest overseas only with the approval of the Ministry of Finance. In June 2005 the EPF appointed Aberdeen Asset Management, the first foreign fund manager to receive a license to operate in Malaysia, to manage its overseas investments, and in October 2005 it was seeking approval to invest as much as US\$ 1 billion in private-equity funds and fixed-income securities overseas.

Private pension funds are very small in Malaysia. Combined assets of private funds were $\mathrm{M} \$ 1.1$ billion at year-end 2004 .

In Singapore there were three million Central Provident Fund (CPF) members as of mid-2005, with a total balance of S\$ 114.9 billion (US\$ 69.54 billion) in their accounts. Under the CPF Investment Scheme (CPFIS) members can invest their Ordinary Account and Special Account savings. Under CPFIS-Ordinary Account (CPFIS-OA), 
members can invest up to $35 \%$ of savings (Ordinary Account balance plus net amounts withdrawn for education and investments) in shares, corporate bonds and property funds, while $10 \%$ can be invested in gold. As of September 2005, 25 percent of total CPF balances were invested in stocks and bonds, 63.4 percent in insurance policies, and 11,1 percent in unit trusts. CPF members earn a market-based interest rate on their savings, subject to a minimum rate of 2.5 percent (CPF Board, 2004). Funds in the Medisave, Special and Retirement funds earn an additional 1.5 percent, or 4 percent minimum per annum. The interest rate is a weighted average of the 12-month fixed deposit rate and saving rates at major banks. The weights are 80 percent and 20 percent respectively. Restrictions on investing in overseas markets were eliminated in 1998. The potential for international diversification is available only through unit-trusts.

In Thailand, the investment guidelines for the OAPF must comply with the regulations of the Social Security Subcommittee on Investment. The Subcommittee consists of employers, employees, government representatives and investment experts, and provides recommendations to the SSO, who then request approval from the Social Security Committee in compliance with the Ministry of Finance guidelines. In December 2003, size of the OAPF was about Tbt 117.39 billion. The assets of the OAPF are invested mainly in Thai bonds. Only 2.80 percent of the fund was invested in equities and 3.9 percent was invested in state owned enterprise equities. The major holdings are state enterprises and commercial banks $24 \%$, government and government guaranteed bonds $37.2 \%$, state enterprise bonds $10.7 \%$, and equities $6.7 \%$

The GPF must invest at least 60 percent of its portfolio in low-risk assets (cash, bank deposits, government bonds, investment grade bonds and securitized bonds) and 40 percent in high-risk assets (stocks and warrants, corporate debentures, mutual finds, real estate). There is a 20 percent limit on stocks, warrants and convertible debentures and a 10 percent limit on single company's stock, warrants and debentures. Like other Thai-based investors, the OAPF is not able to invest abroad directly. At end of 2003, the provident fund covered 1.41 million employees in 5,760 enterprises with total fund size of Tbt 287.3 billion (US\$ 7.2 billion). As of November 2005, the net asset value of provident funds was almost US\$ 8 billion.

Fund managers in Thailand provide a number of retirement mutual funds with various risk profiles, and the investor can switch assets between funds. As of December 2003, total RMF funds were Tbt 8.3 billion (US\$208.4 million). Private pension funds in Thailand are permitted to invest in real estate, mutual funds geared toward financialinstitution restructuring, property and loan funds, as well as derivatives. Investment in each of these types of funds is limited to $5 \%$ of the fund's net asset value, and total investment in all such funds must not exceed $15 \%$ of NAV.

The Thai Finance Ministry has announced plans to convert the existing framework of voluntary provident funds into a mandatory centralized system. The proposal is the latest in a series of efforts to encourage retirement savings and would provide additional coverage for low wage-earners. Details of the new system are 
expected to be announced in April 2006, with implementation set for later in 2006.17

\section{Summary}

Pension assets and the adequacy of old-age provisioning in the developing countries Asia have, in relative terms, outpaced those in many developed countries. First, they have relatively young populations and gradual aging, so that they have more time to develop pre-funded pension schemes without some of the friction burdens of countries with much older populations. Second, they are much less reliant on PAYG pension systems with high and possibly unsustainable promises to pension beneficiaries. Most systems are defined-contribution and therefore pre-funded, with systems like the Singapore CPF among the exemplars globally - although all such systems are prone to investment returns that may not meet expectations. Most also are controlled by the state and offer only limited portfolio discretion for pension plan participants, limited management by private asset managers, and limited choice of asset classes. Given that defined contribution pension systems represent key pools of investible assets in these countries, increased choice and competition among asset managers - as well as increased choice among asset classes - could make a significant contribution both the soundness of pension schemes and to capital market development.

\section{Contours of the Asset Management Industry: Private Clients}

One of the largest segments of institutionally-managed assets globally is related to high net-worth individuals and families, generally grouped under the heading of "private clients." Total funds under management have been estimated at over $\$ 70$ trillion in 2004 - significantly exceeding the size of the global pension asset-pool. Because of very different investment objectives and service requirements, private client wealth is usually segmented according to investible assets (not including real estate) under management (AUM) - as shown in Exhibit 25. Mass affluent, emerging wealthy and established wealthy categories are broken out separately, with the first category (assets of between $\$ 100,000$ and $\$ 1$ million) accounting for about two thirds of global AUM. Mass affluent investors' assets are usually deployed in bank deposits, certificates of deposit, traded financial instruments and to the extent they are managed on a fiduciary basis they tend to be found in the mutual funds and pension funds sectors, discussed earlier.

True private client AUM is therefore found in the segments denoted as "emerging wealthy" and "established wealthy" in Exhibit 25- accounting for anywhere between \$25 and $\$ 45$ trillion globally - depending on the data and AUM segments. It should be noted that data in this area are notoriously unreliable, since there is no systematic disclosure

${ }^{17}$ See www.ssc.gov - International Update. 
and data collection effort worldwide. Consequently, published data tends to be aggregated from small samples based on various assumptions. Bearing that caveat in mind, Exhibit 26 provides a rough estimate of the geographic location of global private wealth - with almost half arising in the Americas and about one quarter each in Europe and Asia - although growth is expected to be proportionately higher in the latter region, especially non-Japan Asia.

Exhibit 27 indicates estimated deployment of private client asset pools, in that case including real estate, for 2002 and 2003. According to these estimates, about $25 \%$ of investments are allocated to bonds, $10 \%$ to bank deposits, $36 \%$ to equities and $13 \%$ to alternative investments like hedge finds and private equities. The asset management industry would be active in all except the banking domain.

Private client asset management objectives are an amalgam of preferences across a number of variables among which liquidity, yield, security, tax-efficiency, confidentiality, and service-level are paramount. Each of these plays a distinctive role.

- $\quad$ Capital Preservation and Yield. Traditional private clients have been concerned with wealth preservation in the face of antagonistic government policies and fickle asset markets. Clients usually demand the utmost in discretion from their private bankers, with whom they sometimes maintain lifelong relationships initiated by personal recommendations. Such clients have to some degree given way to more active and sophisticated individuals. Aware of opportunity costs and often exposed to high marginal tax rates, they considered net after-tax yield to be far more relevant than the security and focus on capital-preservation traditionally sought by high net-worth individuals. They may prefer gains to accrue in the form of capital appreciation rather than interest or dividend income, and tend to have a much more active response to changes in total rate of return.

- $\quad$ Security. The environment faced by high net-worth investors is arguably more stable today than it has been in the past. The probability of revolution, war and expropriation has declined over the years in Europe, North America, the Far East and Latin America. Nevertheless, a large segment of the private banking market remains highly security-conscious. Such clients are generally prepared to tradeoff yield for stability, safety and capital preservation.

- $\quad T a x$-efficiency. Like everyone else, high net-worth clients are highly sensitive to taxation, perhaps more so as cash-strapped politicians target "the rich" in a constant search for fiscal revenues. International financial markets have traditionally provided plenty of tax-avoidance and tax-evasion opportunities ranging from offshore tax havens to private banking services able to sidestep even sophisticated efforts to claim the state=s share.

- $\quad$ Confidentiality. Secrecy is a major factor in private banking - secrecy required for personal reasons, for business reasons, for tax reasons and for legal or political 
reasons. Confidentiality, in this sense, is a "product" that is bought and sold as part of private asset management business through secrecy and blocking statutes on the part of countries and high levels of discretion on the part of financial institutions. The value of this product depends on the probability and consequences of disclosure, and is "priced" in the form of lower portfolio returns, higher fees, sub-optimum asset allocation, or reduced liquidity as compared with portfolios not driven by confidentiality motives. ${ }^{18}$

- $\quad$ Service level. While some of the tales of personal services provided for private banking clients are undoubtedly apocryphal, the "fringe benefits" offered to high net-worth clients may well influence the choice of and loyalty to a particular financial institution. Such benefits may save time, reduce anxiety, increase efficiency, or make the wealth management process more convenient. Personal service is a way for personal asset managers to show their full commitment to clients accustomed to high levels of personal service in their daily lives.

The essence of private banking is to identify accurately each client's unique objectives, and to have the flexibility and expertise to satisfy these as fully as possible in a highly competitive marketplace. On the assumption that the majority of funds managed by private banking vendors have not been accumulated illegally, the demand for financial secrecy relates mainly to matters of taxation and transfers of funds across borders. Tax issues will take much longer to deal with, and will probably always be a major driver of the international private banking industry. Consequently, private client assets are usually divided into "offshore" (assets deployed outside the country of residence of the investor) and "onshore" assets.

As Exhibit 28 suggests, in the mid-1990s about 2/3 of private client assets were estimated to be onshore and the balance (perhaps $\$ 6$ trillion) offshore. Exhibit 29 identifies the major motivations for maintaining offshore private banking accounts, as well as and the competitive basis of offshore private banking centers. Exhibit 30 notes the principal destinations for "offshore" managed assets, with Switzerland capturing a global market share of about one-third.

This is changing. The tax-haven status of Austria and Luxembourg has been constrained under fiscal pressure from EU partner countries, and the member states have come together some way on rules regarding personal taxation and disclosure of tax information. So the ability to conceal private wealth from tax collectors has diminished, as it already had in the United States, Japan and various other countries where tax evasion is a criminal offense and enforcement is vigorous. Even Switzerland, in its attempt to remain as a European haven for those intent on avoiding home-country taxation (as distinct from those committing fax fraud as defined under Swiss law) has

\footnotetext{
${ }^{18}$ See Ingo Walter, The Secret Money Market (New York: Harper Collins, 1990).
} 
been constrained by an agreement with EU member states to withhold taxes on capital income to the treasuries of countries of investor residence, as opposed to the alternative - disclosing their identities and account holdings. However, the use of shell companies, nominee accounts and other techniques appears to have limited the effectiveness of this approach.

The future of offshore private banking hinges on a number of issues that are likely to limit its growth. These include more effective tax coordination, cooperation and alignment among national authorities, tighter notification and reporting requirements imposed on banks dealing with suspect or under-regulated banks and countries, international agreements to expand account investigation related to money laundering and the financing of terrorism, including focus on accountants and lawyers, and the use of "cordons sanitaires" in the case of non-cooperating institutions and countries. Given these developments, most observers believe that the "offshore" component of private client asset allocation is likely to grow much more slowly than global private wealth as a whole, suggesting in terms of Exhibit 28 that the bulk of the growth is likely to come in the "onshore" domain.

If indeed private client wealth management in the future is likely to focus on the "onshore" sector, firms competing for this business will have to address a number of distinct client segments. These include:

- "Traditional" high net worth individuals and families require comprehensive advice on portfolio structures, proper inheritance planning and long-term investment strategies, with possible interest in global investing and trading opportunities.

- Entrepreneurs / Mittelstand represent the driver of wealth creation in most countries, and require integrated advice on matters of business finance and personal finance.

- Professionals and executives comprise self-employed professionals, partners in professional firms, financiers, and traders, highly-paid executives including those with stock options and share plans. They usually have complex and tax-driven compensation and asset-holding patterns, including multi-country requirements

- Others such as entertainers, artists, writers, sports professionals and others who have become seriously wealthy as a result of personal talent and effort, and who tend to focus on employment-related income generation and wealth accumulation, viewed as an "employment relationship asset."

- Financial intermediaries and external asset managers constitute another private client base, including family offices of the very wealthy. This seems to be a substantial and growing acquisition channel for clients that cannot be attracted directly, and includes accountants and law firms which deal with the wealthy. 
In the process, onshore private asset managers find it necessary to optimize across some sort of "value chain" such as that depicted in Exhibit 31, which breaks-out the key functions and shows how they are interrelated.

\section{Available Evidence on the Private Client Industry in Asia}

Data on asset management for private clients are extremely difficult to assemble on a coherent basis. Onshore wealth management data suffer from variations in wealth cutoffs separating "private" and "retail" assets under management, which are often specific to individual financial institutions. Offshore wealth management involves a high level of confidentiality, and there is little systematic data available from the financial intermediaries involved. Based on the estimates presented in Exhibit 26, however, roughly $\$ 2.3$ trillion of the $\$ 41$ trillion of total client assets in 2004 are estimated to arise in Asia, with disproportionate growth expected in the years ahead.

Assets under management (AUM) are not generally broken down for high net worth clients onshore domestically in the various countries, where definitional issues define the AUM cutoffs and data are generally undisclosed, and certainly not for offshore AUM where the drivers usually involve political or economic instability, tax evasion or avoidance, and similar motivations. Three locations, however probably account for the vast bulk of managed private client wealth in Asia - Japan, Singapore and Hong Kong. As China develops large pools of private wealth that need to be managed, it will join this group as well.

Most large local and foreign banks in Singapore maintain asset-management units that also serve as key distribution vehicles for asset-management firms serving high net worth investors. Singapore has a dominant position in serving the needs of private clients in the Southeast Asian region, one of the fastest growing in the world in terms of net new money inflows.

Hong Kong attracts high-net-worth individuals from around the region. Almost every major international bank doing business in the territory has a private banking division, seeking to cater to high-net-worth individuals with at least US\$1million to invest. All of the world's major private banks have operations in the Special Administrative Region (SAR). Such private banking activities were recorded at HK\$ 636 billion (US\$ 81.78bn) in 2004, of which 58 percent were sourced from Hong Kong investors and the rest from non-Hong Kong investors.

Asset management for private clients remains a minor financial activity in Indonesia. Most pension funds continue to be held by the state or private employers, although the growth of mutual funds should give rise to more professional management. Wealthy private individuals tend to hold substantial assets abroad, especially in Singapore. 
Commercial banks in Korea have been introducing the concept of private banking. According to the Bank of Korea, assets in private banking accounts amounted to W48.5trn at end-2003, or $17.4 \%$ of all household deposits. Wrap accounts, which allow money managers to offer and manage a group of investments in stocks, bonds and cash funds for a flat fee, received regulatory approval in September 2000. Only full service securities companies can handle wrap accounts, which must have at least W100m (US\$100,000) per personal account and W200m (US\$200,000) per corporate account. At least 30 percent of the assets in these accounts must be invested in highyield bonds. Cash management accounts (CMAs), a South Korean version of US money market mutual funds, pool funds from multiple investors. Investment in CMAs through short-term financing houses requires an initial minimum deposit of W4m (about US\$ 430). According to Morgan Stanley Research, 13 to 14 percent of the fees of Kookmin and Hana Banks came from wealth management services, for example.

Private banking in Malaysia is mostly offered by the larger domestic banks or by foreign banks such as HSBC, Standard Chartered Bank and Citibank. It is usually a premium service providing current accounts, safe-deposit boxes and complimentary credit-card memberships to selected customers. Major individual investors in Malaysia still turn to financial institutions in more mature and more liberal financial markets such as Singapore and Hong Kong to manage their assets.

Major local and foreign-based banks in the Philippines segment their individual clients to carve-out high net worth individuals. However, as in other developing countries in the Asian region, where the law permits wealthy private individuals tend to hold a substantial part of their assets overseas.

The traditional activities of Western-style asset-management firms targeting high net worth clients have not yet appeared in China. However, a number of foreign banks that are prominent in private banking have taken stakes in Chinese banks and securities firms, presumably with a view to building the private client business as serious wealth develops in China in the years ahead. Private banking in China has mostly focused on the management of offshore accounts for Chinese residents who have managed to establish a wealth position abroad, much of the activity occurring in Singapore, Hong Kong and Switzerland. Foreign private bankers might visit Chinese clients and suggest various investment alternatives abroad, but stay clear of the actual expatriation of funds for fear of running afoul of strict Chinese currency and tax regulations.

Domestically, Chinese wealth management was highly underdeveloped in terms of private banking services, asset allocation opportunities and limits on foreign investments. Given the WTO-induced liberalization of the activities of foreign banks in China at the end of 2006, major players such as UBS, Credit Suisse, HSBC and Citigroup will be able to accept deposits from wealthy individuals which can be channeled into higher-margin investment products. The banks' offshore client base has provided a useful platform for developing their onshore business in China, and to take 
advantage of the weak client-information systems and service capabilities of the local banks - although this should change before long due to joint ventures with foreign banks. The size of the private banking market in China is estimated to rise from $\$ \$ 825$ billion in 2004 to $\$ 1.606$ billion in 2009. ${ }^{19}$ Nevertheless, there appears a good deal of protectionist sentiment in China in favor of delaying the licensing of foreign private banks while domestic banks remain well behind in their ability to offer private client services.

\section{Some Country Specific Attributes of Asset Management in Asia}

A number of the countries in Asia have unique characteristics in terms of the structure of their asset management industries, sometimes related to the restructuring of their banking systems and specifically disposal of non-performing bank loans (NPLs).

\section{Hong Kong as a Continuing Regional Leader}

Hong Kong has the largest concentration of international fund managers in Asia. According to the 2004 Fund Management Activities Survey by the Securities and Futures Commission (SFC), the aggregate amount of assets in the combined fund management business reported by licensed corporations and registered institutions amounted to HK\$ 3,618 billion (US\$ 465.3 billion) at the end of 2004 - see Exhibit 32 . Institutional funds, non SFC-authorized funds, and pension funds have been the major types of funds managed, representing $39 \%, 24 \%$ and $15 \%$ of the total AUM of licensed corporations and registered institutions, respectively. SFC-authorized funds, private client funds and mandatory provident funds accounted for the remaining $22 \%$, as shown in Exhibit 33.

Hong Kong registered institutions provide a broad range of services in managing clients' portfolios of securities and/or futures contracts incidental to client-driven dealing in securities or derivatives. By geographical origin, non-Hong Kong investors remained the major source of funds, accounting for 83 percent of the advisory business - see Exhibit 34. The amount of assets advised in Hong Kong accounted for 63 percent of the total Asian advisory business in 2004 - see Exhibit 35 for the pattern of asset allocation and Exhibit 36 by type of asset managed.

\section{Singapore as the Leading Asset Management Center in Southeast Asia}

In addition to the strength of private client asset management in Singapore, it appears that institutional clients continue to account for about 46 percent of assets under management, with individuals and collective investment schemes each accounting for 27 percent. Equities accounted for 44 percent of assets under

${ }^{19}$ Boston Consulting Group, as cited in Financial Times, 12 March 2006. 
management, bonds for 22 percent, collective investment schemes for 6 percent, money-market assets for 17 percent, and alternative assets for 11 percent - see Exhibit 37. The average AUM of asset management entities was S\$2.3 billion (US $\$ 1.40$ billion) in 2004. There were 10 asset management entities managing more than $\$ \$ 10$ billion (US\$ 6.1 billion) in assets, accounting for 31 percent of total AUM. Asset managers with less than S\$1 billion (US\$ 610 million) in AUM numbered 132 in 2004, and accounted for 7 percent of total AUM. Most of these managers are indigenous companies - 111 in 2004. Indigenous asset management companies accounted for $25 \%$ and $38 \%$ of discretionary AUM and total employment of investment professionals respectively.

As of end-2004, total assets managed by Singapore-based financial institutions were reported to be $\mathbf{S} \$ 572.6$ billion (US $\$ 350$ billion) - see Exhibit 38 . With more than $70 \%$ of total AUM sourced from abroad, Singapore retained its role as an international asset management center. Asia-Pacific countries remained the main markets for Singapore-based asset managers in 2004, accounting for 46 percent of total funds sourced. 19.4 percent were sourced from Europe, 9 percent came from the United States, and the remaining 25.3 percent were from other markets. New high growth markets have emerged. Funds sourced from the Middle East and South Asia grew 76 percent and 53percent p.a. respectively in 2004.

\section{Competitive Dynamics in the Asset Management Industry}

To summarize, we have identified the key components of the "buy side" of financial markets - the asset management industry in terms of its principal domains. These are open-end and closed-end mutual funds, pension funds, fiduciary assets managed on behalf of foundations, endowments, central banks and other large assetholders, as well as assets managed on behalf of private clients. In the following sections of this paper, we will make come observational about competition among asset management firms, and finally develop some linkages between asset management and the development of efficient, resilient and robust capital markets in an emerging market context,

We have noted earlier that various kinds of financial firms have emerged to perform asset-management functions - commercial banks, savings banks, postal savings institutions, savings cooperatives, credit unions, securities firms (full-service firms and various kinds of specialists), insurance companies, finance companies, finance subsidiaries of industrial companies, mutual fund companies, hedge funds financial advisers and various others. Members of each strategic group compete with each other, as well as with members of other strategic groups. There are two questions. First, what determines competitive advantage in operating distribution gateways to the end-investor? Second, what determines competitive advantage in the asset management process itself? 
One supposition is that distribution of asset management services is both scopedriven and technology-driven. That is, asset management services can be distributed jointly with other types of financial services, and thereby benefit from cost economies of scope as well as demand economies of scope (cross-selling). Commercial banks may be able to cross-sell asset management services with banking products. Insurance companies may be able to cross-sell asset management services with insurance by incorporating: insurance features in asset management products - like fixed and variable annuities. Broker-dealers may be able to cross-sell asset management services with brokerage services and use broker networks to distribute funds, benefiting in the process from greater earnings stability and possibly captive buy-side placing power for securities. Nonfinancial corporations may be able to incorporate asset management services into in-house pension plan management and employee shareholder plans (ESOPs). For private banks, as noted, asset management is a key aspect of the private banking value-chain.

Such cross-links would tend to give retail-oriented financial services firms like commercial and universal banks, life insurance companies and savings institutions a competitive advantage in distribution. At the same time, more-specialized firms may establish cost-effective distribution of asset management services using proprietary remote-marketing techniques like the mails, telephone selling or the Internet, or by "renting" distribution through the established infrastructures of other financial intermediaries like banks, insurance companies or mutual fund supermarkets. They may also gain access through fund management consultants and financial advisers.

Asset management itself, of course, depends heavily on portfolio management skills as well as economies of scale, capital investment and technologies involved in back-office functions, some of which can be outsourced. Since fiduciary activities must be kept separate from other financial services operations that involve potential conflicts of interest, either through organizational separation or Chinese walls, there is not much to be gained in the way of economies of scope.

Inter-sectoral competition, alongside already vigorous intra-sectoral competition, is what makes asset management one of the most competitive areas of financial intermediation, even in the presence of rapid growth in the size of the market for asset management services. Certainly the dynamics of competition for the growing pools of defined benefit and defined contribution pension assets in various parts of the world, and its cross-linkage to the mutual fund business, has led to various strategic initiatives among fund managers. These include mergers, acquisitions and strategic alliances among fund managers as well as between fund managers, commercial and universal banks, securities broker-dealers, and insurance companies.

Market valuations of asset management companies have traditionally been quite high in comparison with other types of firms in the financial services industry, and this has been reflected in prices paid in M\&A transactions. Besides gaining access to distribution and fund management expertise, the underlying economics of this deal-flow 
presumably have to do with the realization of economies of scale and economies of scope, making possible both cost reductions and cross-selling of multiple types of funds, banking and/or insurance services, investment advice, high-quality research, etc. in a one-stop-shopping interface for investors despite a good deal of evidence that investors are quite happy to shop on their own with low-cost fund managers. Empirical evidence of either economies of scale or economies of scope in this sector is lacking, although the plausibility of scale economies exceed that for scope economies. In any event, there has been little evidence so far that M\&A activity in this sector has led to lower fees and charges to retail investors. ${ }^{20}$

In the private banking sector competition is also likely to intensify. Some will be offering very sophisticated products and perhaps lower costs than established private banks. Some will be offering innovative mutual funds or shares in limited partnerships, hedge funds, private equity investments or other special situations. Certainly there will be a profusion of both services and those offering them. Among the key competitive attributes of the leading asset management firms will significant distribution in leading markets, product breadth and consistency, global money management expertise, capital strength, technology investment capability and skills, marketing and customer service skills, low price and low-cost production, strong global brands, a strong clientoriented culture, cohesive senior management, and of course talented, motivated staff

Moreover, the field of competitive struggle will be in marketing just as much as it is in product development and investment performance. Such competition is bound to lower fees and commissions for private-client asset management, and the inherent strength of local financial firms' control over their high net worth clients will be tested.

\section{Asset Management and Capital Market Development}

The impact of the evolution of the asset management industry on Asian financial markets is likely to run the gamut from the composition of financial assets and the scope available for portfolio diversification to competition among financial centers as well as, importantly, transparency and corporate governance.

With perhaps three times the proportion of financial assets on the books of banks and other financial intermediaries - as compared with asset managers - than the United States, Asia will nevertheless go through much the same process of financial disintermediation that characterized the United States in the 1970s and 1980s, in the process reducing transactions and information costs (both heavily driven by technology) and making available new products to end-investors. This includes a range of financial instruments that are broadly available elsewhere in the world but that have been unable

\footnotetext{
${ }^{20}$ See Ingo Walter, Mergers and Acquisitions in Banking and Finance (New York: Oxford University Press, 2004).
} 
to reach critical-mass needed for trading efficiency and liquidity in some parts of Asia. Creation of efficient and resilient capital markets in emerging market countries generally, and Asia specifically, requires:

- Macroeconomic stabilization, a political commitment to market solutions, the existence of a viable banking system, and a basic law of property.

- Essential Legal Infrastructure, including basic principles of securities law, the concept of fiduciary responsibility, truth in new issues and effective due diligence, resistance to market manipulation including insider dealing and front running i.e., the customer comes first.

- A powerful and effective securities agency that combines independence, adequate enforcement powers with appropriate staffing and budgetary authority.

- A sensible tax basis of companies, including dividend and capital gains taxation, and efforts to undercut parallel financial markets.

- Essential governance infrastructure including a proper chartered accounting profession, sensible company law, identification of the proper role of boards of directors and their committees, ownership and shareholding structures, specification of voting rights and techniques of dispute settlement.

- Creation of appropriate financial instruments. At its core are sovereign bills and notes in various maturities, but beyond that non-sovereign fixed-income instruments must be launched alongside equities. This includes commercial paper issues and bonds of business enterprises, recapitalization of SOE debt, and debt issues of municipalities, all of which imply the establishment of independent debt rating agencies.

- On the equity side, creation of stocks as an asset class requires meaningful privatisation of state-owned enterprises, spinoffs and divestitures. IPOs of familycontrolled businesses and IPOs of start-ups. Usually privatizations are key to the development of viable equity markets as long as the resulting firms are competitively self-standing and independent of political interference.

- Emergence of a professional broker-dealer industry, including capital adequacy rules, management certification (fitness and properness), employee certification, terms for joint ventures with foreign firms and the role of securities activities in banks and universal banking. This also includes the creation of stock (and possibly bond) exchanges with appropriate trading techniques, price discovery, clearance and settlement infrastructure, and custody arrangements. And there must be viable policies toward foreign investors, including dependable decisions 
regarding any ownership limits, funds-only policies, differential share classes, and the like.

- Development of institutional investors, including mutual funds, pension funds, special-purpose funds, bank debt and equity portfolios, insurance company debt and equity portfolios, and specification of the role of core shareholding and corporate interlocks.

All of this institution-building requires a deliberate process that depends critically on the time schedule for implementation, training people for financial sector employment, building industry support infrastructures. adoption of accounting standards, developing an accounting profession, building competence in corporate and securities law, creating dispute settlement and arbitration processes and (perhaps not least) encouraging the use of the English language. The process is much like completing a complex architectural project, with careful scheduling and sequencing as important as the design components themselves.

\section{Impact on Financial Market Competition}

Given their size and the performance pressures bearing on them, institutional asset managers try to focus their trading on financial markets that are marked by the following characteristics:

- A high degree of liquidity, notably for block trades, and good after-hours capabilities.

- Low transactions costs, notably for commissions and spreads, clearance and settlement services, back-office operations, custody services, telecommunications and other financial infrastructure services.

- High levels of transparency in securities transactions and in the securities themselves, including strong regulatory and enforcement capabilities to ensure honest dealing and a level playing field.

- $\quad$ A broad product range of underlying securities and derivatives, and strong innovative capabilities.

- A uniform accounting and legal infrastructure that meets global standards.

- A major equities component of capital markets (of key interest to both pension funds and mutual funds), running from large-cap global companies to IPOs and private equity, with strong turnover and deep investor participation. 
The Asian countries today maintain highly fragmented systems of fixed-income, stock and derivatives markets, among which only Hong Kong and Singapore come close to meeting the needs of major institutional asset managers and their probable future evolution. In the presence of electronic links and low-cost transactions services to institutional investors, this fragmentation should disappear over time Certainly, the battle among Asian financial markets will be heavily affected by the behavior of highly performance-oriented asset managers. One would expect their selection of trading venues to gradually promote a shakeout among competing markets based on how they meet the aforementioned criteria.

It is worthwhile noting that the large, integrated US financial market supports only one major equity exchange, and one major OTC trading system, alongside a number of specialist exchanges plus various electronic exchanges. The U.S. "equilibrium" market structure may represent an inappropriate indicator for a future Asian financial market structure supporting the rapidly growing needs of institutional asset managers, although the dynamics do suggest that a reasonably coherent market mosaic will eventually develop. For example: (1) A single wholesale market for transactions-execution; (2) Dispersed asset management centers and perhaps no identifiable centers at all in a business where the necessary information, interpretation and transactions services can all be delivered electronically and in real-time; and (3) Specialist centers focusing on particular financial instruments that have their roots in history or ongoing economic developments.

\section{Institutional Asset Managers and Corporate Governance}

Assuming the progressive advance in prominence of institutional asset managers follows along the lines suggested in this paper, the capital markets will increasingly be the major source of external financing for Asian companies in the future - as against the traditional, heavy reliance on bank finance for debt and bank and corporate long-term shareholdings for equity. Fiduciary asset pools managed against performance benchmarks by mutual funds and pension funds will create increasingly fluid sources of capital for industry, and a fundamental shift should develop in the accountability of management and monitoring of corporate performance in Asia. In such a system, industrial restructuring will increasingly be triggered by the emergence of a control premium between the existing share price of a corporation and the value that an unaffiliated acquirer (whether an industrial company or an active financial investor) perceives could be unlocked by changes in management strategies or policies. Institutional asset managers often play a critical role in such scenarios. They may agree that a control premium does indeed exist and themselves begin purchasing shares, thereby placing still greater pressure on management of the target company. ${ }^{21}$

${ }^{21}$ For a comparison between traditional market-based and institution-based approaches to corporate control, see Jonathan Story and Ingo Walter, The Politics of European Financial Integration (Manchester: 
Even in the absence of a potential acquirer putting the company in play, major institutional asset managers who, because of their size or portfolio constraints, find it difficult or impossible to dispose of their ownership interest in a company they feel is performing poorly can request a meeting with management about the firm's strategy, financial performance, and realization of shareholder value, and perhaps speak-out at annual general meetings. Concerns about unwanted takeover efforts and institutional investor dissatisfaction may in turn prompt management to undertake a selfrestructuring, seek an acceptable merger partner (white knight), pay-out special dividends or initiate share repurchases, or find other ways to enhance shareholder value and efficiency in the use of capital to preclude the emergence of a control premium and hostile action.

The assessment of selected Asian countries with respect to the key governance variables related to disclosure and transparency in Exhibit 39 shows most at the bottom end of the ranking, suggesting poor governance practices overall, as depicted in Exhibits 40 and 41 . A transition from the traditional corporate governance process in many of the Asian countries with non-independent boards and large, friendly ownership positions - often linked to family holdings - which insulate management from the pressure of external shareholders seeking improved total returns to a more "contestable" model is an important possible consequence of the growing role of professionally managed asset pools. The potential benefits of such developments involve reduced cost-of-capital through higher share prices and improved access to global financial markets and a greater capacity for restructuring national economies in response to changes in technology, market competition and other fundamentals.

An Asian transition to an investor-driven, market-based capital-allocation process will require much higher levels of transparency in corporate accounting and disclosure than has been the norm in most countries, together with greater reliance on public information provided by management and systemic surveillance by research analysts working aggressively on behalf of investors. It implies arm's length financing on commercially viable terms by banks and financial markets, with financial institutions active in giving strategic and financial advice and sometimes taking transitional, nonpermanent equity positions in (and occasionally control of) corporations in the process of restructuring.

It also assumes that the principal stakeholders in corporations (shareholders, employees, managers and customers) accept that the central claim to legitimacy of free, investor-driven capital markets is that they generally provide the most efficient way of

Manchester University Press, and Cambridge: MIT Press, 1997). See also Roy C. Smith and Ingo Walter, Governing the Modern Corporation (New York: Oxford University Press, 2006). 
augmenting economic wealth, as against less viable politically-driven allocation of capital. This approach assumes that government will not prove a light touch for corporate lobbies seeking to avoid restructurings or takeovers through access to the public purse as a less demanding and less disciplined source of capital. The labor market likewise needs to be supportive, so that work-forces can be adapted and reallocated both functionally and geographically with the minimum of friction.

To the extent that the growth of large, properly regulated and increasingly performance-oriented pools of managed assets grow disproportionately as part of the Asian financial landscape, the implications for corporate governance and economic restructuring is likely to be inescapable.

\section{Summary and Conclusions}

The focus of this paper has been the structure, conduct and performance of the asset management industry, with special reference its evolution in the context of the Asian economies. The industry was positioned in a domestic and global flow-of-funds framework as "collective investment vehicles," with emphasis on its three principal components - mutual funds and hedge funds, pension funds and assets under management for high net-worth individuals - and their interlinkages. Evolution of the three asset management domains were then linked to the development of Asian capital markets and the process of corporate governance and economic restructuring. Several conclusions can be drawn.

First, the asset management industry in Asia is likely to grow substantially in the years ahead. Institutionalization and professional management of household discretionary assets through mutual funds has probably run its course for the time being in terms of market share some countries but has barely begun in many of the Asian countries that have traditionally been dominated by bank assets. Demographic and structural problems in national pension systems will require strong growth in dedicated financial asset pools as pay-as-you-go systems become increasingly unsupportable fiscally, and alternative means of addressing the problem show themselves to be politically difficult or impossible to implement as a matter of global concern. There are, however, substantial differences of view as to the timing of these developments within national environments, since pension reform is politically difficult to carry out and the political willingness to do so is difficult to predict. In both mutual funds and pension funds, and their linkage through participant-influenced defined contribution pension schemes, the center of global growth is likely to be highly intense in the near-term in Western Europe and then shift to Asia in the medium term.

Second, proliferation of asset management products will no doubt increase in Asia as financial markets become more fully integrated. Among Asian asset managers, there will no doubt be a great deal of jockeying for competitive position and in some cases changing levels of concentration, especially in the fast-growing pension fund 
sector, as new players are allowed to enter. There may also be consolidation in some markets in view of the importance of economies of scale in fund management and fund distribution. However, as in the United States the role of fund supermarkets, low-cost distribution via the Internet, as well as a large contingent of universal banks, insurance companies and foreign fund management companies is likely to prevent market structure from becoming monopolistic to any significant degree. Fund performance is likely become a commodity in some markets, with few differences among the major players and the majority of actively managed funds underperforming the indexes. This implies a competitive playing field that will be heavily conditioned by branding, advertising and distribution channels.

Third, despite the prospects for rapid growth the asset management industry in Asia is likely to be increasingly competitive. In addition to normal commercial rivalry among established local players in each country, the larger markets should be aggressively targeted by foreign suppliers of asset management services. Natural barriers to entry in the asset management industry - which include the need for capital investment in infrastructure (especially in distribution and backoffice functions), human resources (especially in portfolio management), technology, and the realization of economies of scale and scope - are not excessively difficult for newcomers to surmount. So the degree of internal, external and inter-sectoral competition in this industry is likely to promote market efficiency for the benefit of the end-users in managing discretionary household asserts, pension funds, the wealth of high net-worth individuals, and other types of asset pools.

Fourth, the evolution of the Asian institutional asset management industry will have a major impact on financial markets. The needs of highly performanceoriented institutional investors will accelerate the triage among competing debt and equity markets in favor of those that can best meet their evolving requirements for liquidity, execution efficiency, transparency, and efficient regulation. In turn, this will influence where firms and public entities choose to issue and trade securities in their search for cost-effective financing and execution. At the same time, the growing presence of institutional investors will increase the degree of liquidity due to their active trading patterns, create a ready market for new classes of securities, and enhance opportunities for the sales and trading activities of banks and securities firms, and for the role of product development and research in providing useful investment ideas.

Fifth, cross-border asset allocation will grow disproportionately as a product of institutional investors' search for efficient portfolios through international portfolio diversification (IPD). This is inherently a global process, so that the gains will depend on intermarket correlations of interest rates, exchange rates, equitymarkets and other asset classes worldwide. 
Sixth, the development of a deeper and broader capital market in Asia, spurred by the development of the institutional asset management industry, will have a bearing on the market for corporate control in some of the Asian economies - into a much more fluid one focused on financial performance and shareholder value. This should facilitate economic restructuring and creating industries that are encouraged to disengage from uncompetitive activities through the denial of capital and at the same time promoting leading-edge industries though venture capital and other forms of start-up financing. Such a transformation will hardly be painless, and will depend critically on political will and public support for a more market-driven growth process.

Finally, developments in institutional asset management will pose strategic challenges for the management of financial institutions in extracting maximum competitive advantage from this high-growth sector, in structuring and motivating their organizations, and in managing the conflicts of interest and professional conduct problems that can arise in asset management and can easily cause major problems for the value of an institution's competitive franchise. The fact that institutional asset management requires a global perspective, both on the buy-side and on the sell-side, reinforces the need to achieve a correspondingly global market positioning for a few major financial institutions, although technology and the changing economics of distribution virtually assures the survival of a healthy cohort of asset management boutiques and specialists.

In quantitative terms the effects of professional asset management on the buy-side of the fixed income market certainly dominates its overall impacts. Fixed income securities - extending across the maturity spectrum from commercial paper to long-term bonds and across the credit spectrum from the highest investment grades to junk - represent the closest alternative to financial intermediation via the banking system. And because fixed-income instruments are marked to market (unlike bank loans) the emergence of broad and liquid bond markets in developing countries contributes transparency, liquidity, improved monitoring and market discipline not otherwise possible. They also represent the "second channel" of financial intermediation which allows greater robustness and systemic protection for financial systems that have frequently been derailed by banking crises. Accordingly, the rise of fixed-income markets in Asia from 4.3\% of GDP in 1997 to $7.1 \%$ in 2005 (albeit with high inter-country variance) ${ }^{22}$ is an encouraging development that has required commensurate creation and growth of professionally managed fixed-income portfolios.

There remain a number of limitations to the contributions of asset management to the development of capital markets in Asia: (1) The scarcity of corporate bond issues, often limited to a few large companies, which needs to be extended through the credit spectrum to more risky, medium-size issuers with

\footnotetext{
${ }^{22}$ International Monetary Fund, Global Financial Stability Report (Washington, D.C.: IMF, 2005).
} 
"investibility" limited by poor investor protection and bankruptcy laws, disclosure and corporate governance, all of which are critical in meeting the needs of fiduciaries; (2) Government restrictions on corporate securities issues and control of the "calendar," in effect rationing capital market access and limiting supply; (3) Securities issuing costs, including credit rating costs, registration and underwriting fees, taxes and time requirements in bringing issues to market; (4) Lack of secondary market liquidity, with large bid-offered spreads, small issue sizes and occasional one-sided markets associated with bunching of asset-holdings in the hands of a small number of institutional investors; (5) Limited availability of trading data, limiting price discovery and ability to mark portfolios to market; (6) Absence of hedging vehicles and derivatives markets, limiting the ability for institutional investors to hedge and constraining interest in the underlying securities. Addressing each of these limitations will be key to the contribution of institutional asset management to efficiency and growth in Asia going forward. 


\section{References}

Asher, Mukul G., Newman David D. (2002). "The Challenge of Social Security Reform in Transition Countries: The Case of China," International Center for Pension Research, Research Report Number 3-2002.

Asher, Mukul G (2002) "The Role of Global Economy in Financing Old Age: The Case of Singapore," International Center for Pension Research, Research Report Number 2-2002.

Asset Management Association of Korea, (2005). "Trends in Investment Trusts in Korea," First Half of 2005.

Asset Management Association of Korea, (2005). "Trends in Investment Trusts in Korea," September 2005.

Bank of Korea (2002). "Financial System in Korea", Bank of Korea Research Department.

Bank of Korea (2005). "Financial Stability Report,) October 2005.

Bank Negara Malaysia, 2002. "Financial Sector," BNM 2002 Annual Report.

Bank Negara Malaysia, 2002. "Financial Sector," BNM 2004 Annual Report.

Bapepam, (2004). "2004 Annual Report"

Beh, Ai-Gek and Abonyi, George (2000) "Structure of the Asset Management Industry: Organizational Factors in Portfolio Investment Decisions," Visiting Researcher Series, No:14.

Chordia, Tarun. AThe Structure of Mutual Fund Charges, @ Journal of Financial Economics, June 1996.

Economist Intelligence Unit, China Country Finance, August 2005.

Economist Intelligence Unit, Hong Kong Country Finance, January 2005.

Economist Intelligence Unit, Indonesia Country Finance, November 2005.

Economist Intelligence Unit, Malaysia Country Finance, November 2005.

Economist Intelligence Unit, Singapore Country Finance, September 2005.

Economist Intelligence Unit, South Korea Country Finance, February 2005.

Economist Intelligence Unit, Philippines Country Finance, October 2005. 
Economist Intelligence Unit, Thailand Country Finance, March 2005.

Epstein, Neil, and Bruce R. Brewington, The Investment Management Industry in the United States (New York: Putnam, Lovell \& Thornton, 1997).

Gruber, Martin J. AAnother Puzzle: The Growth of Actively Managed Mutual Funds, Presidential address presented at the American Finance Association, San Francisco, January 1996, Journal of Finance, May 1996.

Holzmann, Robert. Pension Reform, Financial Market Development and Economic Growth: Preliminary Evidence from Chile, (Washington, D.C.: IMF Working Paper 96/94, August 1996).

Hurley, Mark P., Sharon I. Meers, Ben J. Bornstein and Neil R. Strumingher. The Coming Evolution of the Investment Management Industry: Opportunities and Strategies (New York: Goldman Sachs \& Co., 1995)

Longin, François and Bruno Solnik. Als the Correlation of International Equity Returns Constant?@ Journal of International Money and Finance, Vol. 14, No. 1, 1995.

Neave, Edwin. The Economic Organization of a Financial System (London: Routledge, 1992).

Patel, Jayendu, Richard J. Zeckhauser and Darryll Hendricks. Alnvestment Fund Performance: Evidence from Mutual Funds, Cross-Border Investments, and New Issues,@ in Ryuzo Sato, Richard Levich and Rama Ramachandran, Japan, Europe and International Financial Markets: Analytical and Empirical Perspectives (Cambridge: Cambridge University Press, 1994).

Reid, Brian, and Jean Crumrine, Retirement Plan Holdings of Mutual Funds, 1996 (Washington, D.C.: Investment Company Institute, 1997).

Sittampalam, Arjuna. Coming Wars in Investment Management (Dublin: Lafferty Publications, 1993).

Smith, Roy C. and Ingo Walter. Global Banking, Second Edition. (New York: Oxford University Press, 2003).

Turner, John and Noriyasu Watanabe. Private Pension Policies in Industrialized Countries (Kalamazoo: W.E. Upjohn Institute for Employment Research, 1995).

Warther, Vincent A. AAggregate Mutual Fund Flows and Security Returns, @ Journal of Financial Economics, September 1995. 
Berger, Allen N., Diana Hancock and David B. Humphrey,1993. "'Bank Efficiency Derived from the Profit Function," Journal of Banking and Finance, April.

Berger, Allen N. and T.H. Hannan, 1996. "Using Measures of Firm Efficiency to Distinguish Among Alternative Explanations of the Structure-Performance Relationship," Managerial Finance, October.

Berger, Allen N. and David B. Humphrey, 1992. "Megamergers in Banking and the Use of Cost Efficiency as an Antitrust Defense," The Antitrust Bulletin, 37.

Berger, Allen N., William C. Hunter and Stephen J. Timme, 1993."The Efficiency of Financial Institutions: A Review of Research Past, Present and Future," Journal of Banking and Finance, April.

Berger, Allen N. and L. Mester, 1997. "Inside the Black Box: What Explains Differences in the Efficiencies of Financial Institutions?" Journal of Banking and Finance, 21.

Berger, Philip G. and Eli Ofek, 1995. "Diversification's Effect on Firm Value," Journal of Financial Economics, 37.

Boyd, John, Stanley Graham, and R. S. Hewitt, 1993. "Bank Holding Company Mergers with Non-bank Financial Firms: Effects on the Risk of Failure," Journal of Financial Economics, 17.

Brown, Stephen J. and Jerold B. Warner, 1985. "Using Daily Stock Returns: The Case of Event Studies," Journal of Financial Economics, 14.

Cummins, J.D. and H. Zi,1998. "Comparisons of Frontier Efficiency Levels," Journal of Productivity Analysis, June.

DeLong, Gayle, 2001. "Stockholder Gains From Focusing Versus Diversifying Bank Mergers," Journal of Financial Economics, 59.

Demsetz, Rebecca S., Marc R. Saidenberg and Philip E. Strahan, 1996. "Banks with Something to Lose: The Disciplinary Role of Franchise Value," Federal Reserve Bank of New York Policy Review, October..

Goldberg, L.G., G.A. Hanweck, M. Keenan and A. Young, 1991. "Economies of Scale and Scope in the Securities Industry," Journal of Banking and Finance, 15.

Houston, J., C. James, and M. Ryngaert, 1999. "Where Do Merger Gains Come From? Bank Mergers From the Perspective of Insiders and Outsiders," Working Paper, University of Florida, Gainesville. 
Houston, J. and M. Ryngaert, 1994. The Overall Gains From Large Bank Mergers," Journal of Banking and Finance, 18..

John, Kose and Eli Ofek, 1995. "Asset Sales and Increase in Focus," Journal of Financial Economics, 37.

Kane, E., 2000. "Incentives for Banking Megamergers: What Motives Might Regulators Infer from Event-Study Evidence?" Journal of Money, Credit, and Banking, Vol. 32, August.

Kanjanaphoomin, Niwat (2004) "Pension Fund, Provident Fund and Social Security System in Thailand," International Conference on Pensions in Asia: Incentives, Compliance and Their Role in Retirement.

Kroszner, R. and R. Rajan, 1994. "Is the Glass-Steagall Act Justified? A Study of the U.S. Experience with Universal Banking Before 1933," American Economic Review, 84.

Lipper Funds, China Fund Market Year-end Summary, December 31,2005.

Lipper Funds, Malaysia Fund Market Year-end Summary, December 31,2005.

Lipper Funds, Singapore Fund Market Year-end Summary, December 31,2005.

Lipper Funds, Thailand Fund Market Year-end Summary, December 31,2005.

Lang, G. and P. Wetzel,1998. "Technology and Cost Efficiency in Universal Banking: A Thick Frontier Approach," Journal of Productivity Analysis, 10.

Monetary Authority of Singapore (2004) "2003 Survey of the Singapore Asset Management Industry," Financial Centre Development Department, 17 June 2004.

Monetary Authority of Singapore (2005) "2003 Survey of the Singapore Asset Management Industry," Financial Centre Development Department, July 2005.

OECD (2005) "Pension Markets in Focus," OECD Newsletter, June 2005, Issue .

O'Hara, M. and W. Shaw, 1990. "Deposit Insurance and Wealth Effects: The Value of Being 'Too Big to Fail'” Journal of Finance, 45.

Philippines Securities and Exchange Commission (2004) "2004 Annual Report".

Puri, M., 1996. "Commercial Banks in Investment Banking: Conflict of Interest or Certification Role?" Journal of Financial Economics, 40. 
Santomero, A. and E. J. Chung, 1992. "Evidence in Support of Broader Bank Powers," Financial Markets, Institutions, and Instruments, 1.

Saunders, Anthony, 2000. Financial Institutions Management: A Modern Perspective, Third Edition (Burr Ridge, Ill.: Irwin).

Saunders, Anthony and Ingo Walter, 1994. Universal Banking in the United States (New York: Oxford University Press).

Securities Commission of Malaysia (2004). 2004 Annual Report.

Siems, Thomas F., 1996. "Bank Mergers and Shareholder Value: Evidence from 1995's Megamerger Deals," Federal Reserve Bank of Dallas Financial Industry Studies, August.

Singapore Central Provident Find Board (2004). "2004 Annual Report"

Smith, Roy C. and Ingo Walter, 1997. Street Smarts: Linking Professional Conduct With Shareholder Value in the Securities Industry (Boston: Harvard Business School Press).

Smith, Roy C. and Ingo Walter, 2003. Global Banking, Second Edition (New York: Oxford University Press).

Smith, Roy C. and Ingo Walter, 2006. Governing the Modern Corporation (New York: Oxford University Press).

Social Security Schemes of ASSA Member Countries, 1998, Kuala-Lumpur.

Stefanadis, Chris, 2002. "Specialist Securities Firms in the Gramm-Leach-Bliley Era. Federal Reserve Bank of New York. Working Paper.

Stock Exchange of Thailand (2005). "2004Thailand Securities Fact Book."

Thailand Association of the Investment Management Companies, (2005) "Fund Performance Report, December 2004."

US General Accounting Office, 1991. "Deposit Insurance: Overview of Six Foreign Systems" Washington, D.C.: GAO/NSIAD-91-104.

Walter, Ingo ,1988. Global Competition in Financial Services (Cambridge: Ballinger-Harper \& Row).

Walter, Ingo, 1998. "Universal Banking: A Shareholder Value Perspective," Schriftenreihe des Instituts fuer Kapitalmarktforschung as der Johann Volfgang 
Goethe-Universitaet, Frankfurt am Main, Germany, 42.

Walter, Ingo, 2002. "Financial Integration Across Borders and Across Sectors: Implications for Regulatory Structures," in Jeroen Kremers, Dirk Schoenmaker and Peter Wierts, Financial Supervision in Europe (London: Edward Elgar Publishing Ltd.

Walter, Ingo, 2003a. "Strategies in Financial Services, the Shareholders and the System: Is Bigger and Broader Better?" in Robert Litan and Richard Herring (Editors), Financial Conglomerates (Washington, D.C.: The Brookings Institution).

Walter, Ingo. 2003b "Conflicts of Interest and Market Discipline Among Financial Services Firms." Paper presented at a Federal Reserve of Chicago - Bank for International Settlements conference on "Market Discipline: Evidence Across Countries and Industries," October 30 - November 1, 2003.

Walter, Ingo, 2004. Mergers and Acquisitions in Banking and Finance - What Works, What Doesn't and Why (New York: Oxford University Press).

Wang, Xin (2001). "China's Pension System Reform and Capital Market Development," International Conference on China and WTO, Kennedy School, Harvard University. Wells, Stephen (200?) "Moving Toward Transperancy: Capital Market in Indonesia," ADB Report.

Werner, Richard A. (200?) "Capital Market in Thailand: Issues and Opportunities" ADB Report.

Yu, Li, 2001. "On the Wealth and Risk Effects of the Glass-Steagall Overhaul: Evidence from the Stock Market," Working Paper, New York University. 


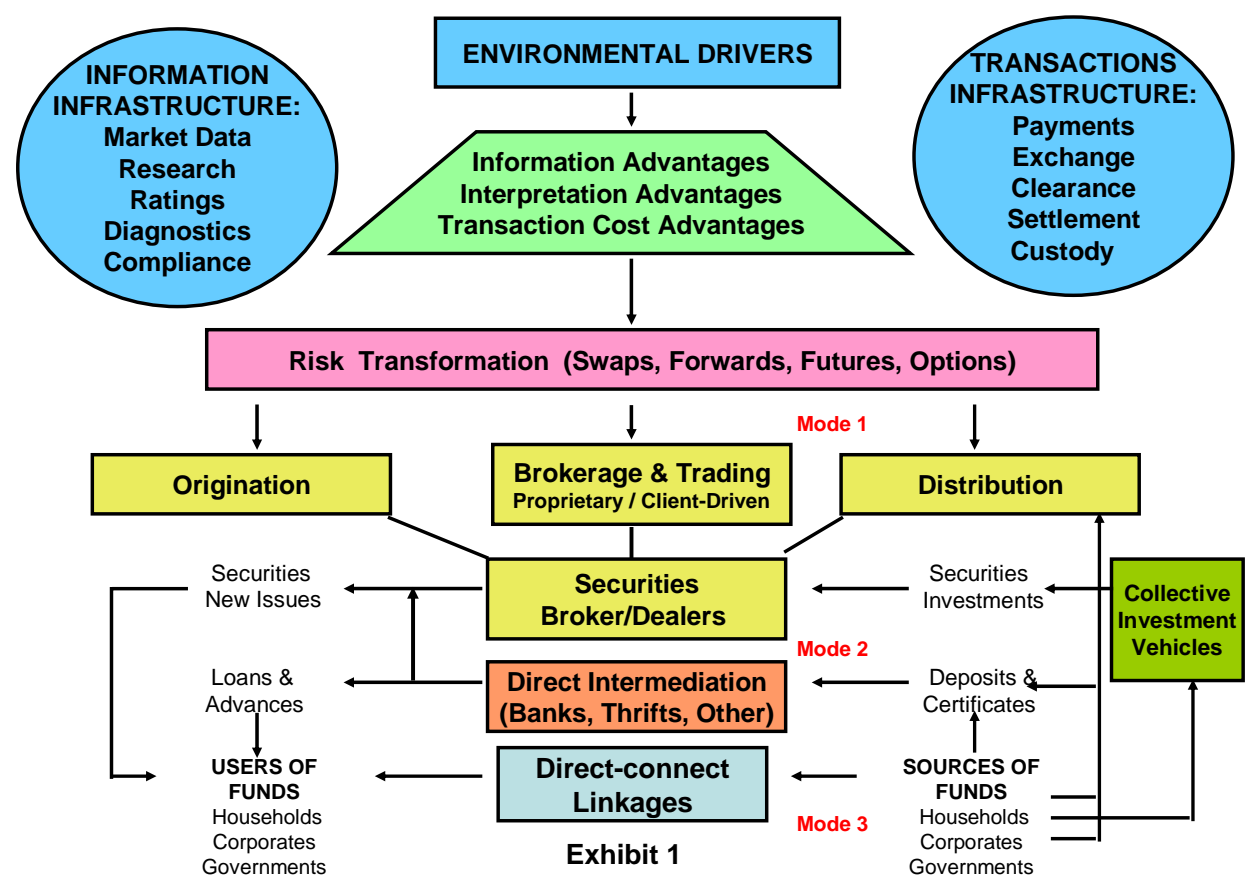

Source: Roy C. Smith and Ingo Walter, Global Banking, Second Edition (New York: Oxford University Press, 2003).

Exhibit 2

Global Capital Market Growth vs. GDP Growth

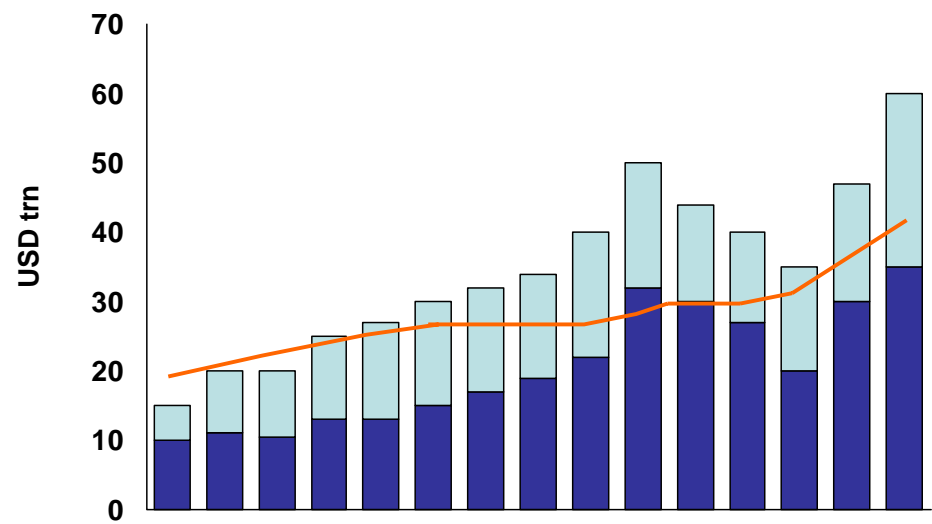

$\begin{array}{lllllllllllllll}90 & 91 & 92 & 93 & 94 & 95 & 96 & 97 & 98 & 99 & 00 & 01 & 02 & 03 & 04\end{array}$ CAGR $=10.5 \%\left\{\begin{array}{l}\square \text { Global Bond Market Value } \\ \text { Global Equity Market Capitalisation }\end{array}\right.$

Source: World Federation of Exchanges, World Bank Global GDP CAGR = 4.99 
Exhibit 3

COMPOSITION AND GROWTH OF THE GLOBAL

FINANCIAL STOCK (GFS), 1980-2010

$\$$ Trillions; percent

Fitugese dett securites

Povemmert ceot mesurlies

Bank depos:s

1993-2003 CAGR

Percent

8.4

8.6

27

10.2

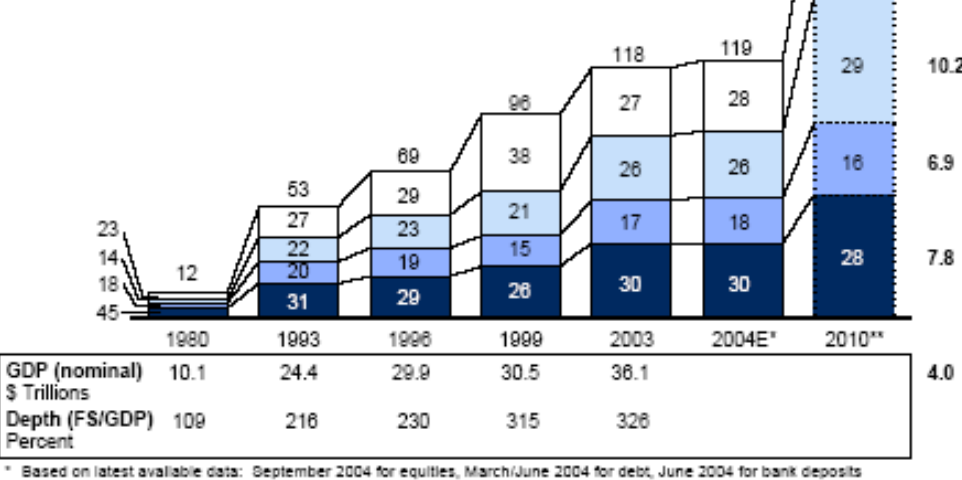

- Based on Iateat aval abje dats: Oeptember 2004 for equities, March /June 20

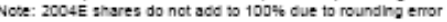

Source: MeKhnsey Global lingthte Global Financlal atock Database; Worid Federstion of atock Exchanges; Merrll Lynch; Gobal Inalght

\section{Exhibit 4}

GEOGRAPHIC COMPOSITION OF THE GLOBAL

FINANCIAL STOCK BY ASSET CLASS

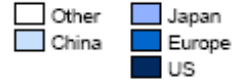

Percent

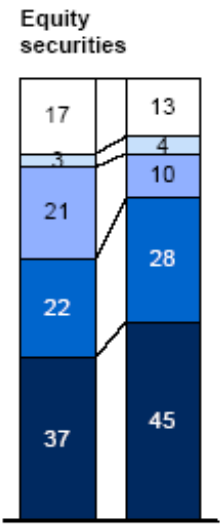

Private debt

securities

Government

debt securities

Bank deposits
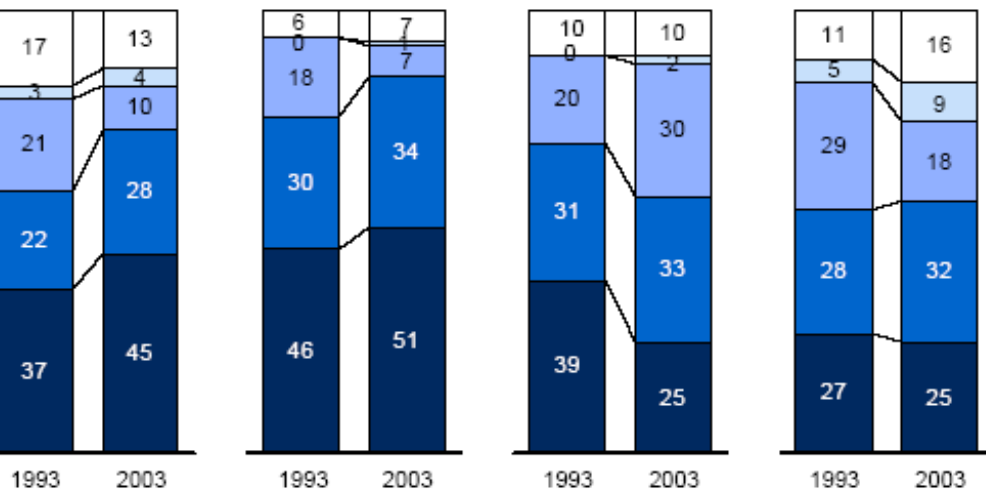

19932003

Source: McKInsey Global Institute Global FInanclal Stock Database 
Exhibit 5

Asset Composition - Mexico 1996-2005

(billion pesos)

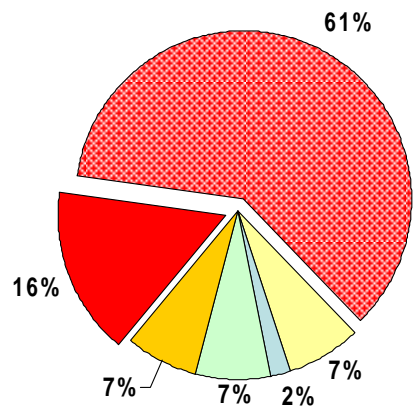

Dec '96 $\square$ Demand D.

图 Time D.

$\square$ Securities

$\square$ Insurance

$\square$ Afore

$\square$ Mutual Funds

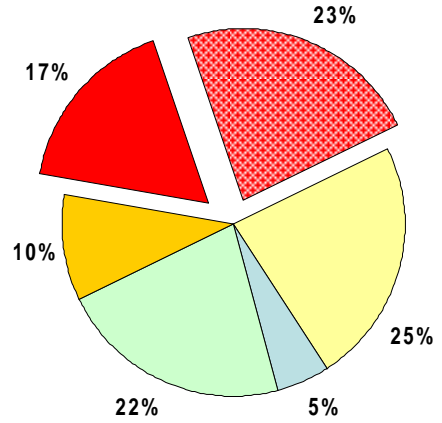

Jun ‘05

4,271

Exhibit 6

REGIONAL DIFFERENCES IN FINANCIAL STOCK COMPOSITION, 2003

$\$$ Trillions; percent

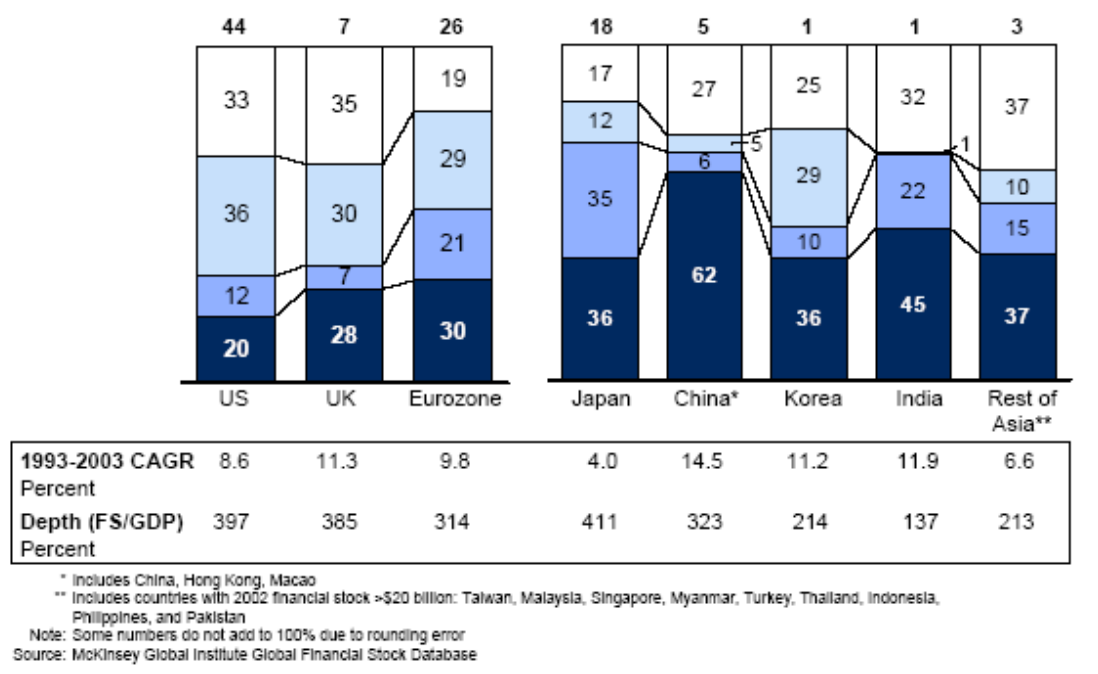


Exhibit 7

Comparative Financing as a Percent of GDP - US vs. Asia Ex-Japan 2004

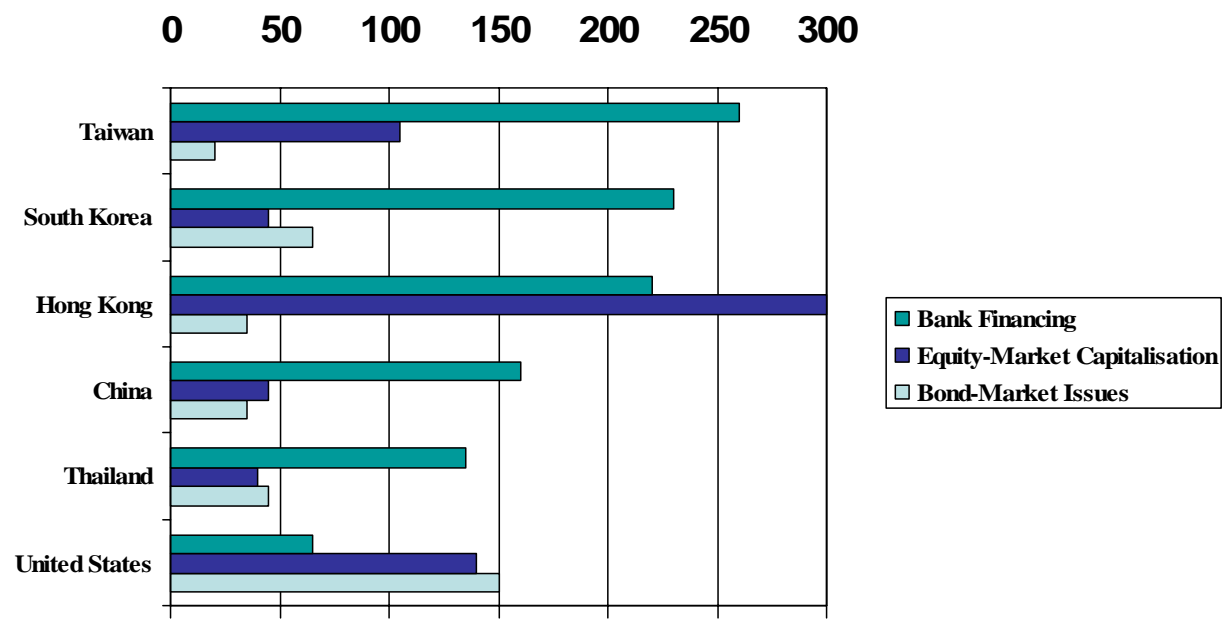

Sources: FIBV; CEIC; Bloomberg; central banks; government statistics

Exhibit 8

Growth in Global AUM by Investor Segment
CAGR*

2004-2009

(\%)

4.3

6.6

5.7

4.3

$-0.3$

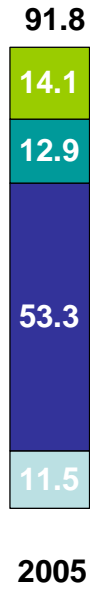

2005
105.3

17.6

15.5

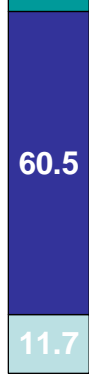

2009 
Exhibit 9

Organization of the Asset Management Industry

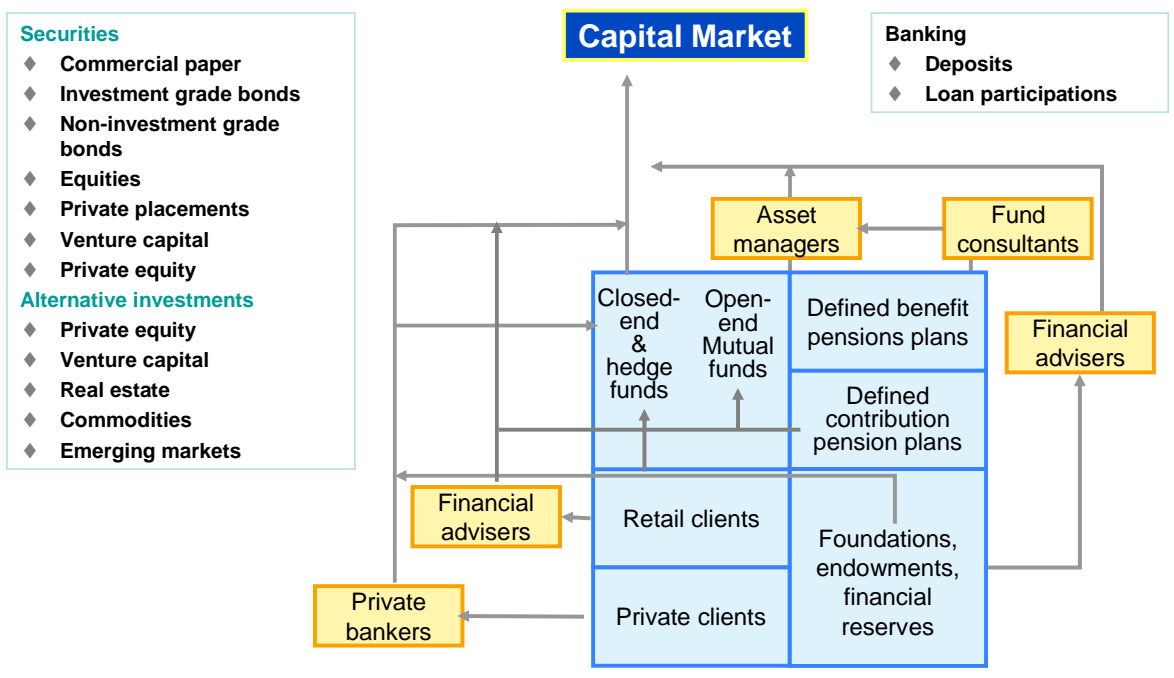

Exhibit 10

Owners of Asset Managers, 2005 (\%)

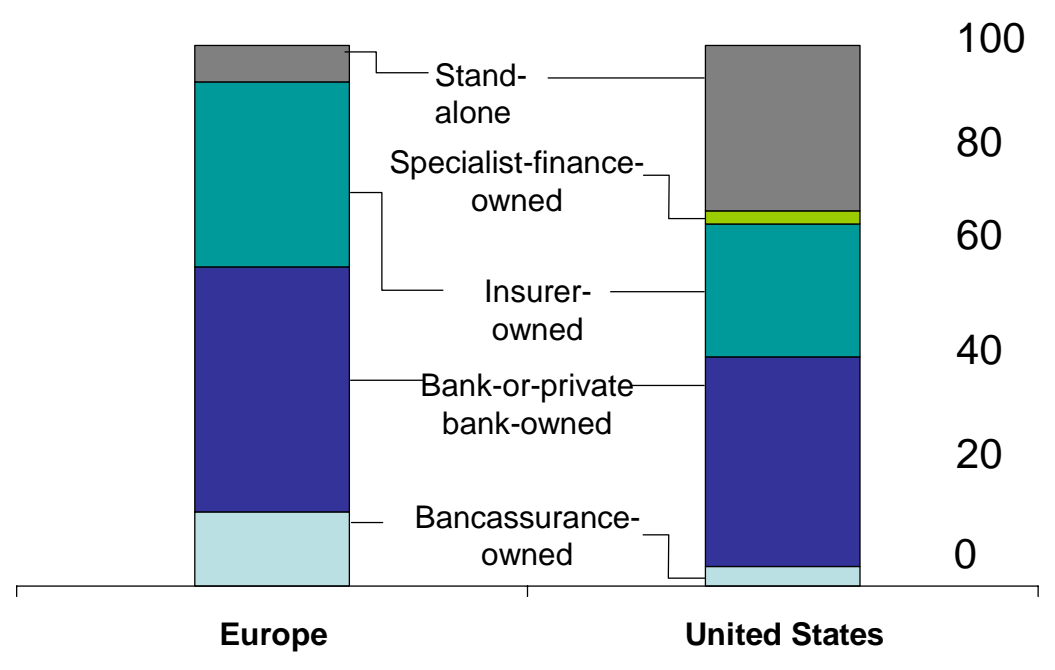

Source: Oliver, Wyman \& Company 


\section{Exhibit 11}

Mutual Funds as a Percentage of Household Financial Assets*

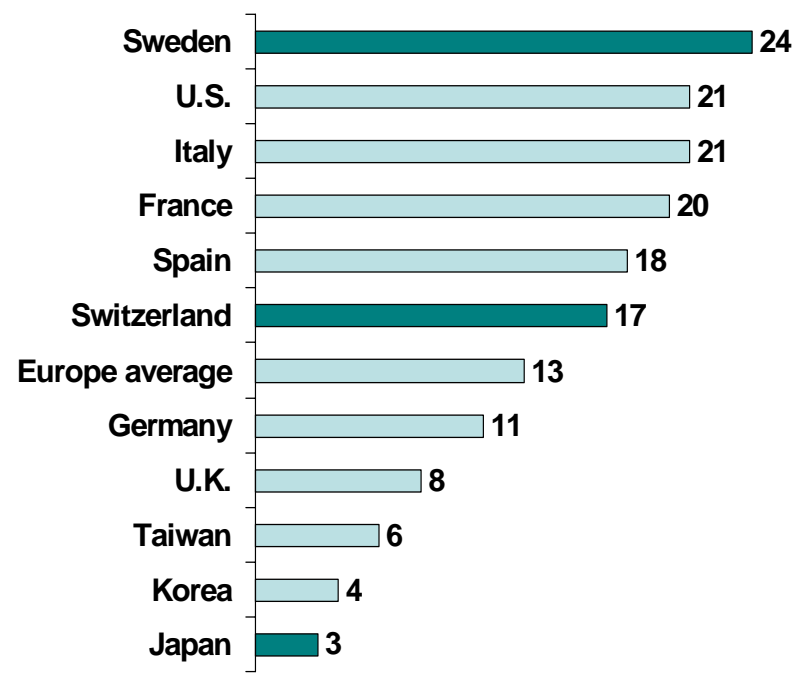

* Most recent data for 2002 and include March 2003 data and estimates. HHFA data typically has a 6-12 month time lag.

Sources: Cerulli Associates; central banks; FEFSI; Strategic Insight; Europerformance; industry trade associations; FERI Fund Market Information

\section{Exhibit 12}

Hedge Funds' Assets Under Management, \$bn

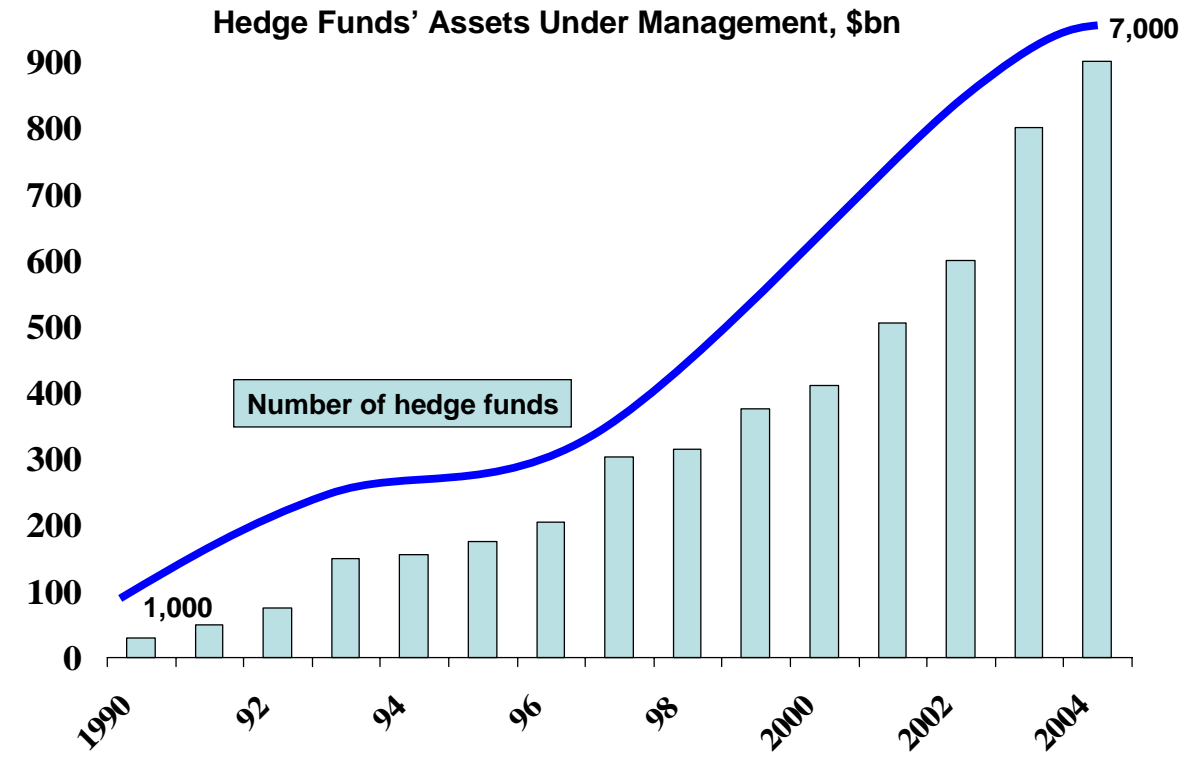

Source: TASS Research, 2004 
Exhibit 13

Mutual Funds in Malaysia

Overall Status of Unit Trust Industry

\begin{tabular}{|l|r|r|}
\hline No. of funds approved & 2004 & 2003 \\
\hline$\quad$ Conventional & 291 & 226 \\
\hline$\quad$ Islamic-based & 220 & 171 \\
\hline Total approved fund size (billion units) & 71 & 55 \\
\hline Units in circulation (billion units) & 218.05 & 174.84 \\
\hline No. of accounts (million) & 118.63 & $97.67^{*}$ \\
\hline Total NAV (RM billion) & 10.43 & $10.30^{*}$ \\
\hline$-\quad$ Conventional (RM billion) & 87.39 & $70.17^{*}$ \\
\hline - Islamic-based (RM billion) & 80.63 & 65.42 \\
\hline \% of NAV to Bursa Malaysia market capitalisation & 6.76 & 4.75 \\
\hline
\end{tabular}

Note: * Figures for 2003 have been readjusted.

Source: Securities Commission Annual Report 2004

Exhibit 14

Asset Allocation in Malaysia

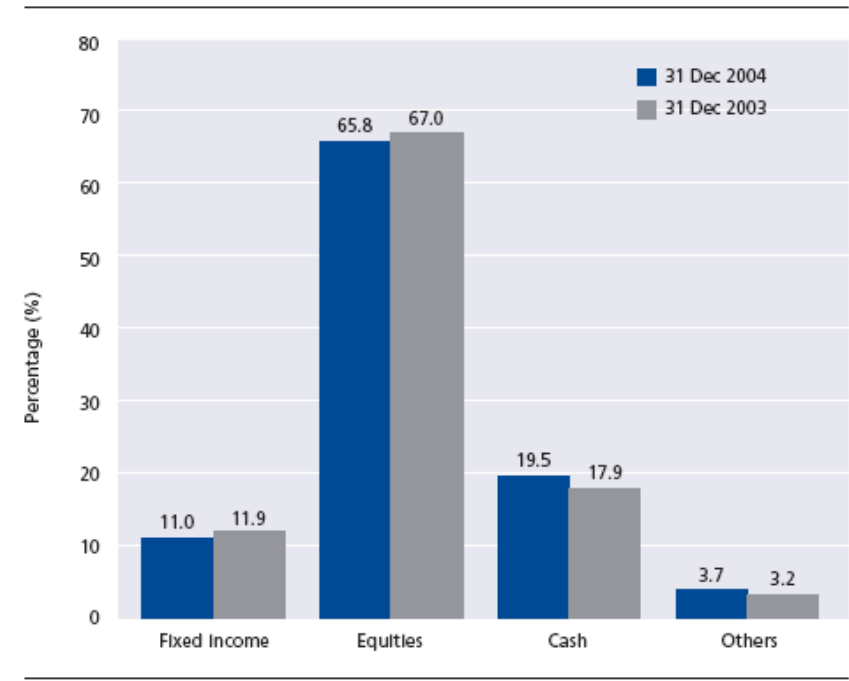

Source: Securities Commission Annual Report 2004 


\section{Exhibit 15}

\section{Thailand Mutual Funds}

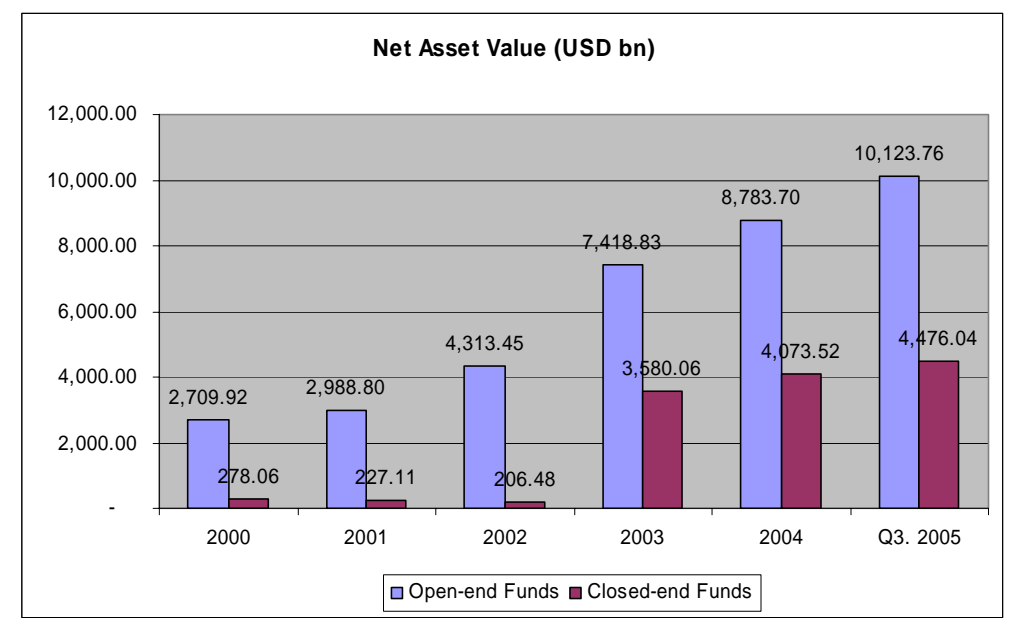

Source : Investment Management Supervision Department, SEC, Thailand

Exhibit 16

Types of Funds, Korea

\begin{tabular}{|c|c|c|c|c|c|}
\hline & Equity & Hybrid & Bond & MMF & Others \\
\hline 2000 & 4062 & 46389 & 56225 & 26805 & 0 \\
\hline 2001 & 6623 & 41566 & 63977 & 35402 & 0 \\
\hline 2002 & 9319 & 45218 & 60031 & 49482 & 0 \\
\hline 2003 & 8316 & 32075 & 52658 & 42052 & 0 \\
\hline 2004 & 7454 & 30703 & 74583 & 59801 & 7762 \\
\hline \multirow[t]{3}{*}{2005.11} & 20422 & 34460 & 50794 & 67271 & 18238 \\
\hline & \multicolumn{4}{|c|}{ Corporate Type } & \\
\hline & Equity & Hybrid & Bond & Others & \\
\hline 2000 & 13 & 4786 & 15 & 0 & \\
\hline 2001 & 296 & 6982 & 190 & 0 & \\
\hline 2002 & 1164 & 7399 & 1561 & 0 & \\
\hline 2003 & 1085 & 7115 & 1736 & 0 & \\
\hline 2004 & 1097 & 3849 & 1304 & 438 & \\
\hline 2005.11 & 1946 & 7505 & 729 & 559 & \\
\hline
\end{tabular}

Source: AMAK 
Exhibit 17

Investment of Funds by Instruments - Singapore

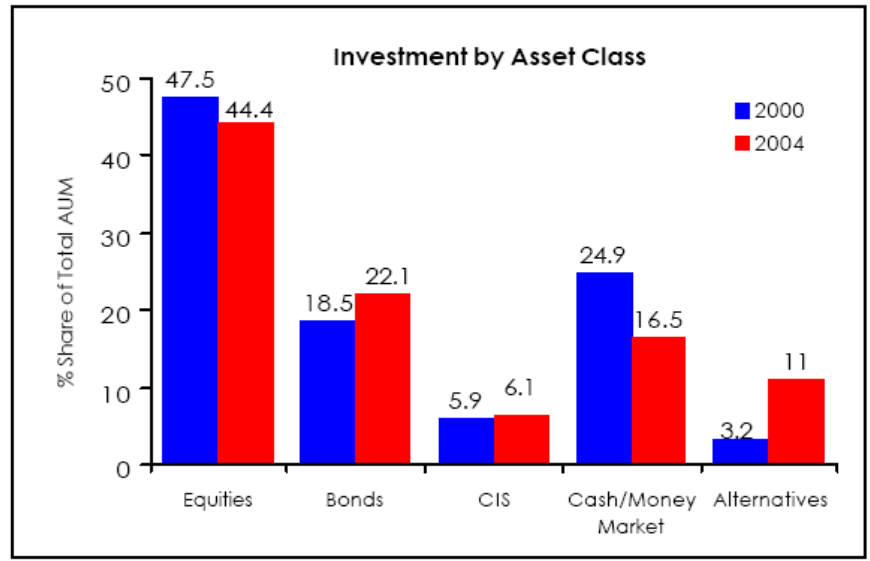

Source: 2004 Singapore Asset Management Survey

Exhibit 18

Asset Allocation of Mutual Funds in Asia - Summary

\begin{tabular}{|l|l|l|l|}
\hline & Equity & Bond & Money Market \\
\hline China & & Significant & Dominate \\
\hline Indonesia & & Dominate & Dominate \\
\hline Korea & & Dominate & Significant \\
\hline Philippines & & & Significant \\
\hline Singapore & Dominate & Dominate & \\
\hline Thailand & & Dominate & \\
\hline
\end{tabular}


Exhibit 19

Internationalization of Mutual Funds in Asia

\begin{tabular}{|l|l|l|}
\hline China & Foreign Funds Listed & Investment in Offshore \\
\hline Indonesia & $\begin{array}{l}\text { Joint ventures (1991) } \\
\text { Sales to foreign companies (up to } \\
49 \%)\end{array}$ & \\
\hline Korea & No restrictions & $\begin{array}{l}\text { Less than 15 percent of the } \\
\text { NAV }\end{array}$ \\
\hline Malaysia & Subject to SC approval & No restrictions \\
\hline Philippines & $\begin{array}{l}\text { Legislation proposed to remove } \\
\text { restrictions }\end{array}$ & $\begin{array}{l}\text { Up to } 20 \text { percent } \\
\text { Prior approval from the central } \\
\text { bank }\end{array}$ \\
\hline Singapore & No restrictions & No restrictions \\
\hline Thailand & \multicolumn{2}{|l}{} \\
\hline
\end{tabular}

Exhibit 20

Formal Reviews of Pension Fund Managers

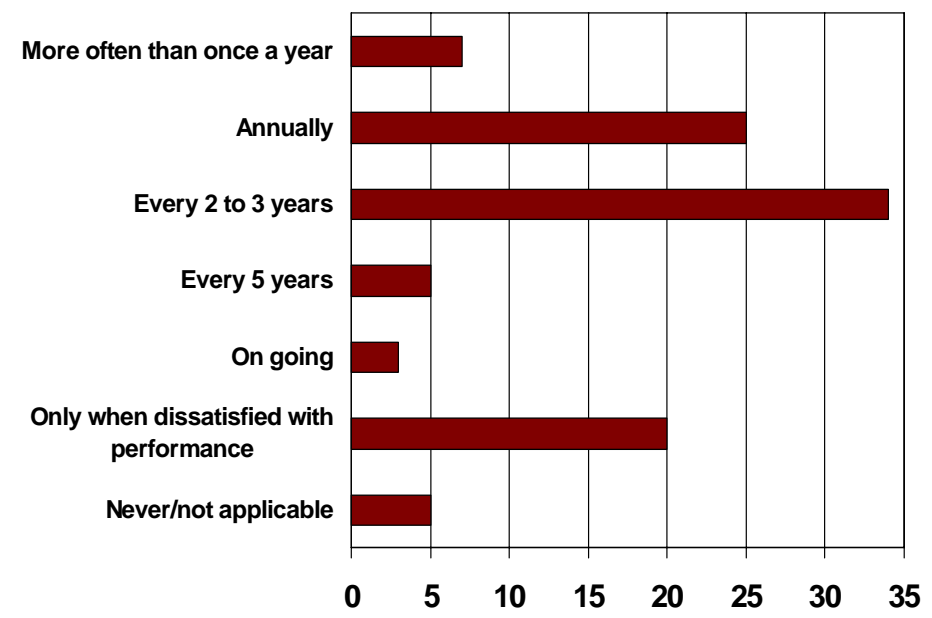

Source: Financial Times, March 17, 2004 
Exhibit 21

Pension Funds in Asia

\begin{tabular}{|l|l|l|}
\hline & Public & Private \\
\hline China & Social Security Fund & Enterprise Annuity Plan \\
\hline Indonesia & Jamsostek, Taspen & $\begin{array}{l}\text { Employer Pension Funds, Financial } \\
\text { Institution Pension Funds }\end{array}$ \\
\hline Korea & National Pension Scheme & Existent, information na \\
\hline Malaysia & Employee Provident Fund & Existent, but very small \\
\hline Singapore & Central Provident Fund & none \\
\hline Thailand & $\begin{array}{l}\text { Social Welfare Fund, } \\
\text { Government Pension Fund }\end{array}$ & $\begin{array}{l}\text { Provident Funds, Retirement Mutual } \\
\text { Funds }\end{array}$ \\
\hline
\end{tabular}

Exhibit 22

Asset Allocation of Public Pension Funds in Asia

\begin{tabular}{|l|l|l|l|l|}
\hline & Equity & Bonds & $\begin{array}{l}\text { Bank } \\
\text { Deposits }\end{array}$ & $\begin{array}{l}\text { Government } \\
\text { Bonds }\end{array}$ \\
\hline China & & & Dominant & Significant \\
\hline Indonesia & & & & \\
\hline Korea & & Dominant & & \\
\hline Malaysia & Significant & Dominant & & Dominant \\
\hline Singapore & & & & \\
\hline Thailand & & Dominant & & Dominant \\
\hline
\end{tabular}


Exhibit 23

Malaysia Pension Asset Allocation, 2004 vs. 1990

1990

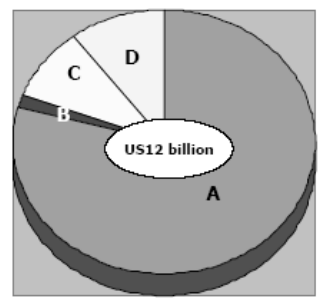

A Malaysian Government Securities - $79.2 \%$ B Equity - 1.6\%

C Loan \& Debenture $-8.8 \%$

D Fixed Income - 10.4\%

\section{4}

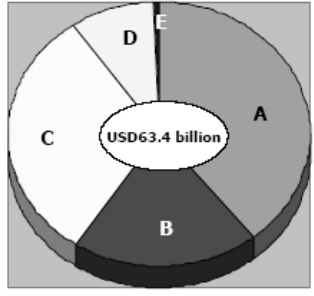

A Malaysian Government Securities - $39.03 \%$

B Equity - $20.00 \%$

C Loans \& Bonds - $31.38 \%$

D Money Market Instruments - $8.96 \%$

E Property-0.63\%

Source: OECD / IOPS Conference on Private Pension in Asia

Exhibit 24

Malaysia: Funds Outsourced to External Managers

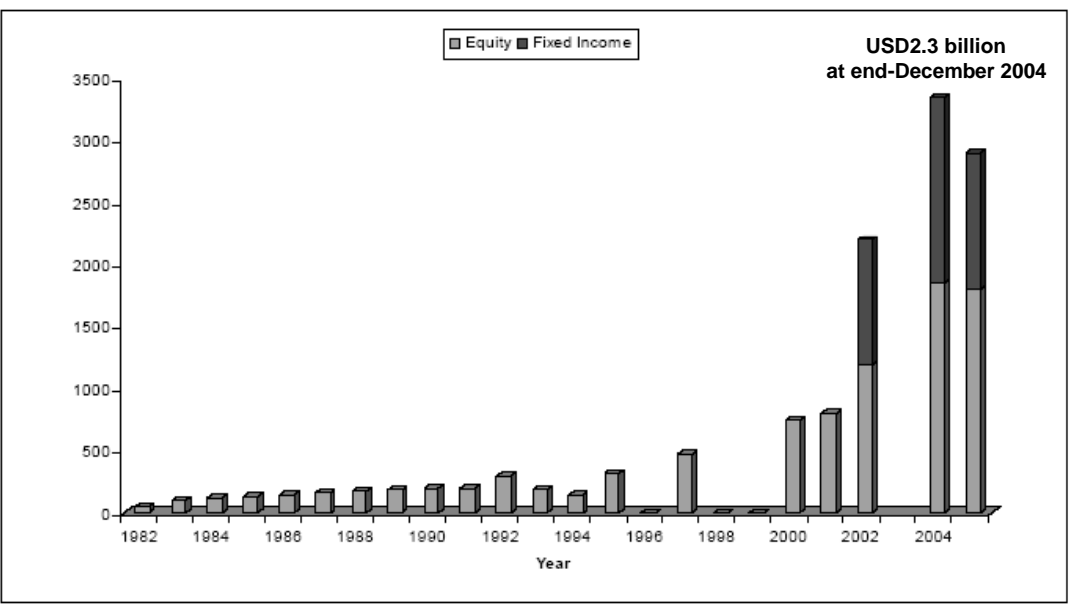

Source: OECD / IOPS Conference on Private Pension in Asia 
Estimated Global Growth in Private Client Assets Under Management

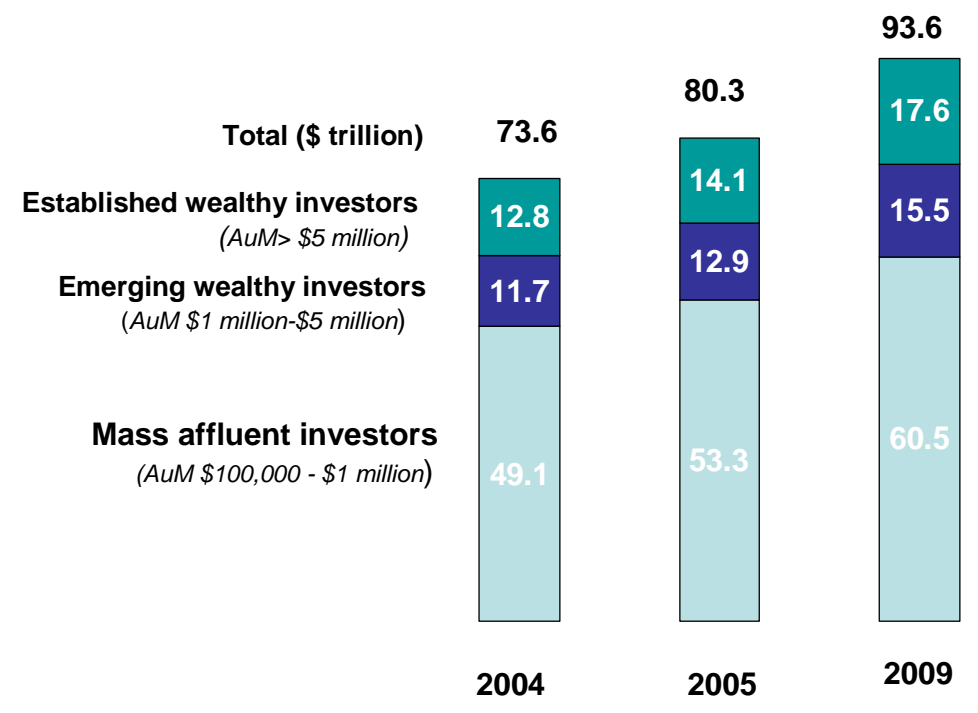

Source: Boston Consulting Group, 2005

\section{Exhibit 26}

Growth in Global AUM by Geographic Market (invested assets \$ trn)

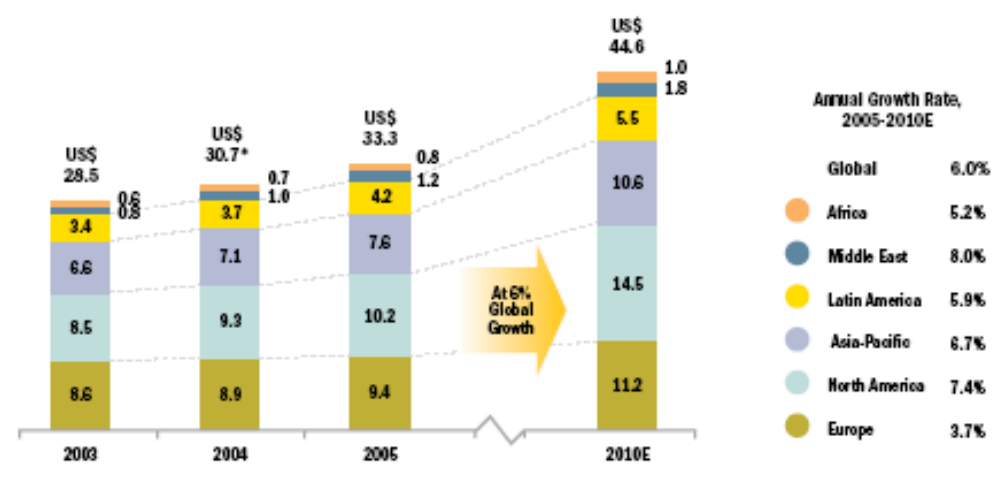

- 2004 numbers have been rifhed and minmally restated, as every year more socurate and recent dass or sources of Ifformatton are gathered.

Nbte: All chart numbers are rounded.

Souroe: Coppenin Lorence curve andigata, 2006 


\section{Exhibit 27}

Fighn

Private Client Assets Under Management by Asset Class

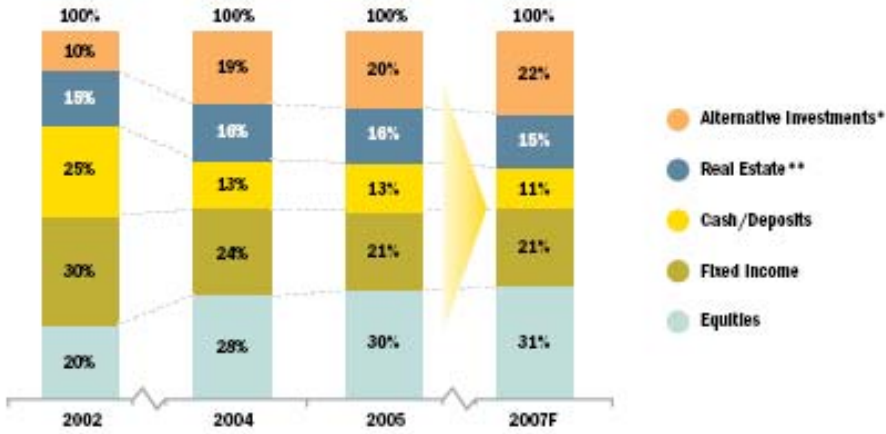

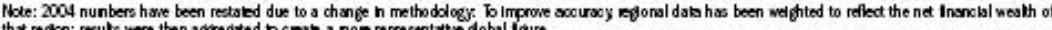
entathe fobstigure

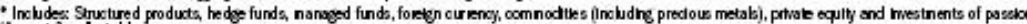

" Inoluder: Ciroct nolectat Imvetments and RETS

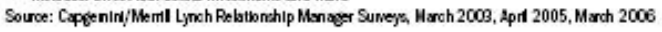

Exhibit 28

Offshore vs. Onshore HNWI Wealth Worldwide

(\$ trillion)

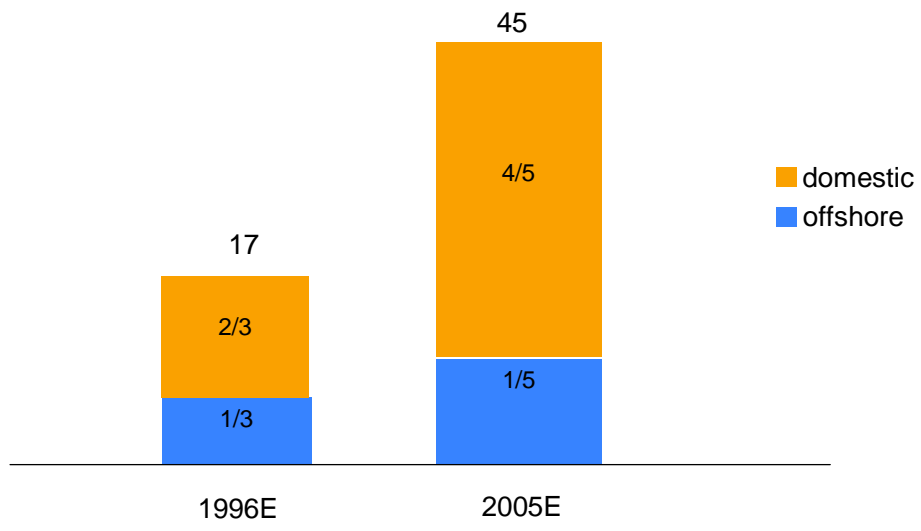

Source: Source: McKinsey \& Co., 2005 


\section{Exhibit 29}

\section{Offshore Private Banking}

Drivers of Offshore Private Banking:

- Tax avoidance/evasion

- Macro-risk and capital flight

- Micro-risk and legal claims on assets

- Personal and family confidentiality

- Business confidentiality

- Multi-residence or travel-related client profiles

- Insider dealing

- Official corruption

- Criminal activity (organized crime, trafficking in drugs and arms

- Other illegal activities requiring money laundering

Competitive Resources in Offshore Private Banking Centers Statutory confidentiality

History and tradition

Regulatory forbearance

Institutional discretion and competence

Regulatory forbearance

Political \& economic stability

Currency convertibility and stability

Tax environment for non-residents

Vulnerability to foreign pressure for disclosure

\section{Exhibit 30}

Estimated Destination of Offshore Private Assets, 2004

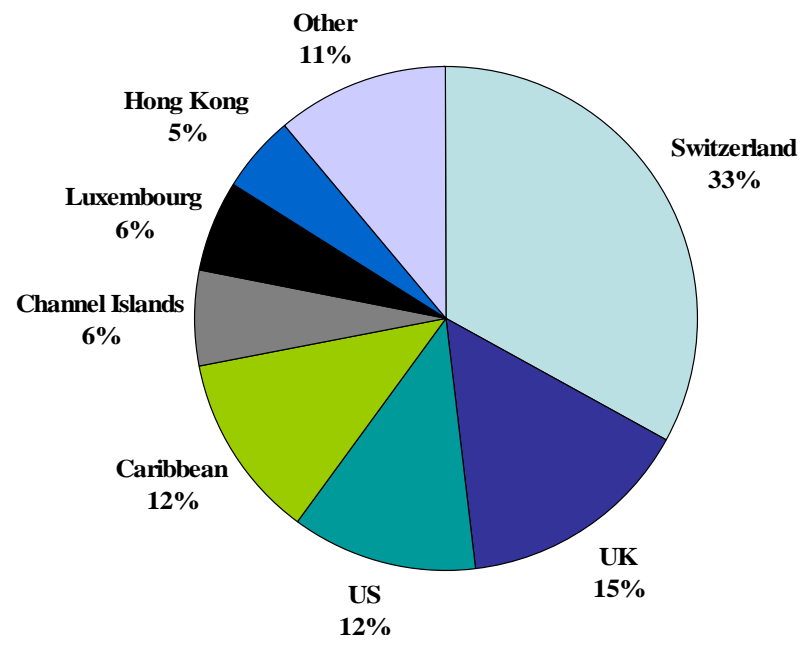

Source: Chase Manhattan Private Bank, Financial Times, CapGemini 
Exhibit 31

The Value Chain in Private Client Asset Management

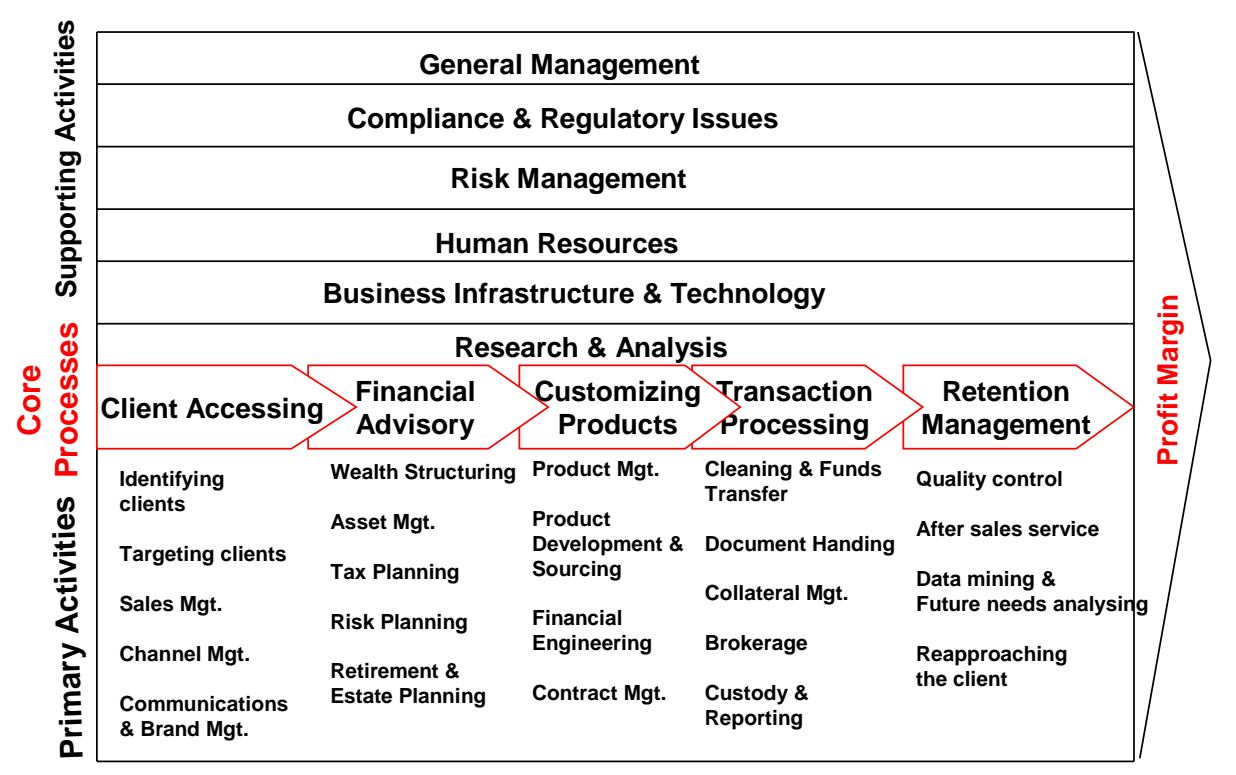

Source: Swiss Banking School, 2005

Exhibit 32

Hong Kong AUM in 2004

Assets under management

- licensed corporations

- registered institutions

Funds/Portfolios on which advice was given - licensed corporations

\$ billion

Other private banking activities

- registered institutions

Combined fund management business 
Exhibit 33

Hong Kong AUM by Type and by Institution in 2004 (HK\$ million)

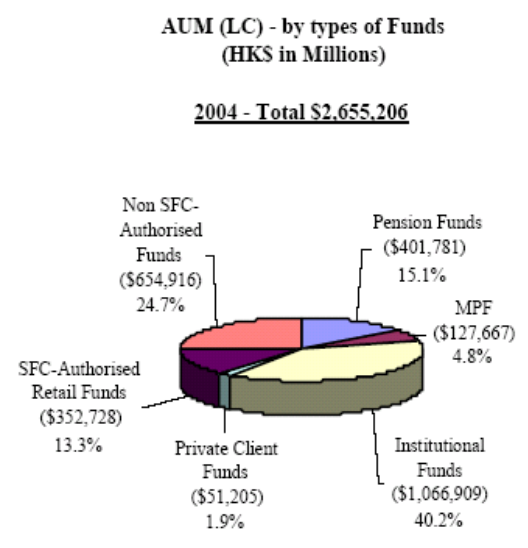

Registered Institutions
AUM (RI) - by types of Funds (HKS in Millions)

$\underline{2004 \text { - Total } \$ 86.241}$

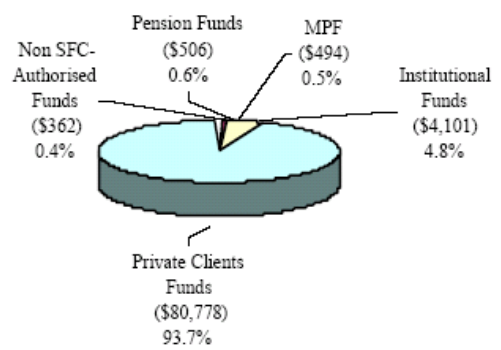

Licensed Institutions

Exhibit 34

Hong Kong AUM by Source of Funds in 2004

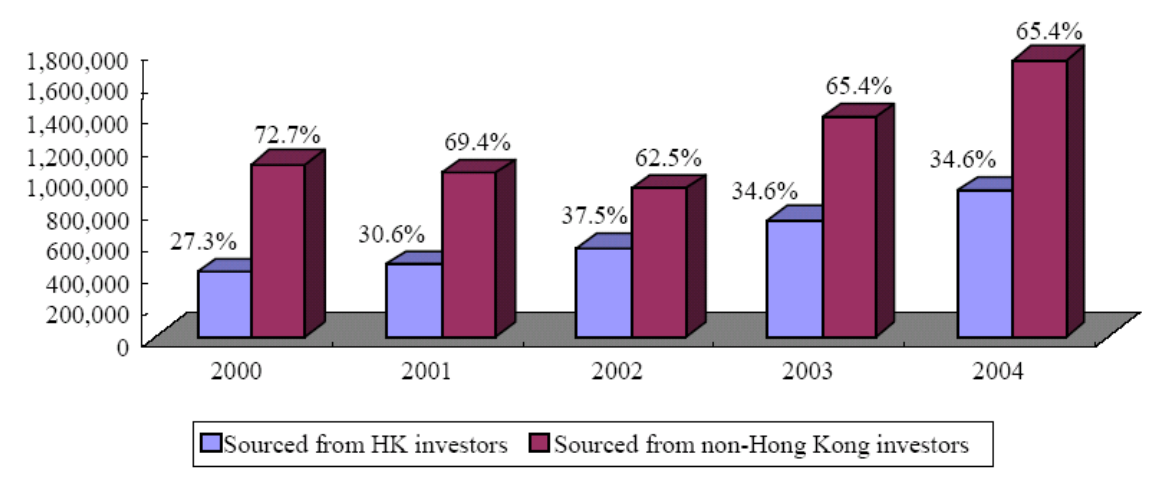


Exhibit 35

Hong Kong AUM by Asset Allocation in 2004 (HK\$ million)

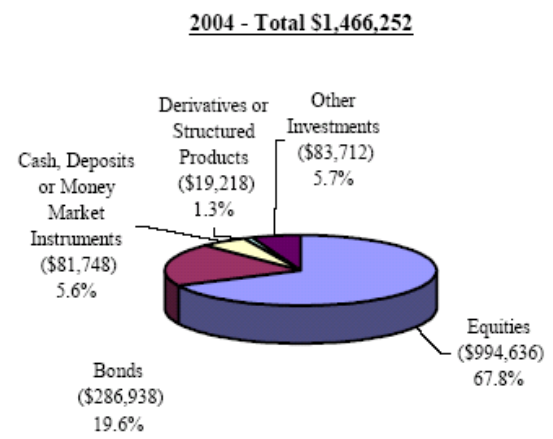

Exhibit 36

Hong Kong AUM by Asset Allocation in 2004

(HK\$ million)

$\underline{\text { Total } \$ 240.942}$

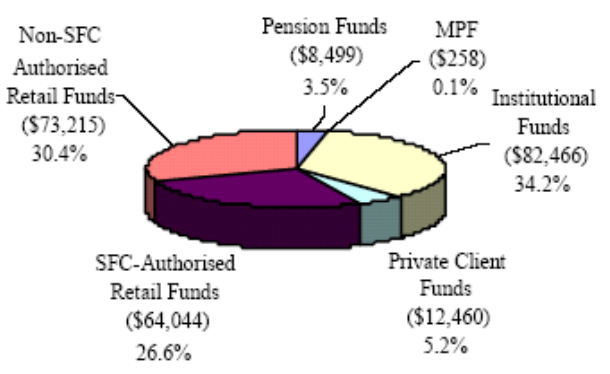


Exhibit 37

Singapore AUM Growth by Type 2000-2004

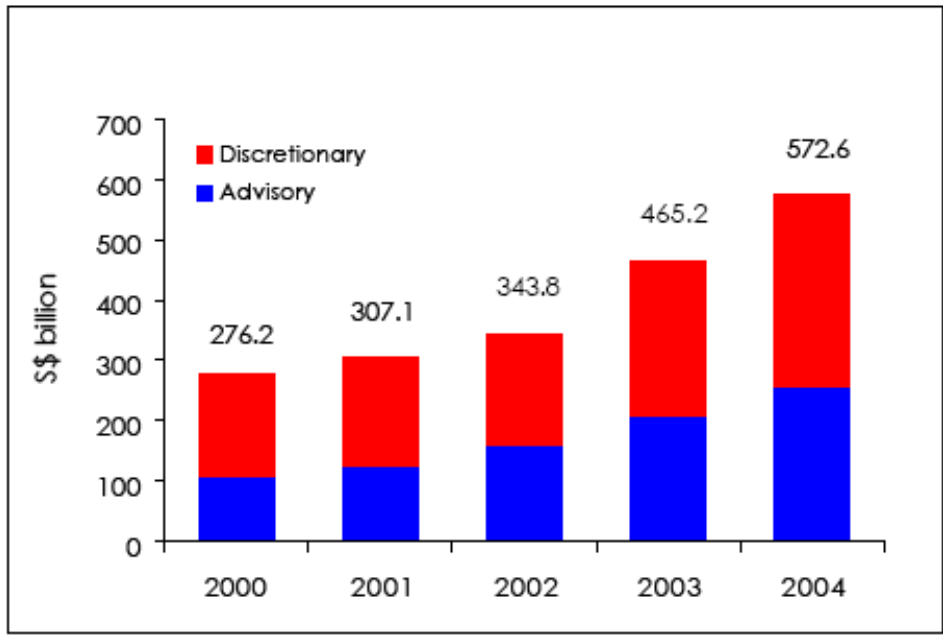

Source: 2004 Survey of the Singapore Asset Management Industry

Exhibit 38

Singapore AUM by Source, 2004

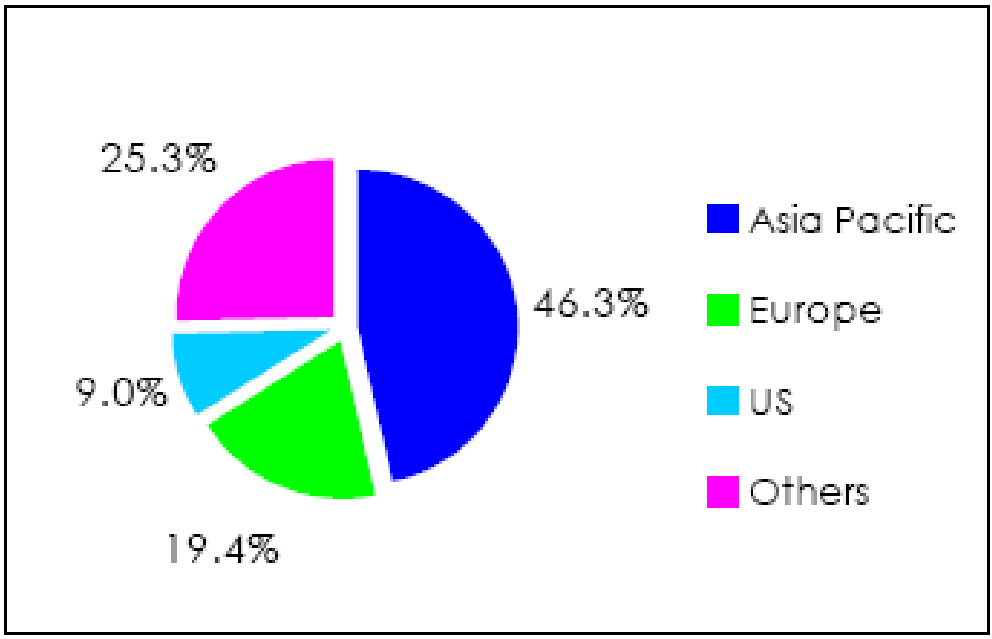

Source: Singapore MAS, 2005 
Exhibit 39

Stardard \& Poor's Financial Transparency Ratings, 2005

$\begin{array}{llll}\text { UK } & 8 & \text { China } & 5 \\ \text { US } & 8 & \text { Hong Kong } & 5 \\ \text { Sweden } & 7 & \text { Thailand } & 5 \\ \text { France } & 6 & \text { Korea } & 5 \\ \text { Japan } & 6 & \text { Malaysia } & 5 \\ \text { Germany } & 5 & \text { Indonesia } & 4 \\ \text { Italy } & 5 & \text { Philippines } & 3 \\ \text { Spain } & 5 & \text { Taiwan } & 2 \\ \text { Switzerland } & 5 & & \end{array}$

Standard \& Poor's study of corporate transparency based on 98 pieces of information Divided into (1) Owbership structure and investor relations, (2) Financial transparency And information disclosure, and (3) Board management structure and process. Companies Ranked in deciles and average deciles compared across countries. Source: S\&P, 2002.-

Exhibit 40

Quality of Financial Transparency, 2004

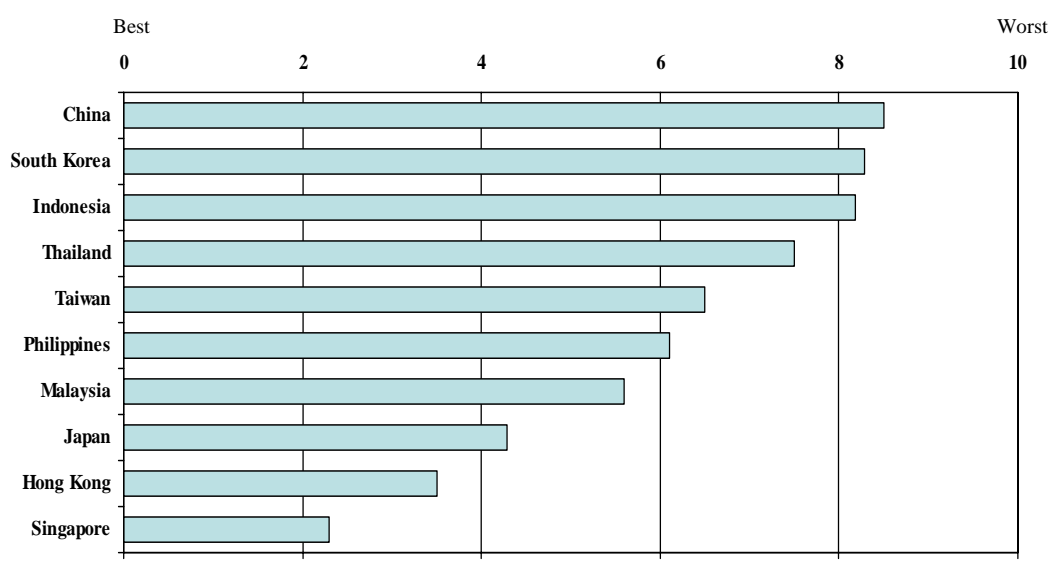

Grades range from 0 to 10 , with 0 being the best and 10 the worst

Source: Political and Economic Risk Consultancy, 2005. 
Exhibit 41

Quality of Corporate Governance, 2004

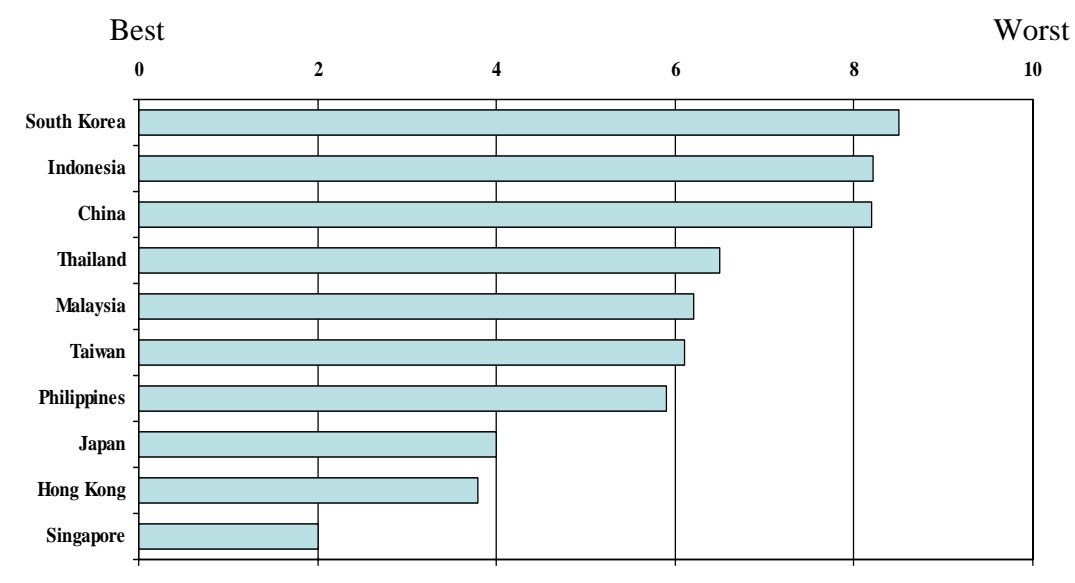

Grades range from 0 to 10 , with 0 being the best and 10 the worst Source: Political and Economic Risk Consultancy 